\title{
Rat models of human diseases and related phenotypes: a systematic inventory of the causative genes
}

\author{
Claude Szpirer ${ }^{1,2}$ (D)
}

\begin{abstract}
The laboratory rat has been used for a long time as the model of choice in several biomedical disciplines. Numerous inbred strains have been isolated, displaying a wide range of phenotypes and providing many models of human traits and diseases. Rat genome mapping and genomics was considerably developed in the last decades. The availability of these resources has stimulated numerous studies aimed at discovering causal disease genes by positional identification. Numerous rat genes have now been identified that underlie monogenic or complex diseases and remarkably, these results have been translated to the human in a significant proportion of cases, leading to the identification of novel human disease susceptibility genes, helping in studying the mechanisms underlying the pathological abnormalities and also suggesting new therapeutic approaches. In addition, reverse genetic tools have been developed. Several genome-editing methods were introduced to generate targeted mutations in genes the function of which could be clarified in this manner [generally these are knockout mutations]. Furthermore, even when the human gene causing a disease had been identified without resorting to a rat model, mutated rat strains (in particular KO strains) were created to analyze the gene function and the disease pathogenesis. Today, over 350 rat genes have been identified as underlying diseases or playing a key role in critical biological processes that are altered in diseases, thereby providing a rich resource of disease models. This article is an update of the progress made in this research and provides the reader with an inventory of these disease genes, a significant number of which have similar effects in rat and humans.
\end{abstract}

Keywords: Rat, Disease, Genes, Animal models

\section{Background}

Why map and identify genes for rat disease phenotypes or related traits? As already pointed out, the laboratory rat (Rattus norvegicus) is more than a big mouse. The mouse is a species which has been the mammalian genetic model of choice for a long time, with an initial focus on monogenic traits. Rat models of monogenic traits and diseases have also been isolated but the rat has essentially been a key model for studies of complex traits in fields such as physiology, cardiovascular and diabetes

Correspondence: cszpirer@gmail.com

'Université Libre de Bruxelles, B-6041 Gosselies, Belgium

${ }^{2}$ Waterloo, Belgium

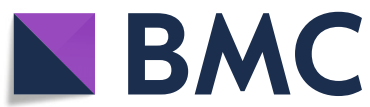

research, arthritis, pharmacology, toxicology, oncology and neurosciences [1-6]. In some situations the rat seems to be a more relevant or faithful model. For instance, the physiology of the rat is extremely well documented, in part because its larger body size affords the opportunity for serial blood draws, which are almost impossible in the mouse; in cardiovascular research [7], sophisticated surgical manipulations, and physiological measurements such as blood pressure measurements by telemetry are easier to perform and more reliable in rats compared to mice $[1,3]$. The rat has also long been a common choice for pharmacology and toxicology studies because it shares a similar pathway with humans for eradicating toxins

(c) The Author(s). 2020 Open Access This article is licensed under a Creative Commons Attribution 4.0 International License, which permits use, sharing, adaptation, distribution and reproduction in any medium or format, as long as you give appropriate credit to the original author(s) and the source, provide a link to the Creative Commons licence, and indicate if changes were made. The images or other third party material in this article are included in the article's Creative Commons licence, unless indicated otherwise in a credit line to the material. If material is not included in the article's Creative Commons licence and your intended use is not permitted by statutory regulation or exceeds the permitted use, you will need to obtain permission directly from the copyright holder. To view a copy of this licence, visit http://creativecommons.org/licenses/by/4.0/ The Creative Commons Public Domain Dedication waiver (http://creativecommons.org/publicdomain/zero/1.0/) applies to the data made available in this article, unless otherwise stated in a credit line to the data. 
[8]. With respect to cancer research $[9,10]$, and more precisely mammary cancer research, it is noteworthy that rat and human carcinomas show similar development and histopathological features [11, 12]; furthermore, rat mammary tumors are strongly hormone dependent for both induction and growth, thus resembling human breast tumors and no virus appears to be involved in rat and human mammary carcinogenesis, unlike mouse mammary carcinogenesis the etiological agent of which is the mouse mammary tumor virus. As stated by Russo "The rat mammary tumor model is well suited for studying in situ and invasive lesions [...]. The classification of the tumors matches well with the criteria used in the human pathology, and provides an adequate model for understanding these phases of the human disease" [11]. In addition, there is extensive overlap between human breast and rat mammary cancer susceptibility genomic regions and "the laboratory rat will continue to be an important model organism for researching genetically determined mechanisms of mammary cancer susceptibility that may translate directly to human susceptibility" [13]. In neuroscience research, rats have significant anatomical and behavioral advantages over mice, because they are more sociable and skilled and have complex cognitive abilities; this wider range of social behaviors and a richer acoustic communication system confer the rat advantages in comparison to mouse models to study neuro-developmental disorders and in particular autism $[14,15]$. The rat thus provides one with particularly reliable models of human traits or diseases $[3,8,11-17]$ (multiple details emphasizing the value of rat models can be found in these articles).

Numerous rat strains have been created by selective breeding of animals expressing a desired phenotype, generating a very large collection of genetic models of pathological complex, polygenic traits, most of which are quantitative. Interestingly, these strains also provide one with additional phenotypes, which were not selected for. Just as the traits that were selected for, most of these phenotypes are polygenic. All these phenotypes can be used as models of human traits or diseases [18], implying that the genes underlying these traits or diseases should be identified. Information on rat strains and rat disease models, can be found at the Rat Genome Database (RGD, https://rgd.mcw.edu/) [19].

In order to give the rat the status of a valuable genetic model, and in particular to identify the genes underlying complex traits by forward genetic approaches and to analyze the relevant biological mechanisms, several tools had to be developed. This has been accomplished. Genetic and chromosome maps have been developed; the genomic sequence of dozens of rat strains has been established; a number of resources have been created to provide investigators with access to genetic, genomic, phenotype and disease-relevant data as well as software tools necessary for their research $[3,20]$. Thanks to these resources, positional identification of numerous rat genes underlying monogenic or complex diseases and related traits could be achieved. On the other hand, reverse genetic tools have also been developed. Efficient methods to generate mutant rats became available; sperm N-ethyl-N-nitrosourea (ENU) mutagenesis followed by gene-targeted screening methods lead to the isolation of several mutants, including knockout (KO) strains ([21] and references therein). Rat ES were successfully derived and could be used for targeted mutations by homologous recombination; more importantly, several methods not relying on the use of ES cells were introduced to generated targeted mutations (often these are $\mathrm{KO}$ mutations), namely gene editing by zinc finger nucleases, by transcription activator-like effector nucleases and finally by the clustered regularly interspaced short palindromic repeat (CRISPR/Cas) system [22]. Transgenic rats can also be generated, including humanized rats carrying large chromosomic fragments ("transchromosomic humanized" rats) [23]. Development of these technologies provides the researcher with all the tools required to take advantage of the unique opportunities offered by the rat as leading model for studies different areas of biomedical research $[3,17]$. In this review I made an inventory of the rat genes identified as responsible for monogenic or polygenic diseases and related traits. I took into account the rat genes identified by forward genetic methods as well as those inactivated by ENU-mutagenesis and by targeted mutations, the inactivation of which generated a disease or an abnormal phenotype. This update of the progress made in the identification of rat disease genes shows that a considerable number of conserved genes have similar effects on biological traits in rats and humans, establishing the rat as a valuable model in studies of the genetic basis of human diseases and thus providing one with a useful resource of disease models.

\section{Materials and methods}

The data (causal genes of rat diseases and related traits) were collected by regular and systematic screening of the biomedical literature, PubMed searches (https:// www.ncbi.nlm.nih.gov/) and regular Google Scholar alerts based on the keywords "knockout", "mutation", "rat" (spread over several months). In addition, relevant data were retrieved from the RGD ("Disease Portals"), with advices from Jennifer R. Smith. Genes identified by forward genetic means (or by direct molecular sequencing) were considered as suggestive, solid or confirmed, respectively, as indicated in each case in Table 1 (one, two or three asterisks), on the basis of the criterions described in the legend to the table; these criterions are based on the standards discussed by Glazier and coworkers [24]. With respect to the induced mutants, they were included provided they were convincingly shown to 
be specifically altered. The official gene symbols are used in this article and were obtained from the National Center for Biotechnology Information (https://www.ncbi.nlm.nih.gov/), Gene section. In several instances the original publications did not use the official gene symbol; in these cases, the nonofficial symbol is indicated in parenthesis in the footnote to the table, where the full name of each gene is described. The position of every gene was also obtained from the NCBI.

\section{Results}

The core of this article is a list of the diseases and related traits or phenotypes the causal gene of which was identified in the rat (Table 1). The genes identified by forward genetic methods or, in a few instances, by direct molecular characterization are labeled by asterisks (see legend to table). Also listed are the phenotypes uncovered by reverse genetics methods, either by ENU-mutagenesis followed by selection of the desired mutated gene (these genes are labeled by the symbol ${ }^{\mathrm{ENU}}$ ), or by targeted gene editing (these genes are labeled by ${ }^{\mathrm{T}}$ ). Table $1 \mathrm{~A}$ shows the monogenic traits, and Table 1B the complex traits (in a few cases this distinction is somewhat arbitrary, but in general this is a useful classification). Of note, when a gene was associated with several distinct phenotypes, an entry was created for each phenotype and the gene thus appears several times in the table. When the human homolog gene is known to be causal of the relevant disease or trait, it is also indicated in the table. Furthermore, entries in bold characters indicate that the human gene was found to be causal as a direct translation of the results obtained in the rat.

\section{Identification of rat disease genes by forward genetic methods}

The identification of gene(s) underlying a given phenotype typically starts with the mapping of the trait by linkage analysis (backcrosses, intercrosses). In the case of monogenic traits, this approach is generally sufficient to identify the causative gene (positional identification, as illustrated in Table 1A). Identifying genes controlling complex traits is much more difficult [24, 25]; indeed, linkage analyses of such traits lead to the localization of quantitative trait loci (QTLs), which are too large to allow the identification of the causative gene. Complementary strategies are thus required to narrow down the list of candidate genes, such as the generation of congenic lines or/and the use of integrative genomic approaches (as discussed in [26]). Alternative approaches rely on the use of panels of lines that show a higher level of recombinant events, as a result of crossing parental strains for multiple generations, such as recombinant inbred strains or heterogeneous stocks (as discussed in [27], for a striking harvest of results derived from the study of a heterogeneous stock, see [28]). The first complex-trait gene identified is the $C d 36$ gene, which causes insulin resistance, hyperlipidemia and hypertension in the spontaneously hypertensive rat (SHR) $[29,30]$. This identification was based on a combined gene expression micro-array and linkage approach and was definitively proven by in vivo complementation, i.e. transgenic expression of normal Cd36 in the SHR [31]. Last but not least, association was then demonstrated between human CD36 and insulin resistance [32]. Subsequently, the tools of forward genetic studies as well as gene expression and/or computational analysis (integrative genomics) led to the identification of numerous genes underlying rat polygenic traits or diseases, such as blood pressure, cardiac mass, diabetes, inflammation (in particular arthritis, encephalomyelitis), glomerulonephritis, mammary cancer, neurobehavioral traits, proteinuria. In several instances, the results were translated to the human, as illustrated in Table 1 by bold entries. Interestingly, a recently discovered complex trait gene is a long non-coding RNA, itself contained within the 5' UTR of the $R f f l$ gene (Rffl-lnc1); Rffl-lnc1 shows a $19 \mathrm{bp}$ indel polymorphism which is the precise variation underlying regulation of blood pressure and QT-interval. This work was based on fine and systematic congenic mapping and is the first one to identify quantitative trait nucleotides in a long non-coding RNA [33]. The human homologous region, on chromosome 17, has multiple minor alleles that are associated with shorter QT-intervals and, is some cases, hypertension [34].

Identifying rat disease genes is not only useful to discover the homologous human disease genes but also helps in studying the mechanisms underlying the pathological abnormalities. After all, this is the essence of an animal model. For instance, the study of the genetic basis of stroke in the stroke-prone SHR strain (SHRSP) led to the conclusion that mitochondrial dysfunction contributes to stroke susceptibility and to hypertensive target organ damage (such as vascular damage); this better understanding of the etiology of the disease can open the door to novel therapies, as briefly discussed below $[8,35,36]$.

\section{The importance of rat models in the era of human genetic studies and genome sequencing}

The rat is also a useful model to decipher the biological significance of QTLs identified in human genome-wide association studies (GWAS) aimed at understanding the etiology of common human diseases [37, 38]. These studies pint-point human genomic regions controlling a complex trait, and generally contain several genes; the current methods lack the statistical power to pinpoint the human causative gene. Animal model such as the rat provides one with the possibility to knockout or to 
mutate in more subtle manner each of the rat genes homolog to the human genes contained in a given GWAS locus. In this way, the possible role of each gene can be evaluated. For instance, Flister and cocorkers [39], studying a multigene GWAS locus controlling blood pressure and renal phenotypes (AGTRAP-PLOD1 locus) used gene targeting in a rat model to test each of the genes contained in this locus. In this way these authors could show that several genes impact hypertension and that multiple causative gene variants cosegregate at this locus; several linked genes thus control blood pressure (Agtrap, Clcn6, Mthfr, Nppa, Plod1). Furthermore, each of the $\mathrm{KO}$ rat models so generated can be used to dissect the biological effects of the gene loss of function.

The genetic basis of human diseases is also actively analyzed by whole genome sequencing; such studies have uncovered several genes underlying diseases or related phenotypes $[40,41]$ and one can thus questioned the importance of genetic analyses in an animal model. As argued and illustrated above, animal models and the rat in particular, remain valuable tools to analyze the biological mechanisms underlying a phenotype. In addition, transgenesis or gene substitution can also be carried out, in which a human allele can be introduced in the relevant $\mathrm{KO}$ rat, in order to verify the role of the human mutation. Alternatively, the rat genome can be directly modified to specifically introduce a mutation similar to the one causing the human trait $[40,42]$. If the modified rats exhibit defects similar to those observed in the human patients, it can be concluded that the tested human mutation indeed plays a causal role. In addition, similarly to examples mentioned above, such specifically modified rats provide one with models suitable to study the mechanisms responsible for the abnormalities generated by the mutation and also to carry out pharmacological tests and look for possible new therapies [42].

The need of relevant animal models is also illustrated by the fact that even when the human gene causing a disease is known, mutated rat strains (in particular $\mathrm{KO}$ strains) were created to analyze the gene function and the disease pathogenesis (see numerous examples of such gene targetings in Table 1). In 2008, Aitman and coworkers [2] reported a list of 21 rat disease genes (that had been identified by positional cloning). Here I updated the list of rat disease genes; this inventory added numerous genes identified (or deliberately mutated) after 2008, thereby evaluating progress made in the input of rat disease models. The total rat gene number listed in Table 1 exceeds 350 , illustrating the vigor of the rat biomedical research which led to enrichment of numerous disease models, with the translation to humans of disease gene discoveries in rats.

Translation of the rat genetic studies into new treatments of human diseases

The identification of a human disease gene has the potential to develop new therapeutic approaches. For instance, the human gene NCF4 was found to be associated with arthritis as a translation of studies on a rat arthritis model. The gene encodes a component of the NADPH oxidase complex and these studies catalyzed the development of a new therapy for arthritis, based on the use of oxidative-burst inducing substances [43-45] (see Table 1B, Arthritis, Ncf1 gene). Another interesting example is that of the gene SHANK3: mutations in this gene lead to a neurodevelopmental disorder known as Phelan-McDermid syndrome; to date, no pharmaceutical compounds targeting core symptoms of this human disease are available. A Shank3-deficient rat model was generated, which showed disabilities similar to those seen in the Phelan-McDermid syndrome and interestingly, the deficits of the mutant rat could be ameliorated by intracerebroventricular oxytocin administration, implying that exogenous oxytocin administration might have therapeutic potential in human patients [42] (see Table 1A, Phelan-McDermid syndrome model). A third example is provided by the study of rat mutated in the $P d e 3 a$ gene, which recapitulates the phenotype of HTNB (Hypertension with brachydactyly) human patients: the functional data suggest that soluble guanyly cyclase activation could be suitable for the treatment of HTNB patients [46] (See Table 1B, Blood pressure section).

\section{Conclusions}

This evaluation of progress in the identification of genes causing monogenic or polygenic rat diseases or related phenotypes yielded a list containing over 350 genes. In several instances the result obtained in the rat model was translated to the human, demonstrating that a considerable number of conserved genes have similar effects on biological traits in rats and humans, and thus providing one with a rich and useful resource of disease models (Table 1, bold entries). For instance, the Inppl1 gene was first identified in the rat as a causative gene of type 2 diabetes and this discovery led to the identification of mutations in the homolog gene of diabetic patients [452, 534]. Similarly, a rat paralog of the Fcgr3 gene (Fcgr3-rs) was identified as causing glomerulonephritis, and the result was promptly translated to the human: low copy number of FCGR3B, an orthologue of rat Fcgr3, was associated with glomerulonephritis in the autoimmune disease systemic lupus erythematosus [471]. 
Table 1 Alphabetical list of diseases and related traits with their causative rat genes and the human homologs

\begin{tabular}{|c|c|c|c|c|c|}
\hline Rat & & Human & & Comments & References \\
\hline Phenotype & $\begin{array}{l}\text { Causative } \\
\text { gene name }{ }^{a} \\
\text { Localisation }^{c}\end{array}$ & Phenotype & $\begin{array}{l}\text { Ortholog } \\
\text { gene name } \\
\text { Localisation }^{\mathrm{c}}\end{array}$ & & \\
\hline
\end{tabular}

\section{A) Monogenic traits}

Acidosis (pH homeostasis)

\section{Kcnj16 $\quad$ Brugada syndrome KCNJ16}

10, $99.33 \mathrm{Mb}$ (arrhythmias) 17q24.3

\begin{tabular}{|c|c|c|}
\hline Addiction & $\begin{array}{l}\text { Bdnf } \\
3,100.77 \mathrm{Mb}\end{array}$ & - \\
\hline Addiction & $\begin{array}{l}\mathrm{Cdh} 13^{\mathrm{T}} \\
19,50.85 \mathrm{Mb}\end{array}$ & $\begin{array}{l}\text { Substance abuse, } \\
\text { behavioral disorders }\end{array}$ \\
\hline $\begin{array}{l}\text { Addiction: opioid } \\
\text { consumption }\end{array}$ & $\begin{array}{l}\mathrm{Grm} 2^{\top} \\
2 \mathrm{q} 32, \\
179.58 \mathrm{Mb}\end{array}$ & - \\
\hline Adiposity (fat pads) & $\begin{array}{l}\text { S/c22a18** } \\
1,216.67 \mathrm{Mb}\end{array}$ & - \\
\hline
\end{tabular}

Aganglionosis (spotting Ednrb** lethal: $s$ 15q22, $88.00 \mathrm{Mb}$
The SS KO mutant exhibits hyperventilation at rest and decreased arterial $\mathrm{pH}$, showing that Kcnj16 plays a role in $\mathrm{pH}$ regulation, particularly in the ventilatory $\mathrm{CO} 2$ chemoreflex; the gene also controls blood pressure: see below, Polygenic traits

The heterozygous SD KO mutant exhibits no cocaine-seeking behavior, unlike WT rats

The SS KO mutant shows a stronger responsiveness to cocaine, metamphetamine and saccharin

The Wistar KO mutant shows higher heroin self-administration and heroin intake as well as reduced sensitivity to cocaine reward; the results suggest that Grm2 may play an inhibitory role in opioid action; see also below, Polygenic traits, Addiction: alcohol consumption

Positional identification revealed a splicing mutation in the SHR/NCrj rat (which shows reduced fat pad weight); in 3 T3-L1 cells, S/c22a18 KO leads to reduction in lipid accumulation

Direct analysis of the gene in $s /$ rats revealed a [53-59] deletion; the mutation was then shown to segregate with the phenotype in congenics; phenotype modulated by modifier genes, including Gdnf; in the GK strain, the null mutant causes embryonic death; see also below, Polygenic traits, Blood pressure: captopril effects

See Macrophage development

Direct sequencing of the gene revealed an insertional mutation in a mutant SHRSP strain; the mutation was then shown to segregate with the phenotype; partial complementation in Sp6 transgenic rats; in the human, SP6 is one the genes causing Amelogenesis imperfecta

Direct cloning of the mutant gene revealed a 7 bp deletion at the splicing donor site in intron $\mathrm{H}$ of the analbuminemic rat, which does not produce cytoplasmic albumin mRNA

Direct sequencing of the Kit cDNA revealed a $12 \mathrm{bp}$ deletion in the Ws/Ws strain, by comparison with the BN and SD sequences: the gene also controls coat color and unilateral renal agenesis: see below

Positional identification of the gene (from Belgrade rats) which shows a missense mutation, inactivating iron transport

The SD KO mutant shows delayed reflex development, motor deficits in rearing and fine motor skills, aberrant social communication, impaired touchscreen learning and memory, decreased brain volume and altered neuroanatomy 
Table 1 Alphabetical list of diseases and related traits with their causative rat genes and the human homologs (Continued)

\begin{tabular}{|c|c|c|c|c|c|}
\hline \multicolumn{2}{|l|}{ Rat } & \multicolumn{2}{|l|}{ Human } & \multirow[t]{2}{*}{ Comments } & \multirow[t]{2}{*}{ References } \\
\hline Phenotype & $\begin{array}{l}\text { Causative } \\
\text { gene name } e^{a} \\
\text { Localisation }^{c}\end{array}$ & Phenotype & $\begin{array}{l}\text { Ortholog } \\
\text { gene name } e^{b} \\
\text { Localisation }^{c}\end{array}$ & & \\
\hline $\begin{array}{l}\text { Ataxia and seizure } \\
\text { (groggy rat) }\end{array}$ & $\begin{array}{l}\text { Cacnala }{ }^{* *} \\
19,25.45 \mathrm{Mb}\end{array}$ & FHM1, EA2, SCA6 & $\begin{array}{l}\text { CACNA1A } \\
19 \mathrm{p} 13\end{array}$ & $\begin{array}{l}\text { Positional identification of the gene which } \\
\text { shows a missense mutation in the groggy rat, } \\
\text { absent in other strains }\end{array}$ & {$[66]$} \\
\hline Ataxia- telangiectasia & $\begin{array}{l}\operatorname{Atm}^{\mathrm{ENU}, \mathrm{T}} \\
8 \mathrm{q} 24 \\
58.02 \mathrm{Mb}\end{array}$ & Ataxia- telangectiasia & $\begin{array}{l}\text { ATM } \\
11 \mathrm{q} 22.3\end{array}$ & $\begin{array}{l}\text { Rats lacking ATM (missense or KO mutation) } \\
\text { display paralysis, neuroinflammation and have } \\
\text { significant loss of motor neurons and } \\
\text { microgliosis in the spinal cord }\end{array}$ & {$[67,68]$} \\
\hline $\begin{array}{l}\text { Autism spectrum } \\
\text { disorders }\end{array}$ & $\begin{array}{l}\text { Cntnap2 }^{\top} \\
4,74.70 \mathrm{Mb}\end{array}$ & $\begin{array}{l}\text { Epilepsy (CDFE } \\
\text { syndrome) and autism } \\
\text { spectrum disorders }\end{array}$ & $\begin{array}{l}\text { CNTNAP2 } \\
7 \mathrm{q} 35-\mathrm{q} 36.1\end{array}$ & $\begin{array}{l}\text { The SD KO mutant shows a delayed } \\
\text { maturation of auditory processing pathways } \\
\text { and striking parallels to disruptions reported in } \\
\text { autism spectrum disorders; see also below: } \\
\text { Epilepsy }\end{array}$ & {$[69]$} \\
\hline $\begin{array}{l}\text { Autism spectrum } \\
\text { disorders }\end{array}$ & $\begin{array}{l}\mathrm{Fmrr} T^{\top} \\
\mathrm{Xq} 37 \\
154.68 \mathrm{Mb}\end{array}$ & $\begin{array}{l}\text { Autism spectrum } \\
\text { disorders }\end{array}$ & $\begin{array}{l}\text { FMR1 } \\
X q 27.3\end{array}$ & $\begin{array}{l}\text { The SD KO mutant exhibits abnormalities in } \\
\text { autism-relevant phenotypes including juvenile } \\
\text { play, perseverative behaviors, and } \\
\text { sensorimotor gating; see also below, Fragile X } \\
\text { syndrome model }\end{array}$ & {$[70]$} \\
\hline $\begin{array}{l}\text { Autism spectrum } \\
\text { disorders }\end{array}$ & $\begin{array}{l}\mathrm{Nlgn}^{\mathrm{T}} \\
X, 71.20 \mathrm{Mb}\end{array}$ & $\begin{array}{l}\text { Autism spectrum } \\
\text { disorders }\end{array}$ & $\begin{array}{l}\text { NLGN3 } \\
\mathrm{Xq} 13.1\end{array}$ & $\begin{array}{l}\text { The SD KO mutant exhibits abnormalities in } \\
\text { autism-relevant phenotypes including juvenile } \\
\text { play, perseverative behaviors, sensorimotor } \\
\text { gating and sleep disruptions }\end{array}$ & {$[70,71]$} \\
\hline $\begin{array}{l}\text { Autism spectrum } \\
\text { disorders }\end{array}$ & $\begin{array}{l}\text { Shank } 2^{\top} \\
1,217.15 \mathrm{Mb}\end{array}$ & $\begin{array}{l}\text { Autism spectrum } \\
\text { disorders }\end{array}$ & $\begin{array}{l}\text { SHANK2 } \\
11 q 13.3-q 13.4\end{array}$ & $\begin{array}{l}\text { The SD KO mutant exhibits social and } \\
\text { repetitive impairments, as well as a profound } \\
\text { phenotype of hyperactivity and } \\
\text { hypermotivation that can be ameliorated } \\
\text { through the administration of dopamine } \\
\text { receptor } 1 \text { or metabotropic glutamate } \\
\text { receptor } 1 \text { antagonists }\end{array}$ & [72] \\
\hline Brain development (qc) & 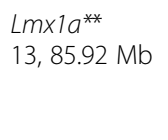 & - & - & $\begin{array}{l}\text { Positional identification of the gene, probably } \\
\text { involved in the development of the } \\
\text { ventricular system and dorsal migration of } \\
\text { neurons }\end{array}$ & [73] \\
\hline Cancer & $\begin{array}{l}\operatorname{Brca2}^{\mathrm{ENU}} \\
12 \mathrm{p} 12 \\
0.50 \mathrm{Mb}\end{array}$ & $\begin{array}{l}\text { Breast, ovarian and } \\
\text { other cancers }\end{array}$ & $\begin{array}{l}B R C A 2 \\
13 q 13.1\end{array}$ & $\begin{array}{l}\text { The SD KO mutant is sterile and develops a } \\
\text { variety of tumors; surprisingly, the female KO } \\
\text { rat does not show any increased incidence of } \\
\text { mammary carcinomas }\end{array}$ & {$[74]$} \\
\hline Cancer & $\begin{array}{l}\text { Msh6 } 6^{\mathrm{ENU}} \\
6,11.64 \mathrm{Mb}\end{array}$ & $\begin{array}{l}\text { Lynch syndrome } \\
\text { (HNPCC) }\end{array}$ & $\begin{array}{l}\text { MSH6 } \\
2 \mathrm{p} 16\end{array}$ & $\begin{array}{l}\text { Diverse tumors appear in the homozygous } \\
\text { Wistar KO mutant; the tumors exhibit } \\
\text { microsatellite instability }\end{array}$ & {$[75]$} \\
\hline Cancer & $\begin{array}{l}\text { Tp53 ENU, T } \\
10 q 24 \\
56.19 \mathrm{Mb}\end{array}$ & Li-Fraumeni syndrome & $\begin{array}{l}\text { TP53 } \\
17 p 13.1\end{array}$ & $\begin{array}{l}\text { The heterozygous KO mutants (F344, Wistar, } \\
\text { DAc8, SD) develop lymphomas or different } \\
\text { types of sarcomas (more typical of human } \\
\text { tumors than those found in Tp53 mice } \\
\text { mutants), depending on the genetic } \\
\text { background; Tp53 also controls } \\
\text { Spermatogenesis: see below, Polygenic Traits }\end{array}$ & [76-79] \\
\hline Cancer, colon & $\begin{array}{l}A p c^{\mathrm{ENU}} \\
18 \mathrm{p} 12 \\
27.01 \mathrm{Mb}\end{array}$ & Familial colon cancer & $\begin{array}{l}A P C \\
5 q 21-q 22\end{array}$ & $\begin{array}{l}\text { Two models are available; the Pirc mutant is } \\
\text { homozygous lethal while the heterozygous rat } \\
\text { develops polyposis and colon cancers, and } \\
\text { thus mimics the human } A P C \text {-dependent } \\
\text { neoplasia (unlike the ApC mutant mice); the } \\
\text { KAD mutant is homozygous, viable and shows } \\
\text { enhanced susceptibility to colon cancer- } \\
\text { inducing agents }\end{array}$ & [80-82] \\
\hline
\end{tabular}


Table 1 Alphabetical list of diseases and related traits with their causative rat genes and the human homologs (Continued)

\begin{tabular}{|c|c|c|c|c|c|}
\hline \multicolumn{2}{|l|}{ Rat } & \multicolumn{2}{|l|}{ Human } & \multirow[t]{2}{*}{ Comments } & \multirow[t]{2}{*}{ References } \\
\hline Phenotype & $\begin{array}{l}\text { Causative } \\
\text { gene name }{ }^{a} \\
\text { Localisation }^{c}\end{array}$ & Phenotype & $\begin{array}{l}\text { Ortholog } \\
\text { gene name } e^{b} \\
\text { Localisation }^{c}\end{array}$ & & \\
\hline $\begin{array}{l}\text { Cancer, multiple } \\
\text { endocrine neoplasia- } \\
\text { like syndrome X }\end{array}$ & $\begin{array}{l}C d k n 1 b^{* *} \\
4 q 43 \\
168.69 \mathrm{Mb}\end{array}$ & $\begin{array}{l}\text { Multiple endocrine } \\
\text { neoplasia type } 4\end{array}$ & $\begin{array}{l}\text { CDKN1B } \\
12 \mathrm{p} 13.1\end{array}$ & $\begin{array}{l}\text { Positional identification of the gene } \\
\text { (encoding p27 }{ }^{\text {Kip } 1} \text { ), mutated in the MNX } \\
\text { (SD }{ }^{\text {we) }} \text { rat; subsequently, a causative } \\
\text { mutation was found in the CDKN1B gene } \\
\text { of a patient presenting with pituitary and } \\
\text { parathyroid tumors; see also below, } \\
\text { Obesity and Polygenic traits, Cancer, } \\
\text { mammary gland development }\end{array}$ & {$[83,84]$} \\
\hline Cancer, renal carcinoma & $\begin{array}{l}\text { Flcn** } \\
10,46.15 \mathrm{Mb}\end{array}$ & $\begin{array}{l}\text { Birt-Hogg-Dube } \\
\text { syndrome }\end{array}$ & $\begin{array}{l}\text { BHD } \\
17 \mathrm{p} 11.2\end{array}$ & $\begin{array}{l}\text { Positional identification of the gene: frameshift } \\
\text { mutation in the Nihon rat gene, causing a } \\
\text { dominant phenotype; LOH in tumors }\end{array}$ & {$[85]$} \\
\hline $\begin{array}{l}\text { Cancer, renal carcinoma } \\
\text { (Eker rat) }\end{array}$ & $\begin{array}{l}\text { Tsc2** } \\
10 q 12 \\
13.96 \mathrm{Mb}\end{array}$ & Renal carcinoma & $\begin{array}{l}\text { TSC2 } \\
16 \mathrm{p} 3.13\end{array}$ & $\begin{array}{l}\text { Positional identification of the gene; deletion } \\
\text { of the } 3^{\prime} \text { end of the gene; LOH in tumors, } \\
\text { which only express the mutant mRNA }\end{array}$ & {$[86]$} \\
\hline $\begin{array}{l}\text { Cardiac inflammation } \\
\text { and fibrosis }\end{array}$ & $\begin{array}{l}\operatorname{Sh} 2 b 3^{\top} \\
12,40.26 \mathrm{Mb}\end{array}$ & $\begin{array}{l}\text { Increased risk of } \\
\text { myocardial infarction }\end{array}$ & $\begin{array}{l}\mathrm{SH} 2 \mathrm{~B} 3 \\
12 \mathrm{q} 24\end{array}$ & $\begin{array}{l}\text { The SS KO mutant shows exacerbated chronic } \\
\text { inflammation and fibrosis post myocardial } \\
\text { infarction; the gene also controls blood } \\
\text { pressure: see below, Polygenic Traits }\end{array}$ & [87] \\
\hline Cardiac ischemia & $\begin{array}{l}1 / 1 r / 2^{\top} \\
9,47.04 \mathrm{Mb}\end{array}$ & - & - & $\begin{array}{l}\text { An SD mutant was generated with cardiac- } \\
\text { specific } \| 1 r / 2 \text { (II36r) KO; this mutant shows } \\
\text { improved cardiac function, reduced } \\
\text { inflammatory response and apoptosis after } \\
\text { ischemia-reperfusion }\end{array}$ & {$[88]$} \\
\hline Cardiac ischemia & $\begin{array}{l}U b d^{\top} \\
20,1.87 \mathrm{Mb}\end{array}$ & - & - & $\begin{array}{l}\text { The SD KO mutant shows cardiac dysfunction } \\
\text { and increased cardiomyocyte apoptosis after } \\
\text { myocardial infarction, associated with reduced } \\
\text { Cav3 expression; the gene also controls type } 1 \\
\text { diabetes (see below) }\end{array}$ & [89] \\
\hline Cardiomyopathy & $\begin{array}{l}\text { Dnmt } T^{\top} \\
8,21.92 \mathrm{Mb}\end{array}$ & - & - & $\begin{array}{l}\text { An SD mutant was generated with cardiac- } \\
\text { specific Dnmt1 KO; this mutant shows } \\
\text { protection against pathological injury induced } \\
\text { by adryamycin (increased expression of } \\
\text { DNMT1 is observed in familial hypertrophic } \\
\text { cardiomyopathy patients) }\end{array}$ & {$[90]$} \\
\hline $\begin{array}{l}\text { Cardiomyopathy } \\
\text { (hypertrophic) }\end{array}$ & $\begin{array}{l}M_{y h 7 b^{\top}} \\
3,151.10 \mathrm{Mb}\end{array}$ & $\begin{array}{l}\text { Hypertrophic } \\
\text { cardiomyopathy }\end{array}$ & $\begin{array}{l}\text { MYH7B } \\
20 \mathrm{q} 11.22\end{array}$ & $\begin{array}{l}\text { Mutations were found in a small fraction of } \\
\text { human patients; the KO rat mutant shows } \\
\text { hypertrophic cardiomyopathy and cardiac } \\
\text { fibrosis; the CaMK-signaling pathway is } \\
\text { overexpressed in the mutant cardiomyocytes }\end{array}$ & [91] \\
\hline Cardiomyopathy(atrial) & $\begin{array}{l}M y / 4^{\top} \\
10,92.63 \mathrm{Mb}\end{array}$ & Atrial cardiomyopathy & $\begin{array}{l}\text { MYL4 } \\
17 q 21.32\end{array}$ & $\begin{array}{l}\text { The KO mutant reproduces the clinical } \\
\text { phenotype, showing atrial arrhythmia, left } \\
\text { atrial dilation and progressive atrial fibrosis }\end{array}$ & {$[40]$} \\
\hline Cardiomyopathy & $\begin{array}{l}R b m 20^{* *} \\
1,274.39 \mathrm{Mb}\end{array}$ & $\begin{array}{l}\text { Dilated } \\
\text { cardiomyopathy }\end{array}$ & $\begin{array}{l}\text { RBM20 } \\
10 \mathrm{q} 25.2\end{array}$ & $\begin{array}{l}\text { Positional identification of the gene; } \\
\text { deficiency of } R b m 20 \text { alters splicing of several } \\
\text { transcripts, such as titin and reduces exercise } \\
\text { capacity }\end{array}$ & {$[92]$} \\
\hline Cataract (NUC1 rat) & $\begin{array}{l}\text { Cryba1 } \\
10,65.16 \mathrm{Mb}\end{array}$ & Cataract & $\begin{array}{l}\text { CRYBA1 } \\
17 q 11.2\end{array}$ & $\begin{array}{l}\text { Positional identification of the gene: insertion } \\
\text { in exon } 6 \text { of the NUC1 rat; the mutation is } \\
\text { recessive and impairs the development of the } \\
\text { retinal pigmented epithelium }\end{array}$ & {$[93,94]$} \\
\hline Cataract & $\begin{array}{l}\text { Crygd }^{* *} \\
9 \mathrm{q} 32, \\
71.77 \mathrm{Mb}\end{array}$ & - & - & $\begin{array}{l}\text { Positional identification of the gene: mutation } \\
\text { in the start codon of the gene in the } \mathrm{SS} / \mathrm{Jr} \text {-Ctr } \\
\text { strain }\end{array}$ & {$[95]$} \\
\hline Cataract & $\begin{array}{l}\text { Gja3** } \\
15 \mathrm{p} 12 \\
41.15 \mathrm{Mb}\end{array}$ & Cataract & $\begin{array}{l}\text { GJA3 } \\
13 q 12.11\end{array}$ & $\begin{array}{l}\text { Positional identification of the gene: non- } \\
\text { conservative base substitution in the gene in } \\
\text { a SHRSP-derived strain }\end{array}$ & {$[96]$} \\
\hline Cataract & $\begin{array}{l}\text { Gja8** } \\
2,199.05 \mathrm{Mb}\end{array}$ & Cataract & $\begin{array}{l}\text { GJA8 } \\
1 \mathrm{q} 21\end{array}$ & $\begin{array}{l}\text { Positional identification of the gene; } 2 \text { rat } \\
\text { strains show dominant cataract due to non- }\end{array}$ & {$[97,98]$} \\
\hline
\end{tabular}


Table 1 Alphabetical list of diseases and related traits with their causative rat genes and the human homologs (Continued)

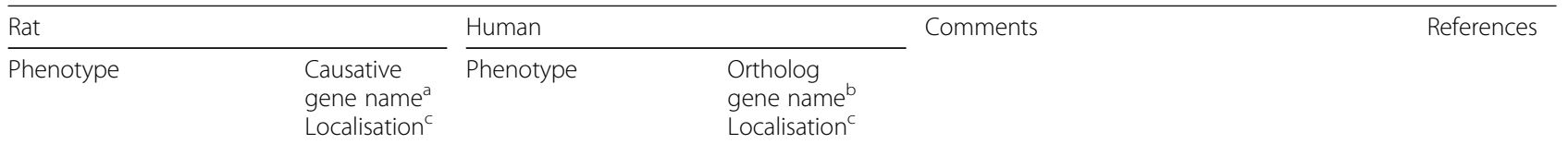

\begin{tabular}{|c|c|c|c|}
\hline Cataract & $\begin{array}{l}\text { Lss** } \\
20,12.84 \\
\mathrm{Mb}\end{array}$ & Cataract & $\begin{array}{l}\text { LSS } \\
21 \mathrm{q} 22.3\end{array}$ \\
\hline Cataract (kfrs4 mutation) & $\begin{array}{l}\text { Mip** } \\
7,2.64 \mathrm{Mb}\end{array}$ & Cataract & $\begin{array}{l}\text { MIP } \\
12 q 13.3\end{array}$ \\
\hline $\begin{array}{l}\text { Chediak-Higashi } \\
\text { syndrome model (beige) }\end{array}$ & $\begin{array}{l}\text { Lyst }^{*} \\
17,90.32 \mathrm{Mb}\end{array}$ & $\begin{array}{l}\text { Chediak-Higashi } \\
\text { syndrome } 1\end{array}$ & $\begin{array}{l}\text { LYST } \\
1 \mathrm{q} 42\end{array}$ \\
\hline $\begin{array}{l}\text { Cerebellar vermis defect } \\
(c v d) / \text { Hobble (hob) }\end{array}$ & $\begin{array}{l}U_{n c 5 c^{* *}} \\
2 q 44 \\
247.05 \mathrm{Mb}\end{array}$ & - & - \\
\hline $\begin{array}{l}\text { Coat color: albinism; } \\
\text { siamese }\end{array}$ & $\begin{array}{l}T y r^{* * *, T} \\
1 \mathrm{q} 32, \\
151.01 \mathrm{Mb}\end{array}$ & $\begin{array}{l}\text { Ocolocutaneous } \\
\text { albinism }\end{array}$ & $\begin{array}{l}\text { TYR } \\
11 q 14.3\end{array}$ \\
\hline Coat color: nonagouti & $\begin{array}{l}\text { Asip } \\
3,150.49 \mathrm{Mb}\end{array}$ & - & - \\
\hline $\begin{array}{l}\text { Coat color: head spot } \\
\text { (KFRS4/Kyo rat) }\end{array}$ & $\begin{array}{l}\text { Ednrb** } \\
15 q 22, \\
88.00 \mathrm{Mb}\end{array}$ & $\begin{array}{l}\text { Waardenburg } \\
\text { syndrome type } 4\end{array}$ & $\begin{array}{l}\text { EDNRB } \\
13 q 22\end{array}$ \\
\hline $\begin{array}{l}\text { Coat color: hooded }(h) \\
\text { and the Ws Ws rat }\end{array}$ & $\begin{array}{l}\mathrm{Kit}^{* * *} \\
14,35.07 \mathrm{Mb}\end{array}$ & - & - \\
\hline $\begin{array}{l}\text { Cockayne syndrome } \\
\text { (CS) model }\end{array}$ & $\begin{array}{l}\operatorname{Ercc}^{\top} \\
16,8.73 \mathrm{Mb}\end{array}$ & Cockayne syndrome & $\begin{array}{l}\text { ERCC6 } \\
10 q 11.23\end{array}$ \\
\hline $\begin{array}{l}\text { Congenital stationary } \\
\text { night blindness }\end{array}$ & $\begin{array}{l}\text { Cacnalf** } \\
X, 15,71 \mathrm{Mb}\end{array}$ & $\begin{array}{l}\text { Congenital stationary } \\
\text { night blindness }\end{array}$ & $\begin{array}{l}\text { CACNAIF } \\
\text { Xp11.23 }\end{array}$ \\
\hline Creeping (cre) & $\begin{array}{l}\operatorname{Re} \ln n^{*} \\
4 \mathrm{q} 11,9.35 \\
\mathrm{Mb}\end{array}$ & Lissencephaly & $\begin{array}{l}\text { RELN } \\
7 \mathrm{q} 22\end{array}$ \\
\hline Cystic fibrosis & $\begin{array}{l}\mathrm{Cftr}^{\top} \\
4 \mathrm{q} 21 \\
42.69 \mathrm{Mb}\end{array}$ & Cystic fibrosis & $\begin{array}{l}\text { CFTR } \\
7 q 31.2\end{array}$ \\
\hline
\end{tabular}

conservative base substitutions (SHR-Dca and

UPL); the SHR-Dca homozygote exhibits

microphthalmia; this mutation also lowers

blood pressure; see also below, Polygenic

Traits, Blood pressure

Positional identification of the gene:

abnormal splicing in the Shumiya cataract

rat; phenotype modified by Fdft1 (15,

$50.10 \mathrm{Mb}$ ); both genes affect cholesterol

synthesis; lanosterol treatment reduces

cataract severity

Positional identification of the gene which, in

the mutant, shows a 5 bp insertion leading to

a frameshift mutation producing a truncated

protein

Direct sequencing of the mutant rat beige

gene revealed the presence of a large deletion

Positional identification of the gene; the rat

mutation is homolog to the mouse rostral

cerebellar malformation mutation in the gene encoding netrin receptor $\mathrm{C}$

Positional identification of the siamese mutant; [104-107] an albino DA KO mutant was also generated and correction of the albino mutation was done using the CRISP-Cas system

Cloning of the basis of homology with the mouse variant: deletion in exon 2 of the nonagouti variant; correction of the mutation using the CRISP-Cas system

Positional identification of the gene; no mutation found in the gene but a deletion was identified upstream the gene in a putative enhancer

Positional identification of the gene: two different insertions found in two alleles ( $h$ and $h^{T}$ ); correction of the hooded mutation using the CRISP-Cas system; the gene is also mutated in the white spotting rat (Ws/Ws) (no melanocytes) and seems to control anemia (see above); it is also involved in Unilateral renal agenesis (see below)

The SD KO mutant displays DNA repairdeficient phenotypes and brain abnormalities, features that resemble those of CS patients

Direct sequencing of the cDNA revealed a mutation generating a stop codon in a strain of spontaneous mutant rat; in a backcross the mutation was found to segregate with the phenotype

Positional identification of the gene, mutated in the KZC rat; the rat mutant is homolog to the mouse reeler

Three mutant strains were described: two KO mutants and a mutant carrying the most frequent human mutation (F508del); they recapitulate many aspects of the human disease (defects in airway mucus production 
Table 1 Alphabetical list of diseases and related traits with their causative rat genes and the human homologs (Continued)

\begin{tabular}{|c|c|c|c|c|c|}
\hline Rat & & Human & & Comments & References \\
\hline Phenotype & $\begin{array}{l}\text { Causative } \\
\text { gene name } \\
\text { Localisation }^{c}\end{array}$ & Phenotype & $\begin{array}{l}\text { Ortholog } \\
\text { gene name } \\
\text { Localisation }^{\mathrm{c}}\end{array}$ & & \\
\hline
\end{tabular}

\begin{tabular}{|c|c|c|c|}
\hline $\begin{array}{l}\text { Cystic } \\
\text { leukoencephalopathy } \\
\text { model }\end{array}$ & $\begin{array}{l}\text { Rnaset2 }^{\top} \\
1,53.17 \mathrm{Mb}\end{array}$ & $\begin{array}{l}\text { Cystic } \\
\text { leukoencephalopathy }\end{array}$ & $\begin{array}{l}\text { RNASET2 } \\
6 \mathrm{q} 27\end{array}$ \\
\hline Cystinosis & $\begin{array}{l}\text { Ctns** } \\
10,59.75 \mathrm{Mb}\end{array}$ & Cystinosis & $\begin{array}{l}\text { CTNS } \\
17 \mathrm{p} 13.2\end{array}$ \\
\hline Danon disease model & $\begin{array}{l}\operatorname{Lamp}^{\top} \\
\mathrm{Xq} 35 \\
124.72 \mathrm{Mb}\end{array}$ & Danon disease & $\begin{array}{l}\text { LAMP2 } \\
\text { Xq24 }\end{array}$ \\
\hline $\begin{array}{l}\text { D-amino-acid oxidase } \\
\text { deficiency }\end{array}$ & $\begin{array}{l}\text { Dao** } \\
12,48.35 \mathrm{Mb}\end{array}$ & - & - \\
\hline
\end{tabular}
vas deferens, intestinal obstruction.....); see also below, Polygenic traits, Bone growth

The SD KO mutant shows no brain cystic lesions but exhibits enlarged prefrontal cortex and hippocampal complex as well as memory deficits (less severe neurodegeneration phenotype than the human patients)

\begin{tabular}{|c|c|c|}
\hline $\begin{array}{l}\text { Deafness (dfk: deafness } \\
\text { Kyoto) }\end{array}$ & $\begin{array}{l}\text { Kncq 1** } \\
1 \mathrm{q} 41 \\
223.15 \mathrm{Mb}\end{array}$ & $\begin{array}{l}\text { Long-QT syndrome, } \\
\text { deafness }\end{array}$ \\
\hline Deafness & $\begin{array}{l}\text { Myo7a** } \\
\text { 1, } 163.00 \mathrm{Mb}\end{array}$ & Usher syndrome 1B \\
\hline $\begin{array}{l}\text { Deafness; Kyoto circling } \\
(k c i)\end{array}$ & $\begin{array}{l}\text { Pcdh15** } \\
20,14.95 \mathrm{Mb}\end{array}$ & Usher syndrome $1 \mathrm{~F}$ \\
\hline $\begin{array}{l}\text { Deafness, retinal } \\
\text { dysfunction }\end{array}$ & $\begin{array}{l}\text { Myo 15a** } \\
10,46.84 \mathrm{Mb}\end{array}$ & Deafness, DFNB3 \\
\hline $\begin{array}{l}\text { Demyelination (see also } \\
\text { below: } \\
\text { Hypomyelination) }\end{array}$ & $\begin{array}{l}\text { Aspa }^{\top} \\
10,59.84 \mathrm{Mb}\end{array}$ & Canavan disease \\
\hline Demyelination (les) & $\begin{array}{l}\text { Mbp* } \\
18,79.33 \mathrm{Mb}\end{array}$ & - \\
\hline Demyelination (dmy) & $\begin{array}{l}\text { Mrs2*** } \\
17,42.64 \mathrm{Mb}\end{array}$ & - \\
\hline Demyelination (md) & $\begin{array}{l}\text { Plp 1** } \\
X, 107.50 \mathrm{Mb}\end{array}$ & - \\
\hline
\end{tabular}

KCNQ1 Positional identification of the gene, partially

Positional identification of the gene, partially mutation also causes renal glucosuria

The SD KO rat shows great similarity to human patients: hypercholesterolemia, hyperglycaemia, cardiomyopathy, and other disorders including retinopathy and chronic kidney injury

The LEA rat strain lacks DAO activity; sequencing of the gene revealed a $54.1 \mathrm{~Kb}$ deletion in the LEA strain, but not in other strains; a congenic strain carrying the mutant allele in the F344 genetic background was generated: this congenic strain shows defects in D-amino-acids metabolism deleted in the $d f k$ rat, which is also

$11 \mathrm{p} 15.5$ hypertensive

MYOTA 11q13.5 Positional identification of an ENU-induced mutation in the Wistar rat strain (tornado phenotype)

PCDH15 10q21 Positional identification of the gene, which shows a premature stop codon in the $\mathrm{kci}$ mutant

MYO15A Positional identification of the gene which 17p11.2 shows a non-conservative base substitution in the LEW/Ttm-ci2 rat, causing both deafness and blindness

ASPA The F344 KO mutant shows abnormal

17p13.2 myelination in the central nervous system (but no tremor); see also below, Tremor

Sequencing of the les Mbp gene revealed that it contains a large insertion altering the splicing of the Mbp RNA

Positional identification of the gene; complementation by cDNA transgenesis in the $d m y / d m y$ rat, which carries an inactivating novel splice acceptor site

The mutation is linked to the $X$ chromosome; sequencing of the mutant $P / p 1$ CDNA revealed a missense mutation, probably inducing a conformational change in the protein (homologous to the jimpy mouse mutant)

$\begin{array}{llll}\text { Demyelination (Taiep) } & \text { Tubb4a** } & \text { Hypomyelination } & \text { TUBB4A } \\ & 9,9.96 \mathrm{Mb} & & 19 \mathrm{p} 13.3 \\ \text { Diabetes insipidus } & \text { Avp*** } & \text { Neurohypophys-eal } & \text { AVP } \\ & 3 \mathrm{q} 35, & \text { diabetes insipidus } & \text { 20p13 } \\ & 123.12 \mathrm{Mb}\end{array}$

Positional identification of the gene which shows a missense mutation in the Taiep rat

Direct cloning of the gene which shows a single base deletion in the Brattleboro rat; complementation by transgenesis in the hypothalamus 
Table 1 Alphabetical list of diseases and related traits with their causative rat genes and the human homologs (Continued)

\begin{tabular}{|c|c|c|c|c|c|}
\hline \multicolumn{2}{|l|}{ Rat } & \multicolumn{2}{|l|}{ Human } & \multirow[t]{2}{*}{ Comments } & \multirow[t]{2}{*}{ References } \\
\hline Phenotype & $\begin{array}{l}\text { Causative } \\
\text { gene name } \\
\text { Localisation }^{\mathrm{c}}\end{array}$ & Phenotype & $\begin{array}{l}\text { Ortholog } \\
\text { gene name }{ }^{b} \\
\text { Localisation }^{c}\end{array}$ & & \\
\hline Diabetes insipidus & $\begin{array}{l}\text { Stiml }{ }^{* *} \\
1,167.37 \mathrm{Mb}\end{array}$ & Autoimmunity & $\begin{array}{l}\text { STIM1 } \\
11 \mathrm{p} 15.4\end{array}$ & $\begin{array}{l}\text { The SHR-A3 strain exhibits nephrogenic } \\
\text { diabetes insipidus; genome sequencing } \\
\text { revealed a deletion affecting the Stim1 gene is } \\
\text { in the SHR-A3 strain, but not in other strains; } \\
\text { the phenotype segregates with the mutation, } \\
\text { which compromises store-operated calcium } \\
\text { entry; this pleiotropic genes also controls } \\
\text { Behavior (stress response), Renal injury and } \\
\text { Stroke (see Polygenic traits below) }\end{array}$ & [131] \\
\hline
\end{tabular}

$\begin{array}{llll}\text { Dilute-opisthotonus } & \text { Myo5a** } & \text { Griscelli syndrome type } & \text { MYO5A } \\ \text { (dop) } & 8,82.04 \mathrm{Mb} & \mathbf{l} & 15 \mathrm{q} 21.2\end{array}$
Stroke (see Polygenic traits below)

Direct sequencing of the CDNA revealed an in frame, 47aa deletion in the dop Myo5a gene, leading to under-expression of the protein (resulting in diluted coat color and ataxia); a second mutant was identified later by whole genome sequencing: it shows several pleiotropic neuropathological and biochemical alterations leading to neurodegeneration

\begin{tabular}{|c|c|c|c|c|}
\hline $\begin{array}{l}\text { Duchenne muscular } \\
\text { dystrophy }\end{array}$ & $\begin{array}{l}\mathrm{Dmd}^{\top} \\
\mathrm{Xq} 22, \\
51.15 \mathrm{Mb}\end{array}$ & $\begin{array}{l}\text { Duchenne muscular } \\
\text { dystrophy }\end{array}$ & $\begin{array}{l}\text { DMD } \\
\text { Xp21.2-p21.1 }\end{array}$ & $\begin{array}{l}\text { Wistar or SD KO rats show several muscle } \\
\text { abnormalities (necrosis, fibrosis, reduced } \\
\text { strength, reduced motor activity) and dilated } \\
\text { cardiomyopathy }\end{array}$ \\
\hline Drug behavioral effects & $\begin{array}{l}\text { Ghsr }{ }^{\mathrm{ENU}} \\
2,113.06 \mathrm{Mb}\end{array}$ & - & - & $\begin{array}{l}\text { Cocaine-treated FHH mutant rats shows } \\
\text { diminished development of cocaine } \\
\text { locomotor sensitization relative to WT rats; see } \\
\text { also below, Food intake }\end{array}$ \\
\hline Drug metabolism & $\begin{array}{l}A b c b 1 a^{\top} \\
4 \mathrm{q} 12 \\
22.34 \mathrm{Mb}\end{array}$ & - & - & $\begin{array}{l}\text { Wistar or SD KO mutants show increased } \\
\text { brain penetration of drugs and other } \\
\text { alterations in drug pharmacokinetic } \\
\text { parameters }\end{array}$ \\
\hline Drug metabolism & $\begin{array}{l}A b c g 2^{\top} \\
4,88.76 \mathrm{Mb}\end{array}$ & - & - & $\begin{array}{l}\text { The SD KO mutant shows increased brain } \\
\text { penetration of drugs and other alterations in } \\
\text { drug pharmacokinetic parameters; see also } \\
\text { below, Hyperbilirubinemia }\end{array}$ \\
\hline Drug metabolism & $\begin{array}{l}\text { Cyp2 } 2 \mathrm{cl}^{\top} \\
1 \mathrm{q} 53 \\
257.68 \mathrm{Mb}\end{array}$ & - & - & $\begin{array}{l}\text { The SD KO mutant male shows reduced } \\
\text { fertility (CYP2C11 is a male-specific } \\
\text { cytochrome P450); expression of other P450's } \\
\text { is upregulated; in vivo, no significant } \\
\text { differences were found in drug metabolism }\end{array}$ \\
\hline Drug metabolism & $\begin{array}{l}\text { Cyp2e1 } \\
1 \mathrm{q} 41 \\
213.51 \mathrm{Mb}\end{array}$ & - & - & $\begin{array}{l}\text { The SD KO rat is physiologically normal, shows } \\
\text { a compensatory expression of CYP3A1 and } \\
\text { impaired metabolism of chlorzoxazone, a } \\
\text { CYP2E1 substrate }\end{array}$ \\
\hline Drug metabolism & $\begin{array}{l}\text { Сyp3a1 } \\
12,110.539 \\
\mathrm{Mb} \\
+{\text { Cyp } 3 a 2^{\top}}^{\top} \\
12,116,41 \\
\mathrm{Mb}\end{array}$ & - & - & $\begin{array}{l}\text { The double SD KO rat is physiologically } \\
\text { normal but shows increased testosterone } \\
\text { serum concentrations; it also shows a } \\
\text { compensatory expression of several } \\
\text { cytochrome isoforms and impaired } \\
\text { metabolism towards CYP3A1/2 substrates }\end{array}$ \\
\hline $\begin{array}{l}\text { Dwarfism (Spontaneous } \\
\text { dwarf rat) }\end{array}$ & $\begin{array}{l}G h^{* *} \\
10 \mathrm{q} 32 \\
94.48 \mathrm{Mb}\end{array}$ & Dwarfism & $\begin{array}{l}G H \\
17 q 24\end{array}$ & $\begin{array}{l}\text { Direct cloning of the gene revealed a point } \\
\text { mutation causing abnormal splicing in the } \\
\text { Spontaneous dwarf rat }\end{array}$ \\
\hline Dwarfism (mri) & $\begin{array}{l}\text { Prkg2** } \\
14,12.22 \mathrm{Mb}\end{array}$ & Growth retardation & $\begin{array}{l}\text { Candidate: PRKG2 } \\
4 \mathrm{q} 13.1-\mathrm{q} 21.1\end{array}$ & $\begin{array}{l}\text { Positional identification of the gene; } \\
\text { complementation in cultured chondrocyte by } \\
\text { cDNA transfection (restoration of } \\
\text { differentiation) }\end{array}$ \\
\hline Dwarfism (rdw rat) & $\begin{array}{l}T g^{* *} \\
7,107.47 \mathrm{Mb}\end{array}$ & - & - & $\begin{array}{l}\text { Sequencing of the } T g \text { cDNA from the } r d w \text { rat } \\
\text { revealed a missense mutation; rescue from } \\
\text { dwarfism was obtained by thyroid function }\end{array}$ \\
\hline
\end{tabular}
revealed a missense mutation; rescue from 
Table 1 Alphabetical list of diseases and related traits with their causative rat genes and the human homologs (Continued)

\begin{tabular}{|c|c|c|c|c|c|}
\hline Rat & & Human & & Comments & References \\
\hline Phenotype & $\begin{array}{l}\text { Causative } \\
\text { gene name } \\
\text { Localisation }^{c}\end{array}$ & Phenotype & $\begin{array}{l}\text { Ortholog } \\
\text { gene name } \\
\text { Localisation }^{\mathrm{c}}\end{array}$ & & \\
\hline
\end{tabular}

\begin{tabular}{|c|c|c|c|}
\hline Dwarfism (Ide/lde rat) & Wwox ${ }^{* *}$ & & \\
\hline Dystonia type 25 & $\begin{array}{l}\text { Gnal }^{\top} \\
18 \mathrm{q} 12 \\
62.80 \mathrm{Mb}\end{array}$ & Dystonia type 25 & $\begin{array}{l}\text { GNAL } \\
18 p 11\end{array}$ \\
\hline $\begin{array}{l}\text { Ear and eye } \\
\text { development (dumbo } \\
\text { mutation) }\end{array}$ & $\begin{array}{l}H m \times 1^{* *} \\
14,80.54 \mathrm{Mb}\end{array}$ & $\begin{array}{l}\text { Oculo-auricular } \\
\text { syndrome }\end{array}$ & $\begin{array}{l}H M X 1 \\
4 \mathrm{p} 16 .\end{array}$ \\
\hline Eosinophilia (MES rat) & $\begin{array}{l}\text { Cyba*** } \\
19,55.25 \mathrm{Mb}\end{array}$ & - & - \\
\hline
\end{tabular}

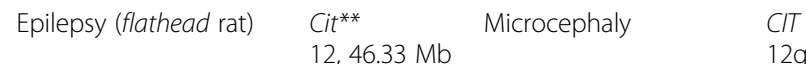

IT

$12 \mathrm{q} 23.24$

\begin{tabular}{|c|c|c|c|}
\hline Epilepsy & $\begin{array}{l}\text { Cntnap2 }^{\top} \\
4,74.70 \mathrm{Mb}\end{array}$ & $\begin{array}{l}\text { Epilepsy (CDFE } \\
\text { syndrome) and autism } \\
\text { spectrum disorders }\end{array}$ & $\begin{array}{l}\text { CNTNAP2 } \\
7 q 35-q 36.1\end{array}$ \\
\hline Epilepsy (and ataxia) & $\begin{array}{l}\mathrm{KCna1}^{\text {ENU }} \\
4 \mathrm{q} 42 \\
159.19 \mathrm{Mb}\end{array}$ & Episodic ataxia type 1 & $\begin{array}{l}\text { KCNA1 } \\
12 \mathrm{p} 13.32\end{array}$ \\
\hline $\begin{array}{l}\text { Epilepsy (ADLTE } \\
\text { mutant) }\end{array}$ & $\begin{array}{l}\text { Lgil }^{\text {ENU }} \\
1,256.95 \mathrm{Mb}\end{array}$ & Epilepsy (ADLTE) & $\begin{array}{l}L G / 1 \\
10 q 23.33\end{array}$ \\
\hline $\begin{array}{l}\text { Epilepsy (febrile seizure; } \\
\text { Hiss rat) }\end{array}$ & $\begin{array}{l}\operatorname{Sen} 1 a^{\mathrm{ENU}} \\
3,52.39 \mathrm{Mb}\end{array}$ & Febrile seizure, epilepsy & SCN1A 2q24.3 \\
\hline Epilepsy & $\begin{array}{l}\text { SV2a } \\
2,198.32 \mathrm{Mb}\end{array}$ & Epilepsy, microcephaly & $\begin{array}{l}\text { SV2A } \\
1 \mathrm{q} 21.2\end{array}$ \\
\hline Epilepsy (Ide/lde rat) & $\begin{array}{l}\text { Wwox } \\
19,46.76 \mathrm{Mb}\end{array}$ & - & - \\
\hline Fabry disease model & $\begin{array}{l}G / a^{\top} \\
X, 105.41 \mathrm{Mb}\end{array}$ & Fabry disease & $\begin{array}{l}\text { GLA } \\
\text { Xq22.1 }\end{array}$ \\
\hline Food intake & $\begin{array}{l}\text { Ghst }^{\text {ENU, T }} \\
2,113.06 \mathrm{Mb}\end{array}$ & - & - \\
\hline
\end{tabular}

compensation in $r d w$ rats

See below, Epilepsy

The SD KO mutant shows early-onset phenotypes associated with impaired dopamine transmission, such as reduction in locomotor activity and an abnormal motor skill learning ability; it may be a valuable tool for finding a suitable treatment for dystonia type 25

Positional identification of the gene; large deletion, $80 \mathrm{~kb}$ downstream the dumbo rat gene, which is not expressed in the embryo craniofacial mesenchyme

Positional identification of the gene; the mutant gene is deleted in the $5^{\prime}$ splice site of intron 4, leading to an abnormal mRNA and absence of NADPH oxidase activity; the normal phenotype was restored by transgenesis of the normal gene

Positional identification of the gene, which shows a single base deletion in the mutant rat (fh/fh), generating a stop codon; cytokinesis is defective in neuronal progenitors; this mutation also leads to microcephaly (see below)

An SD KO mutant exhibits motor seizures, hyperactivity and increased consolidation of wakefulness and rapid eye movement sleep; see also above: Autism spectrum disorders

An F344 ENU-induced mutant showing dominant myokimia, neuromyotonia and epileptic seizures was used for positional identification of the gene; expression studies in Xenopus oocytes

The F344 mutant shows early-onset spontaneous epileptic seizures and audiogenic seizure susceptibility; astrocytic Kcnj10 expression is down-regulated

The Hiss mutant shows impaired GABA receptor-mediated synaptic transmission

The F344 mutant shows a high susceptibility to the development of kindling

Positional identification of the gene, mutated (13 bp deletion) in the /de/lde rat which also shows dwarfism and abnormal testis development (these phenotypes are simultaneously inherited as a single trait)

The DA KO mutant manifests symptoms similar to those seen in Fabry patients such as altered touch and pain detection; the sensory neuron cell membrane is sensitized to mechanical probing

The FHH mutant shows reduced intake of palatable, high-calorie food (see also above, Drug behavioral effects); the Wistar KO rat shows reduced body weight and blunted 
Table 1 Alphabetical list of diseases and related traits with their causative rat genes and the human homologs (Continued)

\begin{tabular}{|c|c|c|c|c|c|}
\hline \multicolumn{2}{|l|}{ Rat } & \multicolumn{2}{|l|}{ Human } & \multirow[t]{2}{*}{ Comments } & \multirow[t]{2}{*}{ References } \\
\hline Phenotype & $\begin{array}{l}\text { Causative } \\
\text { gene name } \\
\text { Localisation }^{\mathrm{c}}\end{array}$ & Phenotype & $\begin{array}{l}\text { Ortholog } \\
\text { gene name } \\
\text { Localisation }^{\mathrm{c}}\end{array}$ & & \\
\hline & & & & food consumption & \\
\hline $\begin{array}{l}\text { Fragile } X \text { syndrome } \\
\text { model }\end{array}$ & $\begin{array}{l}\mathrm{Fmr}^{\top} \\
\mathrm{Xq} 37 \\
154.68 \mathrm{Mb}\end{array}$ & Fragile $X$ syndrome & $\begin{array}{l}\text { FMR1 } \\
\text { Xq27.3 }\end{array}$ & $\begin{array}{l}\text { Two SD KO strains are available; they show } \\
\text { disrupted cortical processing of auditory } \\
\text { stimuli, hippocampal cellular and synaptic } \\
\text { deficits, memory defects, abnormal visual } \\
\text { responses, impaired spatial learning, attention } \\
\text { deficits (deletion of the } \mathrm{KH} 1 \text { domain); see also } \\
\text { above, Autism spectrum disorders }\end{array}$ & $\begin{array}{l}([166,167] \\
\text { and } \\
\text { references } \\
\text { therein, } \\
[168])\end{array}$ \\
\hline $\begin{array}{l}\text { Fused pulmonary lobes } \\
(f p l)\end{array}$ & $\begin{array}{l}\text { Frem2** } \\
2,142.75 \mathrm{Mb}\end{array}$ & Fraser syndrome & FREM2 13q13.3 & $\begin{array}{l}\text { Direct sequencing of the } \mathrm{fp} / \mathrm{cDNA} \text { showed a } \\
\text { premature stop codon; similarity with the } \\
\text { mouse Frem } 2 \text { mutant }\end{array}$ & [169] \\
\hline $\begin{array}{l}\text { Glycogenosis (PHK } \\
\text { deficiency; gsd rat) }\end{array}$ & $\begin{array}{l}\text { Phkg2** } \\
1,199.02 \mathrm{Mb}\end{array}$ & Glycogenosis & $\begin{array}{l}\text { PHKG2 } \\
16 \mathrm{p} 11.2\end{array}$ & $\begin{array}{l}\text { Direct sequencing of the human and rat } \\
\text { cDNA's revealed mutations in patients and in } \\
\text { the gsd rat }\end{array}$ & [170] \\
\hline Hairlessness & $\begin{array}{l}H r^{* *} \\
15,52.24 \mathrm{Mb}\end{array}$ & Alopecia, atrichia & $\begin{array}{l}H R \\
8 p 21.2\end{array}$ & $\begin{array}{l}\text { ENU-induced mutant (Kyoto rhino rat) } \\
\text { selected on the basis of the phenotype and } \\
\text { then positional identification of the gene; the } \\
\text { mutant shows hair loss as well as proteinuria } \\
\text { and glomerulosclerosis }\end{array}$ & [171] \\
\hline Hairlessness & $\begin{array}{l}\text { Krt@ }{ }^{* *} \\
7 q 36, \sim 141 \\
\mathrm{Mb}\end{array}$ & - & - & $\begin{array}{l}\text { Positional identification of the locus revealing } \\
\text { a } 80 \mathrm{~kb} \text { deletion of several keratin genes in } \\
\text { the Hirosaki hairless rats }\end{array}$ & [172] \\
\hline $\begin{array}{l}\text { Hairlessness (rex } \\
\text { mutation) }\end{array}$ & $\begin{array}{l}\text { Krt71** } \\
7 \mathrm{q} 36 \\
143.35 \mathrm{Mb}\end{array}$ & - & - & $\begin{array}{l}\text { Positional identification of the gene which has } \\
\text { a } 7 \text { bp deletion at the splicing acceptor site of } \\
\text { the rex intron 1; curly hair in heterozygotes; } \\
\text { hair loss in homozygous }\end{array}$ & [173] \\
\hline Hairlessness & $\begin{array}{l}\operatorname{Prss} 8^{* *} \\
1,199.37 \mathrm{Mb}\end{array}$ & - & - & $\begin{array}{l}\text { Positional identification of the gene: } \\
\text { mutations found in affected rats (CR hairless } \\
\text { and fuzzy) }\end{array}$ & {$[174,175]$} \\
\hline $\begin{array}{l}\text { Hairlessness and } \\
\text { dermatitis }\end{array}$ & $\begin{array}{l}\text { Trpv3** } \\
10,59.83 \mathrm{Mb}\end{array}$ & - & - & $\begin{array}{l}\text { Direct sequencing of the rat CDNA, after } \\
\text { positional identification of the mouse gene: } \\
\text { dominant, missense mutation in the WBN/ } \\
\text { Kob-Ht rat and the DS-Nh mouse }\end{array}$ & {$[176]$} \\
\hline Hemochromatosis & $\begin{array}{l}\text { Tfr } 2^{*} \\
12 \mathrm{q} 12 \\
22.18 \mathrm{Mb}\end{array}$ & Hemochromatosis & $\begin{array}{l}\text { TFR2 } \\
7 q 22\end{array}$ & $\begin{array}{l}\text { Direct sequencing of the gene revealed an } \\
\text { Ala679Gly polymorphism; homozygosity for } \\
\text { this SNP is associated with the mutant } \\
\text { phenotype in a Hsd:HHCL Wistar stock }\end{array}$ & {$[177]$} \\
\hline $\begin{array}{l}\text { Hemophilia A (WAG- } \\
\text { F8m } 1 Y c b \text { ) }\end{array}$ & $\begin{array}{l}F 8^{* *, T} \\
18,367.17 \\
M b\end{array}$ & $\begin{array}{l}\text { Hemophilia A, } \\
\text { hemophilic arthropathy }\end{array}$ & $\begin{array}{l}\mathrm{F} 8 \\
\mathrm{Xq} 28\end{array}$ & $\begin{array}{l}\text { Evaluation of the individual clotting factors } \\
\text { revealed a missense mutation in the factor } \\
\text { FVIII CDNA of the mutant rat; the hemostatic } \\
\text { defect was corrected by administration of } \\
\text { human factor VIII; two KO mutants show an } \\
\text { hemophilic phenotype and seems to be good } \\
\text { models of hemophilic arthropathy or bone } \\
\text { transplantation }\end{array}$ & [178-181] \\
\hline $\begin{array}{l}\text { Heriditary tyrosinemia } \\
\text { type I model }\end{array}$ & $\begin{array}{l}\mathrm{Fah}^{\top} \\
1,146.71 \mathrm{Mb}\end{array}$ & $\begin{array}{l}\text { Heriditary tyrosinemia } \\
\text { type I }\end{array}$ & $\begin{array}{l}\text { FAH } \\
15 q 25.1\end{array}$ & $\begin{array}{l}\text { The SD KO mutant shows the major } \\
\text { manifestations of the human disease: } \\
\text { hypertyrosinemia, renal tubular damage and } \\
\text { liver fibrosis and cirrhosis; Cas9n-mediated } \\
\text { genome editing was used to correct the } \\
\text { defect }\end{array}$ & {$[182,183]$} \\
\hline $\begin{array}{l}\text { HPS model: Ruby/Red } \\
\text { eye dilution (platelet } \\
\text { storage disease) }\end{array}$ & $\begin{array}{l}\text { Rab38* } \\
1,152.07 \mathrm{Mb}\end{array}$ & HPS & - & $\begin{array}{l}\text { Direct sequencing of the gene; same } \\
\text { mutation in FH and TM rats, probably derived } \\
\text { from a common ancestor; lung surfactant } \\
\text { secretion is altered in the mutant rats; Rab38 } \\
\text { also controls proteinuria (QTL Rf2; see below) }\end{array}$ & {$[184,185]$} \\
\hline Hydrocephalus & $\begin{array}{l}\operatorname{Ccdc} 39^{\top} \\
2,120.28 \mathrm{Mb}\end{array}$ & - & - & $\begin{array}{l}\text { The SD KO mutant shows severe } \\
\text { hydrocephalus with subarachnoid }\end{array}$ & [186] \\
\hline
\end{tabular}


Table 1 Alphabetical list of diseases and related traits with their causative rat genes and the human homologs (Continued)

\begin{tabular}{|c|c|c|c|c|c|}
\hline \multicolumn{2}{|l|}{ Rat } & \multicolumn{2}{|l|}{ Human } & \multirow[t]{2}{*}{ Comments } & \multirow[t]{2}{*}{ References } \\
\hline Phenotype & $\begin{array}{l}\text { Causative } \\
\text { gene name }{ }^{a} \\
\text { Localisation }^{c}\end{array}$ & Phenotype & $\begin{array}{l}\text { Ortholog } \\
\text { gene name } \\
\text { Localisation }^{\mathrm{c}}\end{array}$ & & \\
\hline & & & & $\begin{array}{l}\text { haemorrhage and inflammatory cell invasion } \\
\text { into the perivascular space, as well as } \\
\text { impaired glymphatic cerebrospinal fluid flow }\end{array}$ & \\
\hline Hydrocephalus & $\begin{array}{l}C c d c 85 c^{\top} \\
6,132.11 \mathrm{Mb}\end{array}$ & - & - & $\begin{array}{l}\text { The F344 KO mutant shows non-obstructive } \\
\text { hydrocephalus, subcortical heterotopia and } \\
\text { intracranial hemorrhage }\end{array}$ & [187] \\
\hline Hydrocephalus, X-linked & $\begin{array}{l}\text { L1cam }^{\top} \\
\text { Xq37, } \\
156.90 \mathrm{Mb}\end{array}$ & X-linked hydrocephalus & $\begin{array}{l}\text { L1CAM } \\
\text { Xq28 }\end{array}$ & $\begin{array}{l}\text { The SD KO male mutant shows reductions in } \\
\text { fractional anisotropy and axial diffusivity in the } \\
\text { corpus callosum, external capsule, and internal } \\
\text { capsule }\end{array}$ & [188] \\
\hline
\end{tabular}

\begin{tabular}{|c|c|c|}
\hline Hyperbilirubinemia & $\begin{array}{l}A b c c 2 *{ }^{*} \mathrm{~T} \\
1,263.55 \\
\mathrm{Mb}\end{array}$ & $\begin{array}{l}\text { Hyperbilirubinemia II } \\
\text { / DJS }\end{array}$ \\
\hline
\end{tabular}

Hyperbilirubinemia

Slcolb2 ${ }^{\top}$

4, $175.81 \mathrm{Mb}$

Hyperbilirubinemia

SLCO1B3

(Rotor type)

$12 \mathrm{p} 12.2$

Hyperbilirubinemia

Ugt1a ${ }^{* * *}$

9q35,

95.30 Mb

Hypercholesterolemia

Apoe

$1,80.61 \mathrm{Mb}$

Familial APOE

deficiency

APOE

$19 q 13.32$

Hypercholesterol-emia

$L d l r^{\mathrm{ENU}, T}$

8, $22.75 \mathrm{Mb}$

Familial

hypercholesterolemia

$\angle D L R$

19p13.2

Hypercholesterol-emia Ppp4r3b**

(diet-induced: ExHc rat) $\quad 14,113.57$

$\mathrm{Mb}$

Hyperuricemia

Uox ${ }^{\top}$

2, 252.445

$\mathrm{MB}$

Hypodactyly (hd)

Cntrob**

10q24,

$55.90 \mathrm{Mb}$

Hypohidrotic ectodermal dysplasia (swh)

Hypomyelination
Edaradd**

$17,90.80 \mathrm{Mb}$

ectodermal dysplasia
Hypohidrotic gene

Direct sequencing of the CDNA in the Eisai hyperbilirubinemic rat (EHBR) revealed a premature stop codon; the same approach in the TR rat showed a 1 bp deletion; alterations were found in drug pharmacokinetics in an SD KO mutant; mutations were then discovered in the $A B C C 2$ gene of DJS patients

The SD KO mutant shows increased levels of serum bilirubin and altered pharmacokinetic behavior of pravastatin, an SLCO1B2 substrate; it could be a good model of the human Rotor syndrome

Direct sequencing of cDNA showed that the Gunn rat has a frameshift mutation in the $3^{\prime}$ region of the gene; correction of the defect could be achieved with recombinant UGTIA adenoviruses

An SD KO mutant displays

hypercholesterolemia, atherosclerosis, hepatic steatosis and decreased HDL-cholesterol levels; another mutant also shows adventitial immune infiltrates; an Apoe/Ldlr double KO mutant was also studied by Zhao et al. (2018) [195]

The F344 and SD mutants display

$[138,189-$ , atherosclerosis, xanthomatosis; hepatic steatosis was also found in the SD mutant

Positional identification of the gene, coupled with gene expression analyses; the gene is under-expressed in the ExHC rat and carries a strain-specific 10 bp deletion leading to a premature stop codon

$[193,194]$ $\begin{array}{ll}\text { No functional } & \text { The SD KO mutant is viable (unlike the mouse } \\ \text { gene } & \mathrm{KO} \text { ) and shows elevated levels of serum uric }\end{array}$ acid, providing a good model for studying hyperuricemia and associated disorders

Positional identification of the gene; the hd allele carries a retroviral insertion; centrobin thus controls both limb development and spermatogenesis

Positional identification of the gene, which shows a missense mutation in the sparse-andwavy rat (swh); sparse hair and oligodontia in this mutant rat and in human patients

The SD KO mutant shows increased axon density and relatively thinner myelin sheaths

$[195,198$, 
Table 1 Alphabetical list of diseases and related traits with their causative rat genes and the human homologs (Continued)

\begin{tabular}{|c|c|c|c|c|c|}
\hline \multicolumn{2}{|l|}{ Rat } & \multicolumn{2}{|l|}{ Human } & \multirow[t]{2}{*}{ Comments } & \multirow[t]{2}{*}{ References } \\
\hline Phenotype & $\begin{array}{l}\text { Causative } \\
\text { gene name }{ }^{a} \\
\text { Localisation }^{c}\end{array}$ & Phenotype & $\begin{array}{l}\text { Ortholog } \\
\text { gene name } e^{b} \\
\text { Localisation }^{c}\end{array}$ & & \\
\hline & & & & $\begin{array}{l}\text { around axons of the sciatic nerves; it also } \\
\text { shows increased mortality }\end{array}$ & \\
\hline Hypothyroidism & $\begin{array}{l}\text { Tshr } \\
6 \mathrm{q} 31.2 \\
115.17 \mathrm{Mb}\end{array}$ & $\begin{array}{l}\text { Congenital } \\
\text { hypothyroidism }\end{array}$ & $\begin{array}{l}\text { TSHR } \\
14 q 31.1\end{array}$ & $\begin{array}{l}\text { The SD KO mutant is infertile and shows the } \\
\text { dwarf phenotype as well as suppression of the } \\
\text { thyroid-specific genes; the phenotype can be } \\
\text { reversed by levothyroxine }\end{array}$ & [205] \\
\hline $\begin{array}{l}\text { Hypotrichosis } \\
\text { (hairlessness) }\end{array}$ & $\begin{array}{l}D s g 4^{* *} \\
18,12.06 \mathrm{Mb}\end{array}$ & $\begin{array}{l}\text { Hypotrichosis } \\
18 \mathrm{q} 12.1\end{array}$ & $\begin{array}{l}\text { DSG4 } \\
18 q 12\end{array}$ & $\begin{array}{l}\text { Direct sequencing of the IC hairless rat gene, } \\
\text { which shows a large deletion; same approach } \\
\text { in the lanceolate hair (lah) rat revealed a } \\
\text { missense mutation; positional identification of } \\
\text { the mutant gene from an SHR congenic strain, } \\
\text { which shows a premature termination codon }\end{array}$ & [206-208] \\
\hline Immunodeficiency & $\begin{array}{l}\operatorname{lgh}^{\top} \\
6 \mathrm{q} 32, \sim 150 \\
\mathrm{Mb}\end{array}$ & - & - & $\begin{array}{l}\text { Two SD KO mutants show absence of Ig and } \\
\text { B cells; transgenesis of human IG loci } \\
\text { reconstitutes B cell development and leads to } \\
\text { humanized Ig production }\end{array}$ & {$[209,210]$} \\
\hline $\begin{array}{l}\text { Immunodeficiency } \\
\text { (athymia: nude) }\end{array}$ & $\begin{array}{l}\text { Foxn1 }{ }^{* *},{ }^{\top} \\
10,65.62 \mathrm{Mb}\end{array}$ & $\begin{array}{l}\text { Lack of thymus, } \\
\text { anencephaly }\end{array}$ & $\begin{array}{l}\text { FOXN1 } \\
17 q 11.2\end{array}$ & $\begin{array}{l}\text { Following positional identification of the } \\
\text { mouse gene, the homolog rat gene was } \\
\text { found to be mutated in the nude strain, } \\
\text { disrupting thymus development and hair } \\
\text { growth; two induced Wistar mutants were } \\
\text { generated: they show thymus deficiency and } \\
\text { incomplete hairless }\end{array}$ & [211-213] \\
\hline Immuno-deficiency & $\begin{array}{l}\operatorname{Prkdc}^{\top} \\
11 \mathrm{q} 23 \\
89.29 \mathrm{Mb}\end{array}$ & $\begin{array}{l}\text { Immuno-deficiency, } \\
\text { granuloma, } \\
\text { autoimmunity }\end{array}$ & $\begin{array}{l}\text { PRDKC } \\
8 q 11.21\end{array}$ & $\begin{array}{l}\text { The F344 KO mutant shows severe combined } \\
\text { immunodeficiency and growth retardation; } \\
\text { this mutant was used to establish a model for } \\
\text { preclinical testing of human neural precursor } \\
\text { cells transplantation as a treatment of } \\
\text { neonatal brain damages; a double KO mutant } \\
\left(\text { Prkdc }{ }^{-1} \text { and } I / 2 \mathrm{rg}^{-1-}\right) \text { was also generated; this } \\
\text { double mutant shows abolishment of natural } \\
\text { killer cells }\end{array}$ & {$[214,215]$} \\
\hline $\begin{array}{l}\text { Immunodeficiency } \\
\text { (SCID) }\end{array}$ & $\begin{array}{l}\operatorname{Rag}^{\top} \\
3,91.21 \mathrm{Mb}\end{array}$ & SCID & $\begin{array}{l}\text { RAG1 } \\
11 \mathrm{p} 12\end{array}$ & $\begin{array}{l}\text { The LEW KO mutant shows lymphocyte } \\
\text { depletion (and attenuation of hypertension } \\
\text { and renal damage: see below, Polygenic traits, } \\
\text { Blood pressure) }\end{array}$ & {$[216]$} \\
\hline $\begin{array}{l}\text { Immunodifficiency } \\
\text { (SCID) }\end{array}$ & $\begin{array}{l}\operatorname{Rag}^{\top} \\
3,91.19 \mathrm{Mb}\end{array}$ & SCID & $\begin{array}{l}\text { RAG2 } \\
11 \mathrm{p} 12\end{array}$ & $\begin{array}{l}\text { The SD KO rat lacks mature B and T cells and } \\
\text { was shown to be a viable host for a range of } \\
\text { xenograft studies }\end{array}$ & {$[217]$} \\
\hline $\begin{array}{l}\text { Immunodeficiency } \\
\text { (SCID) }\end{array}$ & $\begin{array}{l}\operatorname{Rag} 1^{\top} \\
3,91.21 \mathrm{Mb} \\
\operatorname{Rag}^{\top} \\
3,91.19 \mathrm{Mb} \\
112 \mathrm{rg}^{\top} \\
\mathrm{X}, 71.17 \mathrm{Mb}\end{array}$ & - & - & $\begin{array}{l}\text { The SD triple KO mutant shows impaired } \\
\text { development of lymphoid organs, is severely } \\
\text { immunodeficient with an absence of mature } \\
T, B \text {, and NK cells and supports fast growth of } \\
\text { patient-derived xenografts thus holding great } \\
\text { potential to serve as a new model for } \\
\text { oncology research }\end{array}$ & [218] \\
\hline
\end{tabular}

$\begin{array}{llll}\text { Immunodeficiency }(X- & 112 \mathrm{rg}^{\top} & \mathrm{X} \text {-SCID } & \text { IL2RG } \\ \mathrm{SCID}) & \mathrm{X}, 71.17 \mathrm{Mb} & & \text { Xq13.1 }\end{array}$

Two KO mutants are available; they show severe combined immunodeficiency (absence of B and T lymphocytes and of NK cells); a double KO, deficient for both II2rg and Rag1, was also described: see above

$\begin{array}{llll}\text { Infertility (and } & \text { Adamts } 16^{\top}- & - \\ \text { cryptorchidism) } & 1,36.47 \mathrm{Mb} & & \\ & & & \\ & & & \\ & & & \\ \text { Infertility (testicular } & \text { Ar }^{*} & \text { Testicular feminization } & A R \\ \text { feminization) } & \text { Xq22, } & & \text { Xq12 } \\ & 67.66 \mathrm{Mb} & & \end{array}$

The KO SS homozygous mutant exhibits cryptorchidism and is infertile; the gene also controls blood pressure (see below, Polygenic traits, Blood pressure)

Direct sequencing of the gene in a testicular feminized strain: a missense mutation was found in the steroid-binding domain of the androgen receptor 
Table 1 Alphabetical list of diseases and related traits with their causative rat genes and the human homologs (Continued)

\begin{tabular}{|c|c|c|c|c|c|}
\hline \multicolumn{2}{|l|}{ Rat } & \multicolumn{2}{|l|}{ Human } & \multirow[t]{2}{*}{ Comments } & \multirow[t]{2}{*}{ References } \\
\hline Phenotype & $\begin{array}{l}\text { Causative } \\
\text { gene name } e^{a} \\
\text { Localisation }^{c}\end{array}$ & Phenotype & $\begin{array}{l}\text { Ortholog } \\
\text { gene name } \\
\text { Localisation }^{c}\end{array}$ & & \\
\hline Infertility & $\begin{array}{l}\mathrm{BsCl} 2^{\mathrm{ENU}} \\
1,225.04 \mathrm{Mb}\end{array}$ & $\begin{array}{l}\text { Congenital generalized } \\
\text { lipodystrophy }\end{array}$ & $\begin{array}{l}\text { BSCL2 } \\
11 q 12.3\end{array}$ & $\begin{array}{l}\text { The male KO mutant is infertile and shows } \\
\text { small testis and azoospermia (the female is } \\
\text { fertile); the gene could be involved in male } \\
\text { human fertility; see also below, Monogenic } \\
\text { traits, Lipodystrophy and Polygenic traits, Brain } \\
\text { development }\end{array}$ & [223] \\
\hline Infertility & $\begin{array}{l}\text { Defb } 23^{\top} \\
3,147.93 \mathrm{Mb} \\
\text { Defb } 26^{\top} \\
3,147.98 \mathrm{Mb} \\
\text { Defb42 } \\
15,46.16 \mathrm{Mb}\end{array}$ & - & - & $\begin{array}{l}\text { The male SD mutant with CRISPR/Cas9- } \\
\text { mediated single Defb gene disruption has no } \\
\text { obvious fertility phenotype but the multiple } \\
\text { KO mutant (Defb23/26 or Defb23/26/42) is } \\
\text { subfertile }\end{array}$ & [224] \\
\hline $\begin{array}{l}\text { Infertility (male } \\
\text { pseudohermaphrodism: } \\
\text { TF rat) }\end{array}$ & $\begin{array}{l}D h h^{* *} \\
7,140.58 \mathrm{Mb}\end{array}$ & Gonadal dysgenesis & $\begin{array}{l}\text { DHH } \\
12 q 13.12\end{array}$ & $\begin{array}{l}\text { Positional identification of the gene which } \\
\text { shows a missense mutation in the TF rat; the } \\
\text { mutation causes agenesis of Leydig cells and } \\
\text { androgen deficiency }\end{array}$ & [225] \\
\hline Infertility & $\begin{array}{l}\operatorname{Esr}^{\top} \\
1 \mathrm{q} 12 \\
41.19 \mathrm{Mb}\end{array}$ & - & - & $\begin{array}{l}\text { Male and female SD KO rats are infertile and } \\
\text { show gonadal pathologies; see also below, } \\
\text { Polygenic traits, Metabolism }\end{array}$ & {$[226]$} \\
\hline Infertility & $\begin{array}{l}E s r 2^{\top} \\
6 q 24.2 \\
99.16 \mathrm{Mb}\end{array}$ & - & - & $\begin{array}{l}\text { Two SD KO mutants were generated; male } \\
\text { mutants are fertile while female mutants are } \\
\text { infertile (no ovulation); however male mutants } \\
\text { exhibit prostatic glandular hyperplasia and } \\
\text { changes in expression of genes involved in } \\
\text { epithelial proliferation and benign tumor } \\
\text { formation; in the female mutants, numerous } \\
\text { granulosa cell genes are differentially } \\
\text { expressed (including Kiss1) }\end{array}$ & [227-229] \\
\hline Infertility & $\begin{array}{l}\text { Kiss } 1^{\top} \\
13,50.53 \mathrm{Mb}\end{array}$ & - & - & $\begin{array}{l}\text { The KO mutant (male and female) fails to } \\
\text { show secretion of luteinising hormone and } \\
\text { onset of puberty }\end{array}$ & [230] \\
\hline Infertility & $\begin{array}{l}\operatorname{Prdm} 14^{\top} \\
5,5.51 \mathrm{Mb}\end{array}$ & - & - & $\begin{array}{l}\text { The WI KO mutant (male and female) fails to } \\
\text { generate primordial germ cells and } \\
\text { consequently, is infertile }\end{array}$ & [231] \\
\hline Infertility (ifm mutation) & $\begin{array}{l}\text { Sbf1 } \\
7,130.26 \mathrm{Mb}\end{array}$ & $\begin{array}{l}\text { Charcot-Marie-Tooth } \\
\text { disease type 4B3 }\end{array}$ & $\begin{array}{l}\text { SBF1 } \\
22 q 13.33\end{array}$ & $\begin{array}{l}\text { Positional identification of the gene, which } \\
\text { shows a mutation at a splice site in the ifm } \\
\text { mutant; homozygous males are infertile } \\
\text { (azoospermia); females are normal }\end{array}$ & [232] \\
\hline $\begin{array}{l}\text { Infertility (tremor rat: } \\
\text { TRM/Kyo, carrying the } \\
\text { tm mutation) }\end{array}$ & $\begin{array}{l}\text { Spata22 }^{* * *} \\
10 \mathrm{q} 24 \\
59.89 \mathrm{Mb}\end{array}$ & - & - & $\begin{array}{l}\text { Positional identification of a deletion spanning } \\
\text { > } 200 \mathrm{~kb} \text {; the tm deletion causes infertility and } \\
\text { absence-like seizure in both sexes; male } \\
\text { infertility was complemented by Spata22 } \\
\text { transgenesis }\end{array}$ & [233] \\
\hline $\begin{array}{l}\text { Kininogen deficiency } \\
\text { (BN/Ka rat) }\end{array}$ & $\begin{array}{l}\text { Kng2** } \\
11,81.51 \mathrm{Mb}\end{array}$ & - & - & $\begin{array}{l}\text { Direct sequencing of the cDNA from the BN/ } \\
\text { Ka rat revealed a missense mutation which } \\
\text { impairs hepatic secretion of the protein; this } \\
\text { defect may also render vascular tissue prone } \\
\text { to aortic aneurysm formation }\end{array}$ & {$[234,235]$} \\
\hline $\begin{array}{l}\text { Lipodystrophy, } \\
\text { congenital generalized }\end{array}$ & $\begin{array}{l}\mathrm{BsCl} 2^{\mathrm{ENU}} \\
1,225.04 \mathrm{Mb}\end{array}$ & $\begin{array}{l}\text { Congenital generalized } \\
\text { lipodystrophy }\end{array}$ & $\begin{array}{l}\text { BSCL2 } \\
11 \mathrm{q} 12.3\end{array}$ & $\begin{array}{l}\text { The KO mutant develops generalized } \\
\text { lipodystrophy (lack of white adipose tissue), is } \\
\text { glucose intolerant and shows elevated plasma } \\
\text { triglyceride and concentrations; see also } \\
\text { above: Infertility and below: Polygenic Traits, } \\
\text { Brain development }\end{array}$ & [223] \\
\hline $\begin{array}{l}\text { Lipodystrophy, } \\
\text { neuropathy }\end{array}$ & $\begin{array}{l}\operatorname{Lpin} 1^{* *} \\
6,41.80 \mathrm{Mb}\end{array}$ & $\begin{array}{l}\text { Rhabdomyolysis } \\
\text { Myoglobinuria } \\
\text { Metabolic disease traits }\end{array}$ & LPIN1 2p25.1 & $\begin{array}{l}\text { ENU-induced mutant isolated on the basis of } \\
\text { the phenotype and positional identification of } \\
\text { the gene; the murine gene is mutated in the } \\
\text { fld mouse (showing adipocyte defects and } \\
\text { demyelination) }\end{array}$ & {$[236]$} \\
\hline
\end{tabular}


Table 1 Alphabetical list of diseases and related traits with their causative rat genes and the human homologs (Continued)

\begin{tabular}{|c|c|c|c|c|c|}
\hline \multicolumn{2}{|l|}{ Rat } & \multicolumn{2}{|l|}{ Human } & \multirow[t]{2}{*}{ Comments } & \multirow[t]{2}{*}{ References } \\
\hline Phenotype & $\begin{array}{l}\text { Causative } \\
\text { gene name }{ }^{a} \\
\text { Localisation }^{c}\end{array}$ & Phenotype & $\begin{array}{l}\text { Ortholog } \\
\text { gene name }{ }^{b} \\
\text { Localisation }^{c}\end{array}$ & & \\
\hline $\begin{array}{l}\text { Lymphopenia (T-cell) \& } \\
\text { IBD }\end{array}$ & $\begin{array}{l}\text { Themis** } \\
1,17.28 \mathrm{Mb}\end{array}$ & - & - & $\begin{array}{l}\text { Positional identification of the gene, which } \\
\text { shows a mutation in the } \mathrm{BN}^{\mathrm{m}} \text { rat, impairing } \\
\text { Treg function }\end{array}$ & [237] \\
\hline $\begin{array}{l}\text { Microcephaly (flathead } \\
\text { rat) }\end{array}$ & $\begin{array}{l}\mathrm{Cit}^{* *} \\
12,46.33 \mathrm{Mb}\end{array}$ & Microcephaly & $\begin{array}{l}\text { CIT } \\
12 \mathrm{q} 23.24\end{array}$ & $\begin{array}{l}\text { Positional identification of the gene, which } \\
\text { shows a single base deletion in the mutant rat } \\
\text { (fh/fh), generating a stop codon; cytokinesis is } \\
\text { defective in neuronal progenitors; this } \\
\text { mutation also leads to epilepsy (see above) }\end{array}$ & {$[153,238]$} \\
\hline Morphogenesis & $\begin{array}{l}\text { Lparr }^{\text {ENU }} \\
5,75.56 \mathrm{Mb}\end{array}$ & - & - & $\begin{array}{l}\text { The Msh6 mutant shows craniofacial disorder } \\
\text { and small size }\end{array}$ & [239] \\
\hline mTORopathy & $\begin{array}{l}\text { Depdc5 } \\
14,83.09 \mathrm{Mb}\end{array}$ & Epilepsy & $\begin{array}{l}\text { DEPDC5 } \\
22 q 12.2-q 12.3\end{array}$ & $\begin{array}{l}\text { The homozygous F344 KO rat dies in utero; } \\
\text { the heterozygous KO rat displays cortical } \\
\text { cytomegalic dysmorphic neurons and has } \\
\text { altered cortical neuron excitability } \\
\text { (upregulation of the mTORC1 pathway) }\end{array}$ & {$[240]$} \\
\hline $\begin{array}{l}\text { Mucopolysacchar-idosis } \\
\text { Vl }\end{array}$ & $\begin{array}{l}\text { Arsb*** } \\
2,23.39 \mathrm{Mb}\end{array}$ & $\begin{array}{l}\text { Mucopolysaccharidosis } \\
\text { VI }\end{array}$ & $\begin{array}{l}A R S B \\
5 q 11-q 13\end{array}$ & $\begin{array}{l}\text { Direct sequencing of the Arsb cDNA showed a } \\
\text { frame shift mutation with premature stop } \\
\text { codon in affected rats (MPR); enzyme } \\
\text { replacement therapy }\end{array}$ & {$[241,242]$} \\
\hline $\begin{array}{l}\text { Multiple mitochondrial } \\
\text { dysfunctions syndrome }\end{array}$ & $\begin{array}{l}|\mathrm{sca}|^{\top} \\
17,5.28 \mathrm{Mb}\end{array}$ & $\begin{array}{l}\text { Multiple mitochondrial } \\
\text { dysfunctions syndrome }\end{array}$ & ISCAI & $\begin{array}{l}\text { The heterozygous SD KO mutant is normal } \\
\text { but the homozygous mutant shows abnormal } \\
\text { development at } 8.5 \text { days and dies at } \\
\text { embryonic stage }\end{array}$ & {$[243]$} \\
\hline Myogenic response & $\begin{array}{l}\text { Dusp5 } 5^{\top} \\
1,274.25 \mathrm{Mb}\end{array}$ & - & - & $\begin{array}{l}\text { The } \mathrm{FHH} .1^{\mathrm{BN}} \text { congenic } \mathrm{KO} \text { mutant shows } \\
\text { greater myogenic response of cerebral arteries } \\
\text { and enhanced autoregulation of cerebral } \\
\text { blood flow }\end{array}$ & {$[244]$} \\
\hline $\begin{array}{l}\text { Neurological disorder } \\
\text { (frogleg mutation) }\end{array}$ & $\begin{array}{l}B c k d k^{* *} \\
1,199.35 \mathrm{Mb}\end{array}$ & Autism and epilepsy & $\begin{array}{l}\text { BCKDK } \\
16 \mathrm{p} 11.2\end{array}$ & $\begin{array}{l}\text { Positional identification of the gene which } \\
\text { shows a critical missense mutation in the } \\
\text { frogleg rat, causing abnormalities in hind limb } \\
\text { function, reduced brain weight, infertility, } \\
\text { seizures }\end{array}$ & {$[245]$} \\
\hline $\begin{array}{l}\text { Neuropathy } \\
\text { (Chemotherapy-induced } \\
\text { peripheral neuropathy) }\end{array}$ & $\begin{array}{l}\mathrm{C} 3^{\top} \\
9,9.72 \mathrm{Mb}\end{array}$ & - & - & $\begin{array}{l}\mathrm{C} 3 \text { is activated by neuronal cells in } \mathrm{WT} \text { rats } \\
\text { after paclitaxel administration; the } \mathrm{KO} \text { mutant } \\
\text { rat has reduced intradermal nerve fiber loss } \\
\text { and mechanical allodynia after paclitaxel } \\
\text { treatment }\end{array}$ & {$[246]$} \\
\hline $\begin{array}{l}\text { NGLY1-deficicency } \\
\text { model }\end{array}$ & $\begin{array}{l}\text { Ngly }^{\top} \\
15,10.40 \mathrm{Mb}\end{array}$ & NGLY1-deficiency & $\begin{array}{l}\text { NGLY1 } \\
3 \mathrm{p} 24.2\end{array}$ & $\begin{array}{l}\text { The SD KO mutant shows developmental } \\
\text { delay, movement disorder, somatosensory } \\
\text { impairment, axonal degradation in the sciatic } \\
\text { nerves and scoliosis, in agreement with the } \\
\text { symptoms of human patients }\end{array}$ & {$[247]$} \\
\hline Obesity & $\begin{array}{l}C d k n 1 b^{*} \\
4,168.69 \mathrm{Mb}\end{array}$ & $\begin{array}{l}\text { Multiple endocrine } \\
\text { neoplasia type } 4\end{array}$ & $\begin{array}{l}\text { CDKN1B } \\
12 \mathrm{p} 13.1\end{array}$ & $\begin{array}{l}\text { The MNX (SDwe) rat is mutated in the C } C \text { kn } 1 b \\
\text { gene and shows multiple endocrine neoplasia } \\
\text { syndrome; this mutant produces elevated } \\
\text { levels of ghrelin and shows increased food } \\
\text { intake with enhanced body fat mass; see also } \\
\text { above, Cancer, Multiple endocrine neoplasia- } \\
\text { like syndrome X and below, Polygenic traits, } \\
\text { Cancer, Mammary gland development }\end{array}$ & {$[248]$} \\
\hline Obesity & $\begin{array}{l}\text { Lep }^{\top} \\
4,56.34 \mathrm{Mb}\end{array}$ & Obesity & $\begin{array}{l}\text { LEP } \\
7 q 31\end{array}$ & $\begin{array}{l}\text { Targeted and ENU-induced mutations; F344 } \\
\text { and SD KO rats are obese, infertile and } \\
\text { immunodepressed }\end{array}$ & {$[249,250]$} \\
\hline Obesity & $\begin{array}{l}\text { Lepr }^{* *, T} \\
5,120.50 \mathrm{Mb}\end{array}$ & Obesity & $\begin{array}{l}\text { LEPR } \\
1 \mathrm{p} 31\end{array}$ & $\begin{array}{l}\text { Positional identification of the gene; missense } \\
\text { or stop mutation in the Zucker fa and } \\
\text { Koletsky obese ("corpulent") rats, respectively; } \\
\text { the SD KO mutant confirms the phenotype of } \\
\text { the spontaneous mutant, with glucose }\end{array}$ & {$[251-253]$} \\
\hline
\end{tabular}


Table 1 Alphabetical list of diseases and related traits with their causative rat genes and the human homologs (Continued)

\begin{tabular}{|c|c|c|c|c|c|}
\hline \multicolumn{2}{|l|}{ Rat } & \multicolumn{2}{|l|}{ Human } & \multirow[t]{2}{*}{ Comments } & \multirow[t]{2}{*}{ References } \\
\hline Phenotype & $\begin{array}{l}\text { Causative } \\
\text { gene name } e^{a} \\
\text { Localisation }^{c}\end{array}$ & Phenotype & $\begin{array}{l}\text { Ortholog } \\
\text { gene name } e^{b} \\
\text { Localisation }^{c}\end{array}$ & & \\
\hline & & & & $\begin{array}{l}\text { intolerance, hyperinsulinemia, dyslipidemia } \\
\text { and diabetes complications }\end{array}$ & \\
\hline Obesity & $\begin{array}{l}M c 4 r^{\mathrm{ENU}} \\
18,62.61 \mathrm{Mb}\end{array}$ & Obesity & $\begin{array}{l}M C 4 R \\
18 \mathrm{q} 22\end{array}$ & $\begin{array}{l}\text { The MSH6 KO mutant shows increased food } \\
\text { intake and adipose mass }\end{array}$ & [254] \\
\hline $\begin{array}{l}\text { Osteochondrodysplasia } \\
\text { (ocd) }\end{array}$ & $\begin{array}{l}\text { Golgb1** } \\
11,66.76 \mathrm{Mb}\end{array}$ & - & - & $\begin{array}{l}\text { Positional identification of the gene; the } \\
\text { mutant shows an abnormal skeletal system } \\
\text { and systemic edema }\end{array}$ & {$[255]$} \\
\hline $\begin{array}{l}\text { Osteopetrosis (incisors } \\
\text { absent: } i a \text { ) }\end{array}$ & $\begin{array}{l}\text { Plekhm1** } \\
10,91.45 \\
\mathrm{Mb}\end{array}$ & Osteopetrosis & $\begin{array}{l}\text { PLEKHM1 } \\
17 q 21.31\end{array}$ & $\begin{array}{l}\text { Positional identification of the gene: } \\
\text { frameshift mutation in the ia rat; } \\
\text { mutations discovered in the PLEKHM1 } \\
\text { gene of osteopetrosis patients }\end{array}$ & {$[256]$} \\
\hline $\begin{array}{l}\text { Osteoporosis } \\
\text { pseudoglioma model }\end{array}$ & $\begin{array}{l}\operatorname{Lrp5}^{\top} \\
1,218.82 \mathrm{Mb}\end{array}$ & $\begin{array}{l}\text { Osteoporosis } \\
\text { pseudoglioma }\end{array}$ & $\begin{array}{l}\angle R P 5 \\
11 \mathrm{q} 13.2\end{array}$ & $\begin{array}{l}\text { Three independent SD KO lines were } \\
\text { generated: they display decreased trabecular } \\
\text { bone mass and quality as well as sparse and } \\
\text { disorganized superficial retinal vasculature as } \\
\text { seen in LRP5-deficient humans }\end{array}$ & {$[257]$} \\
\hline $\begin{array}{l}\text { Parkinson disease } \\
\text { model }\end{array}$ & $\begin{array}{l}\operatorname{Lrrk}^{\top} \\
7,132.86 \mathrm{Mb}\end{array}$ & Familial PD (dominant) & $\begin{array}{l}\text { LRRK2 } \\
12 q 12\end{array}$ & $\begin{array}{l}\text { The Long Evans KO mutant displays weight } \\
\text { gain and an abnormal kidney, lung and liver } \\
\text { phenotype }\end{array}$ & {$[258,259]$} \\
\hline $\begin{array}{l}\text { Parkinson disease } \\
\text { model }\end{array}$ & $\begin{array}{l}\mathrm{Nr} 4 a 1^{\mathrm{ENU}} \\
7,142.90 \mathrm{Mb}\end{array}$ & - & - & $\begin{array}{l}\text { The FHH KO mutant shows reduced } \\
\text { dopamine cell loss and dyskinesia in this } \\
\text { experimental Parkinson disease model; the } \\
\text { gene also controls renal function and stress: } \\
\text { see below, Polygenic traits, Renal injury and } \\
\text { Behavior, stress response }\end{array}$ & {$[260]$} \\
\hline $\begin{array}{l}\text { Parkinson disease } \\
\text { model }\end{array}$ & $\begin{array}{l}\text { Park7 } \\
5,167.98 \mathrm{Mb}\end{array}$ & Familial PD (recessive) & PARK7 1p36.23 & $\begin{array}{l}\text { The Long Evans KO mutant shows motor } \\
\text { deficit and age-dependent neuronal loss; } \\
\text { Park7 is also involved in the control of PAH: } \\
\text { see below, Polygenic traits, Blood pressure }\end{array}$ & {$[261,262]$} \\
\hline $\begin{array}{l}\text { Parkinson disease } \\
\text { model }\end{array}$ & $\begin{array}{l}\operatorname{Prk} n^{\top} \\
1,48.88 \mathrm{Mb}\end{array}$ & Familial PD (recessive) & $\begin{array}{l}\text { PRKN } \\
6 \mathrm{q} 26\end{array}$ & $\begin{array}{l}\text { The Long Evans KO mutant is not different } \\
\text { from WT rats }\end{array}$ & {$[262]$} \\
\hline $\begin{array}{l}\text { Parkinson disease } \\
\text { model }\end{array}$ & $\begin{array}{l}\text { Pink } 1^{\top} \\
5,156.68 \mathrm{Mb}\end{array}$ & Familial PD (recessive) & $\begin{array}{l}\text { PINK1 } \\
1 \mathrm{p} 36\end{array}$ & $\begin{array}{l}\text { The Long Evans KO mutant shows motor } \\
\text { deficit and age-dependent loss of nigral } \\
\text { dopaminergic neuronal }\end{array}$ & {$[261-263]$} \\
\hline $\begin{array}{l}\text { Parkinson disease } \\
\text { model }\end{array}$ & $\begin{array}{l}\text { Snca* }^{*} \\
4,90.78 \mathrm{Mb}\end{array}$ & Familial PD (dominant) & $\begin{array}{l}\text { SNCA } \\
4 \mathrm{q} 22.1\end{array}$ & $\begin{array}{l}\text { Direct sequencing revealed a mutation in the } \\
\text { Snca mRNA } 3^{\prime} U T R \text { in a mutant rat, which } \\
\text { overexpresses synuclein alpha and shows } \\
\text { functional alterations in the dopaminergic and } \\
\text { glutamatergic systems }\end{array}$ & {$[264,265]$} \\
\hline $\begin{array}{l}\text { Phelan-McDermid } \\
\text { syndrome model }\end{array}$ & $\begin{array}{l}\text { Shank3 } \\
\text { 7, } 130.47 \mathrm{Mb}\end{array}$ & $\begin{array}{l}\text { Phelan-McDermid } \\
\text { syndrome }\end{array}$ & $\begin{array}{l}\text { SHANK3 } \\
22 q 13.33\end{array}$ & $\begin{array}{l}\text { The human neurobehavioral manifestations } \\
\text { are due to mutations in SHANK3; one of these } \\
\text { mutations (a deletion) was introduced in rats, } \\
\text { which exhibited disabilities related to those } \\
\text { seen in the human patients; these deficits } \\
\text { were attenuated by oxytocin treatment }\end{array}$ & {$[42]$} \\
\hline Pinked eyed dilution $(p)$ & $\begin{array}{l}\mathrm{Oca2}^{* *} \\
1,114.66 \mathrm{Mb}\end{array}$ & $\begin{array}{l}\text { Oculocutaneous } \\
\text { albinism }\end{array}$ & $\begin{array}{l}\text { OCA2 } \\
15 q\end{array}$ & $\begin{array}{l}\text { Direct sequencing of the Oca2 cDNA revealed } \\
\text { a deletion shared by several mutant strains, } \\
\text { that also exhibit the same haplotype, distinct } \\
\text { from control strains }\end{array}$ & {$[266]$} \\
\hline $\begin{array}{l}\text { Polycystic kidney } \\
\text { disease (ADPKD) (cy/+ } \\
\text { rat) }\end{array}$ & $\begin{array}{l}\text { Anks6 } 6^{* * *} \\
5,62.64 \mathrm{Mb}\end{array}$ & $\begin{array}{l}\text { Cystic kidney disease } \\
\text { (Nephronophthisis) }\end{array}$ & ANKS6 & $\begin{array}{l}\text { Positional identification of the gene, mutated } \\
\text { in the Han SD (cy/ }+ \text { ) rat; overexpression of the } \\
\text { mutated variant causes polycystic kidney } \\
\text { disease; mutations later found in the human } \\
\text { gene }\end{array}$ & {$[267-269]$} \\
\hline $\begin{array}{l}\text { Polycystic kidney } \\
\text { disease (ARPKD): } \\
\text { nephronophtisis }\end{array}$ & $\begin{array}{l}\text { Nek8** } \\
10,65.40 \mathrm{Mb}\end{array}$ & - & - & $\begin{array}{l}\text { Positional identification of the gene, mutated } \\
\text { in the Lewis Polycystic Kidney (LPK) rat, } \\
\text { leading to abnormally long cilia on kidney }\end{array}$ & {$[270]$} \\
\hline
\end{tabular}


Table 1 Alphabetical list of diseases and related traits with their causative rat genes and the human homologs (Continued)

\begin{tabular}{|c|c|c|c|c|c|}
\hline Rat & & Human & & Comments & References \\
\hline Phenotype & $\begin{array}{l}\text { Causative } \\
\text { gene name } \\
\text { Localisation }^{c}\end{array}$ & Phenotype & $\begin{array}{l}\text { Ortholog } \\
\text { gene name } \\
\text { Localisation }^{c}\end{array}$ & & \\
\hline
\end{tabular}

\begin{tabular}{ll}
\hline & \\
Polycystic kidney & $P 2 r \times 7^{\top}$ \\
disease (ARPKD) & $12,39.35 \mathrm{Mb}$
\end{tabular}

\section{Polycystic kidney disease (ARPKD)}

Pkhd1**

9, 26.16 Mb

ARPKD

Polycystic kidney disease (Wpk rat)

Tmem67** 5, 27.67 Mb

Meckel-Gruber syndrome (MKS3)

Polydactyly $(L x)$

Zbtb16**, ' 8, $52.99 \mathrm{Mb}$

Skeletal defects and genital hypoplasia

\begin{abstract}
Pseudoxanthoma
\end{abstract} elasticum

Reed syndrome

$\mathrm{Fh}^{\top}$

13, $93.65 \mathrm{Mb}$

Reed syndrome

Mertk*** 3, $121.24 \mathrm{Mb}$

Retinal dystrophy (Rdy) (RCS rat)

Retinal telangiectasia (BN-J rat)

$\mathrm{Crb}^{* *}$ $13,56.27 \mathrm{Mb}$ Retinal dystrophies (including telangiectasia)

Retinitis pigmentosa

Pde6b $^{\top}$

14, $2.33 \mathrm{Mb}$

Retinitis pigmentosa (autosomal recessive)

\begin{tabular}{|c|c|c|c|}
\hline Rett syndrome & $\begin{array}{l}\text { Meсp } 2^{\top} \\
X, 156.65 \mathrm{Mb}\end{array}$ & Rett syndrome & $\begin{array}{l}\text { MECP2 } \\
\text { Xq28 }\end{array}$ \\
\hline Rickets model (type 1A) & $\begin{array}{l}\text { Cyp27b1 } 1^{\top} \\
7,70.33 \mathrm{Mb}\end{array}$ & Type $1 \mathrm{~A}$ rickets & $\begin{array}{l}\text { CYP27B1 } \\
12 \mathrm{q} 14.1\end{array}$ \\
\hline Rickets model (type 2A) & $\begin{array}{l}V d r^{\top} \\
7 q 36, \\
139.34 \mathrm{Mb}\end{array}$ & Type $2 \mathrm{~A}$ rickets & $\begin{array}{l}V D R \\
12 q 13.11\end{array}$ \\
\hline
\end{tabular}

Sitosterolemia

Abcg5** $6 \mathrm{q} 12,7.94$ epithelial cells

A P2rx7 KO was generated in the polycystic kidney (PCK) rat, a model of ARPKD; the mutant shows slower cyst growth and reduction of renal pannexin-1 protein expression and daily urinary ATP excretion
ZBTB16

$11 \mathrm{q} 23.2$

PDE6B

$4 \mathrm{p} 16.3$

PKHD1

$6 \mathrm{p} 12.2$

TMEM67 8q24

ABCC6

$16 \mathrm{p} 13.11$

$\mathrm{FH}$

$1 \mathrm{q} 43$

MERTK 2q14.1

CRB1

$1 \mathrm{q} 31.3$

$12 \mathrm{q} 13.11$
Positional identification of the polycystic kidney (PCK) rat gene, which led to the identification of mutations in the homolog human gene, responsible for ARPKD

Positional identification of the rat gene, which led to the identification of mutations in the human gene responsible for MKS3; central nervous system defects are also present in humans and rats

Positional identification of the gene which shows a $2.9 \mathrm{~kb}$ deletion in the $L x$ intron 3 and is down-regulated; the heterozygous SHR KO mutant shows anomalies in the caudal part of the body (caudal regression) and growth retardation (the homozygous $\mathrm{KO}$ is lethal)

This mineralization disorder is associated with reduced plasma inorganic pyrophosphate; this study of the SD KO mutant points to a critical role of liver $A B C C 6$

The SD heterozygous KO mutant shows hematopoietic and kidney dysfunction with kidney anaplastic lesions

Positional identification of the gene: small deletion in the RCS rat, the defect of which could be corrected by gene transfer

The $\mathrm{BN}$-J rat shows several retinal abnormalities reminiscent of human macular telangiectasia; sequencing of the $\mathrm{BN}-\mathrm{J}$ and $\mathrm{BN}$ exons revealed the presence of a rearrangement in exon 6 of $\mathrm{BN}-\mathrm{J}$, which segregates with the phenotype in an F2 cross The SD KO mutant exhibits photoreceptor degeneration, profound retinal thinning and extensive degeneration of the outer nuclear layer

The SD KO mutant shows early motor and breathing abnormalities, growth retardation, malocclusion, reduction of brain weight

The Wistar KO mutant shows growth failure and rickets; administration of 25-

Hydroxyvitamin D3 results in normalization of most phenotypes, including osteogenesis

The Wistar KO mutant shows growth failure and rickets, with alopecia; a mutant containing the human mutation R270L was also isolated: it also shows rickets symptoms, reversed by 25-Hydroxyvitamin D3 administration; with the above mutant, these 2 mutants could be useful to study the effects of vitamin $D$ derivatives

Positional identification of the gene; same missense mutation in SHR, SHRSP and WKY, 
Table 1 Alphabetical list of diseases and related traits with their causative rat genes and the human homologs (Continued)

\begin{tabular}{|c|c|c|c|c|c|}
\hline \multicolumn{2}{|l|}{ Rat } & \multicolumn{2}{|l|}{ Human } & \multirow[t]{2}{*}{ Comments } & \multirow[t]{2}{*}{ References } \\
\hline Phenotype & $\begin{array}{l}\text { Causative } \\
\text { gene name } e^{a} \\
\text { Localisation }^{c}\end{array}$ & Phenotype & $\begin{array}{l}\text { Ortholog } \\
\text { gene name }{ }^{\mathrm{b}} \\
\text { Localisation }^{c}\end{array}$ & & \\
\hline & $\mathrm{Mb}$ & & $2 \mathrm{p} 21$ & exhibiting elevated plant sterol accumulation & \\
\hline $\begin{array}{l}\text { Small eye ( } r \text { Sey): } \\
\text { microphthalmia }\end{array}$ & $\begin{array}{l}\text { Pax6* } \\
3,95.70 \mathrm{Mb}\end{array}$ & $\begin{array}{l}\text { Aniridia, mental } \\
\text { retardation, autism }\end{array}$ & $\begin{array}{l}\text { PAX6 } \\
11 \mathrm{p} 13\end{array}$ & $\begin{array}{l}\text { Direct sequencing of the mutant CDNA, which } \\
\text { shows a } 0.6 \mathrm{~kb} \text { deletion; impaired migration of } \\
\text { neural crest cells; the mutant rat may have } \\
\text { some phenotypic component of autism }\end{array}$ & {$[288,289]$} \\
\hline $\begin{array}{l}\text { Spondylocostal } \\
\text { dysostosis (Oune } \\
\text { mutation) }\end{array}$ & $\begin{array}{l}\text { Tbx6** } \\
\text { 1, } 198.21 \mathrm{Mb}\end{array}$ & $\begin{array}{l}\text { Spondylocostal } \\
\text { dysostosis }\end{array}$ & $\begin{array}{l}\text { TBX6 } \\
16 \mathrm{p} 11.2\end{array}$ & $\begin{array}{l}\text { ENU-induced semi-dominant mutation, } \\
\text { causing a short and kinked tail and several } \\
\text { skeletal abnormalities; positional identification } \\
\text { of the mutant gene }\end{array}$ & [290] \\
\hline Tenogenesis & $\begin{array}{l}M k x^{\top} \\
17,60.54 \mathrm{Mb}\end{array}$ & - & - & $\begin{array}{l}\text { The Wistar KO mutant shows heterotopic } \\
\text { ossification of the Achilles tendon via failed } \\
\text { tenogenesis }\end{array}$ & [291] \\
\hline $\begin{array}{l}\text { Teratoma and infertility } \\
\text { (ter) in both sexes }\end{array}$ & $\begin{array}{l}\text { Dnd } 1^{* *} \\
18,29.61 \mathrm{Mb}\end{array}$ & - & - & $\begin{array}{l}\text { Positional identification of the gene: } \\
\text { premature stop codon in WKY/Ztm rats; } \\
\text { homologous to the mouse mutation Ter } \\
\text { (which induces testicular teratomas only) }\end{array}$ & [292] \\
\hline $\begin{array}{l}\text { Testicular feminization } \\
\text { (Tfm) }\end{array}$ & $\begin{array}{l}A r^{*} \\
X q 22, \\
67.66 \mathrm{Mb}\end{array}$ & Testicular feminization & $\begin{array}{l}A R \\
X q 12\end{array}$ & $\begin{array}{l}\text { Direct sequencing of cDNA: single base } \\
\text { alteration in the Ar gene leads to androgen } \\
\text { insensitivity and lack of male sexual } \\
\text { development }\end{array}$ & {$[222]$} \\
\hline $\begin{array}{l}\text { T-helper immuno- } \\
\text { deficiency (thid) }\end{array}$ & $\begin{array}{l}\text { Ptprk** } \\
1,17.44 \mathrm{Mb}\end{array}$ & - & - & $\begin{array}{l}\text { Positional identification of the gene: large } \\
\text { deletion in LEC rats, the phenotype of which } \\
\text { could be rescued by reconstitution with } \\
\text { normal bone marrow cells }\end{array}$ & {$[293,294]$} \\
\hline $\begin{array}{l}\text { Toothless (t), } \\
\text { osteopetrosis }\end{array}$ & $\begin{array}{l}\text { Csf1** } \\
2,210.52 \mathrm{Mb}\end{array}$ & - & - & $\begin{array}{l}\text { Positional identification of the gene: early stop } \\
\text { codon in the } t \text { Csf1 gene; similar to the } \\
\text { mouse op; see below, Polygenic traits, } \\
\text { Macrophage development for Csf1r KO rats }\end{array}$ & {$[295,296]$} \\
\hline $\begin{array}{l}\text { Toxicity: aflatoxin B1 } \\
\text { toxicity }\end{array}$ & $\begin{array}{l}\mathrm{Nfe} 212^{\top} \\
3,62.50 \mathrm{Mb}\end{array}$ & - & - & $\begin{array}{l}\text { The F344 KO mutant is highly sensitive to } \\
\text { aflatoxin B1 toxicity, due to impaired capacity } \\
\text { for detoxification; Nfe2/2 also controls } \\
\text { vasculature function: see below }\end{array}$ & [297] \\
\hline $\begin{array}{l}\text { Toxicity: anthrax toxin } \\
\text { susceptibility }\end{array}$ & $\begin{array}{l}\mathrm{N} / \mathrm{rp} 1^{* *} \\
10 \mathrm{q} 24 \\
57.69 \mathrm{Mb}\end{array}$ & - & - & $\begin{array}{l}\text { Susceptibility maps in the region of N/rp1 (in } \\
\text { recombinant inbred strains) and gene } \\
\text { polymorphism is correlated with susceptibility } \\
\text { in several rat strains; the gene also controls } \\
\text { Toxoplasma susceptibility: see below }\end{array}$ & [298] \\
\hline $\begin{array}{l}\text { Toxoplasma } \\
\text { susceptibility (Toxo 1) }\end{array}$ & $\begin{array}{l}\mathrm{N} / \mathrm{rp} 1^{* * *} \\
10 \mathrm{q} 24 \\
57.69 \mathrm{Mb}\end{array}$ & $\begin{array}{l}\text { Toxoplasmosis } \\
\text { susceptibility }\end{array}$ & $\begin{array}{l}\text { NLRP1 } \\
17 \mathrm{p} 13.2\end{array}$ & $\begin{array}{l}\text { Positional identification of the gene; KO of } \\
\text { NIrp1 in macrophages modifies Toxoplasma } \\
\text { replication; in humans, association between } \\
\text { NLRP1 polymorphism and toxoplasmosis } \\
\text { susceptibility; the gene also controls sensitivity } \\
\text { to anthrax toxin: see above }\end{array}$ & [299] \\
\hline $\begin{array}{l}\text { Tremor (tremor rat: } \\
\text { TRM/Kyo, carrying the } \\
\text { tm mutation) }\end{array}$ & $\begin{array}{l}\text { Aspa } a^{* \top} \\
10,59.84 \mathrm{Mb}\end{array}$ & Canavan disease & $\begin{array}{l}\text { ASPA } \\
17 \mathrm{p} 13.2\end{array}$ & $\begin{array}{l}\text { Positional identification of a deletion spanning } \\
\text { > } 200 \mathrm{~kb} \text { in the TRM/Kyo rat; injection of N- } \\
\text { acetyl-L-aspartate, the Aspa precursor, induces } \\
\text { absence-like seizure in normal rats (the tremor } \\
\text { rat exhibits absence-like seizure); an F344 KO } \\
\text { mutant shows abnormal myelination but no } \\
\text { tremor; however an Aspa/Hcn1 double mutant } \\
\text { shows tremor, like the TRM/Kyo rat, which is a } \\
\text { double mutant (see below, Polygenic traits, } \\
\text { Epilepsy, tremor, Hcn 1); the pathogenesis of } \\
\text { tremor involves ionotropic glutamate } \\
\text { receptors }\end{array}$ & $\begin{array}{l}{[124,300} \\
301]\end{array}$ \\
\hline $\begin{array}{l}\text { Tremor: Zitter rat (zi } \\
\text { mutation) }\end{array}$ & $\begin{array}{l}\text { Atrn*** } \\
3 \mathrm{q} 35 \\
123.43 \mathrm{Mb}\end{array}$ & - & - & $\begin{array}{l}z i \text { induces hypomyelination and vacuolation in } \\
\text { the CNS; positional identification of the gene; } \\
z i \text { is homologous to the mouse } m g\end{array}$ & {$[302,303]$} \\
\hline
\end{tabular}


Table 1 Alphabetical list of diseases and related traits with their causative rat genes and the human homologs (Continued)

\begin{tabular}{|c|c|c|c|}
\hline \multicolumn{2}{|l|}{ Rat } & \multicolumn{2}{|l|}{ Human } \\
\hline Phenotype & $\begin{array}{l}\text { Causative } \\
\text { gene name } e^{a} \\
\text { Localisation }^{c}\end{array}$ & Phenotype & $\begin{array}{l}\text { Ortholo } \\
\text { gene na } \\
\text { Localisa }\end{array}$ \\
\hline $\begin{array}{l}\text { Tremor: VF rat (vf } \\
\text { mutation) }\end{array}$ & $\begin{array}{l}\text { Dopey } 7^{* *} \\
8,94.12 \mathrm{Mb}\end{array}$ & - & - \\
\hline Tremor (Trdk mutation) & $\begin{array}{l}\text { Kcnn2** } \\
18,39.33 \mathrm{Mb}\end{array}$ & - & - \\
\hline $\begin{array}{l}\text { Unilateral renal agenesis } \\
\text { (URA; Renag1) }\end{array}$ & $\begin{array}{l}\mathrm{Kit}^{* * *} \\
14,37.07 \mathrm{Mb}\end{array}$ & - & - \\
\hline Warfarin resistance $(r w)$ & $\begin{array}{l}\text { Vkorcl**1, } \\
\text { 199.34 Mb }\end{array}$ & $\begin{array}{l}\text { VKCFD2 and warfarin } \\
\text { resistance }\end{array}$ & $\begin{array}{l}\text { VKORC1 } \\
16 \mathrm{p} 11.2\end{array}$ \\
\hline Wilson disease model & $\begin{array}{l}\text { Atp7b** } \\
16 \mathrm{q} 12 \\
74.87 \mathrm{Mb}\end{array}$ & Wilson disease & $\begin{array}{l}\text { ATP7B } \\
13 q 14.3\end{array}$ \\
\hline Wolfram disease model & $\begin{array}{l}\text { Wfs } 1{ }^{\top} \\
14,78.64 \mathrm{Mb}\end{array}$ & Wolfram disease & $\begin{array}{l}\text { WFS1 } \\
4 \mathrm{p} 16.1\end{array}$ \\
\hline
\end{tabular}

Wolman disease model Lipa*

(Wolman rat)

$1,252.82 \mathrm{Mb}$

Wolman disease

LIPA

$10 \mathrm{q} 23$

B) Polygenic traits (QTL symbol)
Addiction: alcohol consumption
Adcyap $1 \mathrm{r} 1^{*}$

4, $85.66 \mathrm{Mb}$
Alcohol consumption in women
ADCYAP1R1

7p14.3

(Association study)
References

(mahogany); complementation by transgenic membrane-type Atrn

vf induces hypomyelination and vacuolation in the CNS; positional identification of the gene, which carries a nonsense mutation

ENU-induced missense mutation; positional identification of the mutant gene

$\mathrm{ACl}$ rats exhibit URA and white spotting; positional identification of the gene, which carries an insertion; removing the insertion by the CRISPR/Cas9 system corrects the disease and the white spotting phenotype; Kit also controls the hooded phenotype: see above, Coat color; the gene may also control anemia (see above)

Positional identification of the gene, mutated in warfarin resistance (humans and rats) and VKCFD2 (humans)

Positional identification of the gene: deletion in the LEC rat gene, causing hepatitis

The SD KO mutant shows the core symptoms of the human disease: diabetes mellitus, glycosuria, neurodegeneration; treatment with a GLP1 receptor agonist prevents the development of diabetic phenotype in the KO rat

Direct sequencing of the mutant rat CDNA: deletion of the Lipa gene in the Wolman rat

Positional identification of the gene and expression studies in congenic strains; the trait is female-specific; Adcyap $1 r 1$ is upregulated in alcohol-preferring females and its promoter contains several ERE's and polymorphisms associated with a differential response to estrogen stimulation in vitro

Positional identification of the gene; stop codon in the alcohol-preferring rat strain allele; (see also above, Monogenic traits, Addiction; opioid consumption); however, this conclusion was challenged on the basis of experiments showing that a lentiviraldelivered short-hairpin RNA-mediated KO of Grm2 does not promote alcohol drinking

Polymorphisms in the promoter, coding region, and

3'UTR were associated with altered CRHR2 binding density in alcohol-preferring rat strain (no mapping of the trait)

DNA sequencing of rats from HS-derived high- and low-alcohol-drinking lines revealed several genomic regions showing signature of selection, including genes located in previously identified QTLS ${ }^{\circ}$

See comment above, on Cyp4f18

$[306,307]$

$[308,309]$

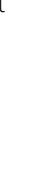

[316-318]
Addiction: alcohol
Cyp4f18**
consumption (A/c11/13) 16, $19.50 \mathrm{Mb}$
Addiction: alcohol Fam129 $C^{* *} \quad-$ consumption (A/c11/13) 16, 20.03 Mb


Table 1 Alphabetical list of diseases and related traits with their causative rat genes and the human homologs (Continued)

\begin{tabular}{|c|c|c|c|c|c|}
\hline \multicolumn{2}{|l|}{ Rat } & \multicolumn{2}{|l|}{ Human } & \multirow[t]{2}{*}{ Comments } & \multirow[t]{2}{*}{ References } \\
\hline Phenotype & $\begin{array}{l}\text { Causative } \\
\text { gene name }{ }^{a} \\
\text { Localisation }^{c}\end{array}$ & Phenotype & $\begin{array}{l}\text { Ortholog } \\
\text { gene name }{ }^{b} \\
\text { Localisation }^{c}\end{array}$ & & \\
\hline $\begin{array}{l}\text { Addiction: alcohol } \\
\text { consumption (Alc5/9/ } \\
\text { 12) }\end{array}$ & $\begin{array}{l}\text { Grin2a** } \\
10 q 11 \\
5.71 \mathrm{Mb}\end{array}$ & - & - & See comment above, on Cyp4f18 & {$[320]$} \\
\hline $\begin{array}{l}\text { Addiction: alcohol } \\
\text { consumption (Alc11/13) }\end{array}$ & $\begin{array}{l}\text { Myo9b** } \\
16,19.67 \mathrm{Mb}\end{array}$ & - & - & See comment above, on Cyp4f18 & {$[320]$} \\
\hline $\begin{array}{l}\text { Addiction: alcohol } \\
\text { consumption }\end{array}$ & $\begin{array}{l}\mathrm{Npy}^{\top} \\
4,79.56 \mathrm{Mb}\end{array}$ & - & - & $\begin{array}{l}\text { Npy deletion in an alcohol non-preferring rat } \\
\text { model elicits differential effects on alcohol } \\
\text { consumption and body weight }\end{array}$ & [321] \\
\hline $\begin{array}{l}\text { Addiction: alcohol } \\
\text { consumption (Alc11/13) }\end{array}$ & $\begin{array}{l}\text { Pgls** } \\
16,20.02 \mathrm{Mb}\end{array}$ & - & - & See comment above, on Cyp4f18 & [320] \\
\hline Adiposity & $\begin{array}{l}\text { Angpt } 18^{\top} \\
8,22.86 \mathrm{Mb}\end{array}$ & - & - & $\begin{array}{l}\text { The F344 KO mutant shows lower body } \\
\text { weight, lower fat content and lower } \\
\text { triglyceride levels, but higher heart lipase } \\
\text { levels than WT rats }\end{array}$ & [322] \\
\hline Allergic rhinitis & $\begin{array}{l}\text { Mucl }^{\top} \\
2,188.54 \mathrm{Mb}\end{array}$ & - & - & $\begin{array}{l}\text { The SD KO rat shows aggravation of allergic } \\
\text { rhinitis and suppression of expression of } \\
\text { epithelial cell connection proteins }\end{array}$ & [323] \\
\hline Angiogenesis & $\begin{array}{l}\text { Agtrla } \\
17 \mathrm{q} 12 \\
35.90 \mathrm{Mb}\end{array}$ & - & - & $\begin{array}{l}\text { The SS KO rat shows no response to injection } \\
\text { of angiotensin II (as expected) and no increase } \\
\text { in hind limb vessel density upon angiotensin- } \\
\text { (1-7) infusion (the effects of which are } \\
\text { mediated by Mas 1), indicating an AGTR1A- } \\
\text { MAS1 interaction; the gene also controls } \\
\text { Blood pressure (see below) }\end{array}$ & [324] \\
\hline Angiogenesis & $\begin{array}{l}\text { Wars2**T } \\
2 \mathrm{q} 34 \\
201.17 \mathrm{Mb}\end{array}$ & $\begin{array}{l}\text { Cardio-metabolic } \\
\text { phenotypes }\end{array}$ & $\begin{array}{l}\text { WARS2 } \\
1 \mathrm{p} 12\end{array}$ & $\begin{array}{l}\text { Positional identification of the gene } \\
\text { controlling coronary flow; the BN KO mutant } \\
\text { shows diminished cardiac capillary density } \\
\text { and reduced coronary flow; the gene also } \\
\text { controls the metabolic syndrome: see below }\end{array}$ & {$[325]$} \\
\hline $\begin{array}{l}\text { Aorta elastic tissue } \\
\text { integrity (Vetf3) }\end{array}$ & $\begin{array}{l}\text { Pi15** } \\
5,0.79 \mathrm{Mb}\end{array}$ & - & - & $\begin{array}{l}\text { High resolution mapping in a } \mathrm{HS} \text {; lower } \\
\text { expression of Pi15 in the susceptible strain BN } \\
\text { (combined with higher expression of a long } \\
\text { intergenic noncoding RNA) }\end{array}$ & {$[326]$} \\
\hline Arthritis & $\begin{array}{l}\text { Cllta** } \\
10,5.21 \mathrm{Mb}\end{array}$ & $\begin{array}{l}\text { RA, MS, myocardial } \\
\text { infarction }\end{array}$ & $\begin{array}{l}\text { CIITA } \\
16 p 13\end{array}$ & $\begin{array}{l}\text { Positional identification of the rat gene, } \\
\text { definitively identified by sequencing and } \\
\text { expression analysis; in humans, } \\
\text { polymorphism in the promoter was } \\
\text { associated with disease susceptibility }\end{array}$ & [327] \\
\hline $\begin{array}{l}\text { Arthritis } \\
\text { (Pia7, Oia2) }\end{array}$ & $\begin{array}{l}\text { Clec4b** } \\
4 q 42 \\
156.11 \mathrm{Mb}\end{array}$ & RA & $\begin{array}{l}\text { CLEC4A } \\
12 \mathrm{p} 13\end{array}$ & $\begin{array}{l}\text { Positional identification of the Aplec rat } \\
\text { gene complex and then of the Clec } 4 b \\
\text { gene; association was found between RA } \\
\text { and } C L E C 4 A(=D C I R) \text { in human patients }\end{array}$ & [328-331] \\
\hline Arthriris & $\begin{array}{l}\text { Fcgrla }^{\top} \\
2,198.43 \mathrm{Mb}\end{array}$ & - & - & $\begin{array}{l}\text { A conditional SD KO rat was generated in } \\
\text { which the gene was inactivated in the dorsal } \\
\text { root ganglion; the rat shows attenuation of } \\
\text { pain upon antigen-induced arthritis, indicating } \\
\text { that neuronal FCGR1A contributes to arthritic } \\
\text { pain }\end{array}$ & [332] \\
\hline Arthritis & $\begin{array}{l}\mathrm{Git}^{\top} \\
12,47.59 \mathrm{Mb}\end{array}$ & - & - & $\begin{array}{l}\text { The SD KO rat with induced arthritis shows a } \\
\text { more severe disease, with decreased collagen } \\
\text { II expression and increased expression of } \\
\text { inflammatory cytokines }\end{array}$ & [333] \\
\hline Arthritis: gout & $\begin{array}{l}\text { P2ry } 14^{\top} \\
2,149.33 \mathrm{Mb}\end{array}$ & - & - & $\begin{array}{l}\text { The SD KO rat shows disruption of urate- } \\
\text { induced histopathologic changes in rat } \\
\text { synoviums, accompanied with a significant } \\
\text { inhibition of pyroptotic macrophage death }\end{array}$ & [334] \\
\hline Arthritis: PIA & Hip $1^{* *}$ & - & - & Positional identification of the gene, which is & [335] \\
\hline
\end{tabular}


Table 1 Alphabetical list of diseases and related traits with their causative rat genes and the human homologs (Continued)

\begin{tabular}{|c|c|c|c|c|c|}
\hline \multicolumn{2}{|l|}{ Rat } & \multicolumn{2}{|l|}{ Human } & \multirow[t]{2}{*}{ Comments } & \multirow[t]{2}{*}{ References } \\
\hline Phenotype & $\begin{array}{l}\text { Causative } \\
\text { gene name }{ }^{a} \\
\text { Localisation }^{c}\end{array}$ & Phenotype & $\begin{array}{l}\text { Ortholog } \\
\text { gene name }{ }^{\mathrm{b}} \\
\text { Localisation }^{c} \\
\end{array}$ & & \\
\hline & $\begin{array}{l}12 \mathrm{q} 16 \\
24.18 \mathrm{Mb}\end{array}$ & & & $\begin{array}{l}\text { required for the increased invasiveness of } \\
\text { synoviocytes from arthritic rats and from RA } \\
\text { patients }\end{array}$ & \\
\hline Arthritis (Pia8) & $1122 \mathrm{ra}^{* *}$ & & & See Eae29 & \\
\hline Arthritis (Pia4) & $\begin{array}{l}\text { Ncf1 } 1^{* *} \\
12,25.50 \\
M b\end{array}$ & RA & $\begin{array}{l}\text { NCF4 } \\
22 q 13.1\end{array}$ & $\begin{array}{l}\text { Positional identification of the gene and of } \\
\text { the causative mutation; the gene controls } \\
\text { the production of reactive oxygen species; } \\
\text { see also below: Experimental autoimmune } \\
\text { neuritis }\end{array}$ & $\begin{array}{l}{[43,330} \\
336,337]\end{array}$ \\
\hline Arthritis: PIA & $\begin{array}{l}\text { Lta, Ltb, Tnf, } \\
\text { Lst1, Ncr3** } \\
\text { 20p12, } \\
\text { 3.65-3.71 Mb }\end{array}$ & - & - & $\begin{array}{l}\text { Positional identification of a recombination- } \\
\text { resistant } 33 \mathrm{~kb} \text { segment, made of } 5 \text { genes, } \\
\text { within the MHCIII region; one conserved } \\
\text { haplotype regulates arthritis; haplotype- } \\
\text { specific differences in gene expression and } \\
\text { alternative splicing correlate with susceptibility } \\
\text { to arthritis; the haplotype specifically regulates } \\
\text { adjuvant-induced arthritis, but not antigen- } \\
\text { induced autoimmunity }\end{array}$ & {$[338,339]$} \\
\hline Arthritis: Pial & $\begin{array}{l}R T 1-B a^{* *} \\
20 \mathrm{p} 12 \\
4.07 \mathrm{Mb} \text { and } \\
\text { RT1-Bb** } \\
20 \mathrm{p} 12 \\
4.04 \mathrm{Mb}\end{array}$ & RA & $\begin{array}{l}\text { MHCII } \\
6 p 21.32\end{array}$ & $\begin{array}{l}\text { Using a mixed genetic and functional } \\
\text { approach, these } 2 \text { genes (orthologs of the } \\
\text { human HLA-DQA and HLA-DQB loci, in the } \\
\text { MHCIl region) were shown to control the } \\
\text { onset and severity of PIA }\end{array}$ & [340] \\
\hline Arthritis: PIA & $\begin{array}{l}\operatorname{Vav1} 1^{* *} \\
9 q 12,9.62 \\
\mathrm{Mb}\end{array}$ & RA & $\begin{array}{l}\text { VAV1 } \\
19 \mathrm{p} 13.2\end{array}$ & $\begin{array}{l}\text { Polymorphism in Vav1 controls PIA in the } \\
\text { rat; in humans, VAV1 SNPs are associated } \\
\text { with RA; see also below, Eae4 }\end{array}$ & [341] \\
\hline Asthma & $\begin{array}{l}\operatorname{Trpa1}^{\top} \\
5,3.78 \mathrm{Mb}\end{array}$ & - & - & $\begin{array}{l}\text { The SD KO rat is largely protected from } \\
\text { immune cell infltration into bronchoalveolar } \\
\text { lung fuid in the ovalbumin model of asthma; } \\
\text { on the other hand, it shows normal behavioral } \\
\text { responses in multiple models of pain and itch }\end{array}$ & [342] \\
\hline Behavior & $\begin{array}{l}\mathrm{Cp} / x 1^{\top} \\
14,2.20 \mathrm{Mb}\end{array}$ & - & - & $\begin{array}{l}\text { The SD KO mutant shows severe ataxias and } \\
\text { tremor, dystonia, uncoordinated locomotion, } \\
\text { exploratory deficits, anxious behavior and } \\
\text { sensory deficits as well as decreased dendritic } \\
\text { branching in spinal motor neurons }\end{array}$ & [343] \\
\hline Behavior & $\begin{array}{l}P h f 24^{\top} \\
5,58.36 \mathrm{Mb}\end{array}$ & - & - & $\begin{array}{l}\text { The F344 KO mutant shows no apparent } \\
\text { changes in gross behaviors during } \\
\text { adolescence but, at older age, it exhibits } \\
\text { elevated spontaneous locomotor activity, } \\
\text { emotional hyper-reactivity, reduced anxiety } \\
\text { behaviors and cognitive deficits; it also shows } \\
\text { a higher sensitivity to induced convulsive } \\
\text { seizures }\end{array}$ & [344] \\
\hline $\begin{array}{l}\text { Behavior: Attention- } \\
\text { deficit hyperactivity } \\
\text { disorde rmodel }\end{array}$ & $\begin{array}{l}\text { Adgr }^{\top} 3^{\top} \\
14,28.36 \mathrm{Mb}\end{array}$ & $\begin{array}{l}\text { Attention-deficit } \\
\text { hyperactivity disorder }\end{array}$ & $\begin{array}{l}\text { ADGRL3 } \\
4 \mathrm{q} 13.1\end{array}$ & $\begin{array}{l}\text { The SD KO mutant shows persistent } \\
\text { hyperactivity, increased acoustic startle, } \\
\text { reduced activity in response to amphetamine } \\
\text { and female-specific reduced anxiety-like } \\
\text { behavior; dopamine signaling is dysregulated } \\
\text { in the neostriatum }\end{array}$ & {$[345,346]$} \\
\hline $\begin{array}{l}\text { Behavior: aggressive } \\
\text { phenotype }\end{array}$ & $\begin{array}{l}\operatorname{Tph} 2^{\top} \\
7,58.04 \mathrm{Mb}\end{array}$ & - & - & $\begin{array}{l}\text { The DA KO mutant exhibits (as expected) } \\
\text { profoundly diminished serotonin level and } \\
\text { displays increased aggressiveness }\end{array}$ & [347] \\
\hline Behavior: anxiety & $\begin{array}{l}\text { Cckar }^{*} \\
14,59.61 \mathrm{Mb}\end{array}$ & - & - & $\begin{array}{l}\text { Gene deletion in the OLETF rat; no mapping } \\
\text { of the trait; see also below, Body temperature } \\
\text { and Diabetes, type } 2\end{array}$ & [348] \\
\hline Behavior: anxiety, & Ctnnd2** & Schizophrenia, & CTNND2 & Positional identification of the rat gene; & {$[28,349$} \\
\hline
\end{tabular}


Table 1 Alphabetical list of diseases and related traits with their causative rat genes and the human homologs (Continued)

\begin{tabular}{|c|c|c|c|c|c|}
\hline \multicolumn{2}{|l|}{ Rat } & \multicolumn{2}{|l|}{ Human } & \multirow[t]{2}{*}{ Comments } & \multirow[t]{2}{*}{ Refer } \\
\hline Phenotype & $\begin{array}{l}\text { Causative } \\
\text { gene name }{ }^{a} \\
\text { Localisation }^{c}\end{array}$ & Phenotype & $\begin{array}{l}\text { Ortholog } \\
\text { gene name } \\
\text { Localisation }^{\mathrm{c}}\end{array}$ & & \\
\hline depression & $2,83.39 \mathrm{Mb}$ & Depressive disorder & $5 p 15.2$ & $\begin{array}{l}\text { the human gene was then associated with } \\
\text { schizophrenia and major depressive } \\
\text { disorder }\end{array}$ & 350] \\
\hline
\end{tabular}

\begin{tabular}{|c|c|c|}
\hline $\begin{array}{l}\text { Behavior: anxiety, } \\
\text { depression }\end{array}$ & $\begin{array}{l}\text { S/c6a4 } 4^{\text {ENU }} \\
10,63.15 \mathrm{Mb}\end{array}$ & Anxiety/ depression \\
\hline
\end{tabular}

\section{disorder}

depression

$10,63.15 \mathrm{Mb}$

$17 q 11.2$

Behavior: anxiety, drug

addiction

Oprl1 $\mathrm{ENU}$

3, $177.23 \mathrm{Mb}$

Behavior: autism-like symptoms

Nrxn $1^{\top}$

Autism

NRXN1

6, $14.75 \mathrm{Mb}$

Behavior: dopamine-

$\operatorname{Drd} 1^{\mathrm{ENU}}$

related brain disorders

17, $11.10 \mathrm{Mb}$

Behavior: dopamine-

Slc6a3 $3^{\mathrm{ENU}, \mathrm{T}}$ related brain disorders
Several psychiatric disorders
Behavior: drug addiction (cocaine)

Behavior: fear memory

Behavior: fear memory

Behavior: fear memory and coping

Behavior: mental illnesses
DisC $^{\top}$

$19,57.82 \mathrm{Mb}$
Mental illnsesses

DISC1

$1 \mathrm{q} 41.2$
Behavior:

neuropsychiatric disorders model
The Wistar KO mutant lacking the serotonin transporter shows anxiety, depression-related behavior and impaired object memory as well as alterations in DNA methylation of the urocortin promoter

The Wistar KO mutant lacking the nociceptin/ orphanin FQ receptor rat shows an anxietylike phenotype and is more sensitive to the rewarding effect of morphin

The SD KO mutant shows persistent nonsocial deficits, including hyperactivity, deficits in simple instrumental learning, latent inhibition, and spatial-dependent learning

The Wistar mutant carries a missense mutation that leads to a decreased transmembrane insertion of DRD1; it displays normal basic neurological parameters and locomotor activity but reduced social cognition (such as social interaction)

Two mutants are available: an F344 ENUinduced missense mutant and a targeted Wistar KO mutant; both strains show locomotor hyperactivity and impaired cognitive processes; they are excellent models for the evaluation of the effects of novel therapeutics on cognitive functions linked to the dopamine transporter

The F344 KO mutant shows reduced acquisition of cocaine self-administration compared to WT rats; see also below: Blood pressure -PAH- and Behavior, drug addiction

An SD mutant was generated using a novel method that targets the Crebbp gene in a population of neurons of the medial prefrontal cortex; the mutant shows impaired fear (remote) memory and impaired extinction learning

The SD KO mutant shows a deficit in the formation and extinction of auditory fear memory, associated with enhanced apoptosis in the hippocampus

A conditional SD KO mutant was generated, targeting output neurons and the prelimbic cortex; females exhibit deficits in acquisition and extinction of fear memory; males exhibit enhanced active-coping behavior during forced swim

The SD mutant shows changes in white matter microstructural integrity and deficits in neurite density (it recapitulates many of the neuroimaging findings seen in populations of schizophrenia); the male is more affected than the female mutant

The heterozygous SD KO mutant shows deficits in social behavior and in pro-social ultrasonic communication; however this
$[351,352]$ 
Table 1 Alphabetical list of diseases and related traits with their causative rat genes and the human homologs (Continued)

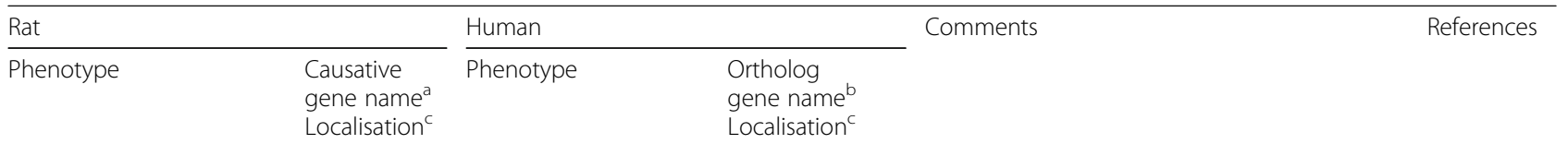

Behavior: neuropsychiatric disorders and $\mathrm{PCH} 3$ model

Behavior: stress response

Behavior: stress response

Behavior: stress response

Behavior: stress response (Stresp24)

Bladder function

$\operatorname{Trpv} 4^{\top}$

$12,47.70 \mathrm{Mb}$

Blood pressure

Blood pressure: BpQTL2

Agtria

$17 \mathrm{q} 12$,

$35.91 \mathrm{Mb}$
$\mathrm{Nrg} 1^{\top}$

$16,62.97 \mathrm{Mb}$

Stim $1^{* *}$

1, 167.37 Mb
Psychiatric and developmenta disorders and $\mathrm{PCH} 3$

PCLO

7q21.11

(GWAS) ocalisation

haploinsufficiency has a minor positive impact on memory functions

The SD KO mutant shows a reduction in the number of synaptic vesicles, which show abnormal recycling, deficient formation of early endosomes and altered synaptic transmission; the mutant displays impaired motor coordination

The DA.F344 KO congenic mutant is stressresilient and shows decreased expression of $\mathrm{Nr} 3 \mathrm{Cl}$ and $\mathrm{Fkbp5}$ in the amygdala and the hypothalamus as well as lower stress-induced peripheral corticosterone levels

The male FHH KO mutant was only used to study gene expression in the prefrontal cortex; the mutant shows reduced expression of the AMP-activated protein kinase, indicating that NR4A1 favors the adverse effects of stress; the gene also controls Parkinson disease (see above) and Renal injury (see below)

The F344 KO mutant shows alterations in HPA axis activity and behavioral responses to stress

$[366,367]$

NRG 1

$8 \mathrm{p} 12$

STIM1

$11 p 15.4$

\section{ADAMTS16} $5 \mathrm{p} 15$
Hypertension

$1,36.47 \mathrm{Mb}$

Positional identification of the gene; nonsense mutation in several SHRSP substrain alleles, absent in WKY and other normotensive strains; this mutation impairs $\mathrm{Ca}^{++}$signaling in astrocytes; this pleiotropic genes also controls Diabetes insipidus (see above), Renal injury and Stroke (see below)

The phenotype of the SD KO mutant shows that in a model of underactive bladder, intravesical activation of TRPV4 improves bladder function

The MSH6 KO mutant shows an extremely high blood pressure-like phenotype; the gene also controls Angiogenesis (see above)

Positional identification of the gene, which shows exonic variants; association between ADAMTS16 and blood pressure was then discovered in humans; KO of the gene in the SS rat leads to lower blood pressure; this gene also controls male fertility: see above, Monogenic traits, Infertility

Positional identification of the gene: missense polymorphisms in the Milan Hypertensive Rat and in humans; in vitro functional studies

Functional polymorphisms found in the rat [378] gene promoter; association was then established in the human with blood pressure and type 2 diabetes

Blood pressure

$\mathrm{Cd} 247^{\top}$

13q23,

Hypertension

1 q24 locus (GPA33, CD247, $88.88 \mathrm{Mb}$

F5, REN)

The SS KO mutant exhibits reduced kidney infiltration of T cells, mean arterial blood pressure and kidney damage

Positional identification of the gene, combined with gene expression studies; deficient renal expression of Cd36 (in SHR) is a 
Table 1 Alphabetical list of diseases and related traits with their causative rat genes and the human homologs (Continued)

\begin{tabular}{|c|c|c|c|c|c|}
\hline Rat & & Human & & Comments & References \\
\hline Phenotype & $\begin{array}{l}\text { Causative } \\
\text { gene name } \\
\text { Localisation }^{c}\end{array}$ & Phenotype & $\begin{array}{l}\text { Ortholog } \\
\text { gene name } \\
\text { Localisation }^{\mathrm{b}}\end{array}$ & & \\
\hline
\end{tabular}

$\begin{array}{ll}\text { Blood pressure } & \text { Chrm3**T } \\ \text { (C17QTL1) } & 17 q 12, \\ & 63.99 \mathrm{Mb}\end{array}$

Blood pressure

Chst $12^{* *}$ $12,18.19 \mathrm{Mb}$

Hypertension

$7 p 22$

Blood pressure

Blood pressure

Blood pressure

Blood pressure

Blood pressure

Blood pressure

Blood pressure

Blood pressure

Blood pressure

Blood pressure
Cyp $17 a 1^{*}$ 1q55, 266.42

$\mathrm{Mb}$

Cyp 11b1**
7, $112.98 \mathrm{Mb}$ genetically determined risk factor for spontaneous hypertension; the gene also controls diabetes: see below

Positional identification of the gene; the SS rat [381] carries a missense mutation enhancing receptor activity; the KO SS mutant exhibits lower salt-induced hypertension and improved renal function

Positional identification of the gene; the SS allele contains mutations when compared with several normotensive strains; this rat region is homologous to a region on human chromosome 7 that has been linked to blood pressure

AGTRAP-PLOD1 The SS KO mutant shows decreased blood locus; 1 p36

pressure; the human locus was identified in GWAS and CLCN6 could be linked to blood pressure and renal phenotypes

Positional identification of the gene; the characteristic steroid profiles of SS and SR rats can be explained by the biochemical properties of CYP11B1; 5 mutations found in the SS allele, segregating with blood pressure and altered steroid biosynthesis in a SS X SR cross

Extensive proteomics and transcriptome studies in the BN and SHR strains led to the discovery that Cyp 17a1 is downregulated in SHR, probably as a consequence of a promoter mutation; in humans a SNP in CYP17A1 was associated with hypertension

The Gja8 mutation present in the SHR-Dca strain (causing cataract; see above, Monogenic traits) lowers blood pressure and decreases high density lipoprotein cholesterol concentration

The SS KO mutant presents with lower blood pressure, accompanied by altered microbiota and improved vascular relaxation

HSD11B2 The F344 KO mutant exhibits hypertension, $16 \mathrm{q} 22.1$ hypokalemia, renal injury; the phenotype closely models the human SAME

Unlike wild-type rats, the SD KO mutant does not show reduced mean arterial pressure nor splanchnic venodilation upon serotonin infusion

The SS KO mutant exhibits protection from salt-induced blood pressure elevation

The SS KO mutant exhibits hypokalemia and reduced blood pressure; when fed on a high salt diet, this mutant dies as a result of salt wasting and severe hypokalemia; the gene also controls pH homeostasis: see above, Monogenic traits, Acidosis

Positional identification of the gene, which shows higher expression and promoter mutation in the SS rat; disruption of the gene reduces hypertension and renal oxidative 
Table 1 Alphabetical list of diseases and related traits with their causative rat genes and the human homologs (Continued)

\begin{tabular}{|c|c|c|c|c|c|}
\hline \multicolumn{2}{|l|}{ Rat } & \multicolumn{2}{|l|}{ Human } & \multirow[t]{2}{*}{ Comments } & \multirow[t]{2}{*}{ References } \\
\hline Phenotype & $\begin{array}{l}\text { Causative } \\
\text { gene name } \\
\text { Localisation }^{\mathrm{c}}\end{array}$ & Phenotype & $\begin{array}{l}\text { Ortholog } \\
\text { gene name } e^{b} \\
\text { Localisation }^{c}\end{array}$ & & \\
\hline & & & & $\begin{array}{l}\text { stress and injury; } \mathrm{Ncf2} \text { is involved in luminal } \\
\text { flow-mediated } \mathrm{O}_{2}^{--} \text {production (i.e. oxidative } \\
\text { stress) }\end{array}$ & \\
\hline Blood pressure & $\begin{array}{l}\text { Nox4 } \\
1,150.80 \mathrm{Mb}\end{array}$ & - & - & $\begin{array}{l}\text { The SS KO mutant shows reduction of salt- } \\
\text { induced hypertension and of albuminuria } \\
\text { compared with the wild-type } \mathrm{SS} \text { rat; Nox } 4 \\
\text { contributes to the production of } \mathrm{H}_{2} \mathrm{O}_{2} \text { (i.e. } \\
\text { oxidative stress) }\end{array}$ & {$[392,393]$} \\
\hline Blood pressure & $\begin{array}{l}\mathrm{Nppa}^{\top} \\
5 \mathrm{q} 36 \\
165.81 \mathrm{Mb}\end{array}$ & Hypertension & $\begin{array}{l}\text { AGTRAP-PLOD1 } \\
\text { locus; } 1 \text { p36 }\end{array}$ & $\begin{array}{l}\text { The SS KO mutant shows increased blood } \\
\text { pressure; the human locus had been identified } \\
\text { in GWAS and NPPA could be linked to blood } \\
\text { pressure phenotypes }\end{array}$ & {$[39]$} \\
\hline Blood pressure & $\begin{array}{l}N p p b^{\top} \\
5 q 36 \\
164.79 \mathrm{Mb}\end{array}$ & $\begin{array}{l}\text { Hypertension and left } \\
\text { ventricular dysfunction }\end{array}$ & $\begin{array}{l}\text { NPPB } \\
1 \mathrm{p} 36.22\end{array}$ & $\begin{array}{l}\text { The SS KO mutant shows adult-onset } \\
\text { hypertension, left ventricular hypertrophy and } \\
\text { increased cardiac stiffness }\end{array}$ & [394] \\
\hline Blood pressure & $\begin{array}{l}\mathrm{Nr} 2 \mathrm{f} 2^{\top} \\
1,131.45 \mathrm{Mb}\end{array}$ & Hypertension & $\begin{array}{l}N R 2 F 2 \\
15 q 26\end{array}$ & $\begin{array}{l}\text { NR2F2 was associated with hypertension in } \\
\text { humans; an hypomorphic SS mutant shows } \\
\text { lower systolic and diastolic blood pressures }\end{array}$ & [395] \\
\hline Blood pressure & $\begin{array}{l}\text { Pappa2** } \\
13,36.39 \mathrm{Mb}\end{array}$ & - & - & $\begin{array}{l}\text { Positional identification of the gene (including } \\
\text { generation of SS subcongenic strains); renal } \\
\text { cortex Pappa } 2 \text { mRNA level is lower in the SS } \\
\text { rat }\end{array}$ & {$[396]$} \\
\hline Blood pressure (HTNB) & $\begin{array}{l}\text { Pde } 3 a^{\top} \\
4,175.43 \mathrm{Mb}\end{array}$ & Hypertension (HTNB) & $\begin{array}{l}\text { PDE3A } \\
12 \mathrm{p} 12.2\end{array}$ & $\begin{array}{l}\text { An SD mutant carrying a } 9 \text { bp deletion similar } \\
\text { to that found in a human patient is } \\
\text { hypertensive and recapitulates HTNB } \\
\text { (including shorter fingers); the mutation } \\
\text { causes an increase in enzyme activity with } \\
\text { peripheral vascular resistance; the data } \\
\text { suggest that soluble guanylyl cyclase } \\
\text { activation could be suitable for the treatment } \\
\text { of HTNB patients }\end{array}$ & {$[46]$} \\
\hline Blood pressure & $\begin{array}{l}\text { Plekha7 } \\
1,185.43 \mathrm{Mb}\end{array}$ & Hypertension & $\begin{array}{l}\text { PLEKHA7 } \\
11 \text { p15.1 }\end{array}$ & $\begin{array}{l}\text { PLEKHA7 is a candidate gene for human } \\
\text { hypertension; the SS KO mutant shows } \\
\text { attenuated salt-sensitive hypertension and } \\
\text { vascular improvements }\end{array}$ & {$[397]$} \\
\hline Blood pressure & $\begin{array}{l}\text { Plod }^{\top} \\
5,168.38 \mathrm{Mb}\end{array}$ & Hypertension & $\begin{array}{l}\text { AGTRAP-PLOD1 } \\
\text { locus } 1 \text { p36 }\end{array}$ & $\begin{array}{l}\text { The SS KO mutant shows increased systolic } \\
\text { blood pressure; the human locus was } \\
\text { identified in GWAS }\end{array}$ & {$[39]$} \\
\hline Blood pressure & $\begin{array}{l}\operatorname{Prd} \times 2^{\top} \\
19,26.08 \mathrm{Mb}\end{array}$ & - & - & $\begin{array}{l}\text { The SHR KO mutant exhibits shorter life span } \\
\text { and modest blood pressure increase via } \\
\text { increased oxidative stress }\end{array}$ & {$[398]$} \\
\hline Blood pressure & $\begin{array}{l}\operatorname{Rag} 1^{\top} \\
3,97.87 \mathrm{Mb}\end{array}$ & SCID & $\begin{array}{l}\text { RAG1 } \\
11 \mathrm{p} 13\end{array}$ & $\begin{array}{l}\text { The SS KO mutant exhibits attenuation of } \\
\text { blood pressure and of renal damage (and } \\
\text { lymphocyte depletion: see above, Monogenic } \\
\text { traits, Immunodeficiency) }\end{array}$ & [399] \\
\hline Blood pressure & $\begin{array}{l}\text { Rarres }^{\top} \\
4,78.21 \mathrm{Mb}\end{array}$ & - & - & $\begin{array}{l}\text { The SD KO female mutant (but not the KO } \\
\text { male) exhibits a relative resistance to } \\
\text { hypertension in response to a hypertensive } \\
\text { challenge }\end{array}$ & {$[400]$} \\
\hline Blood pressure & $\begin{array}{l}\operatorname{Ren}^{\top} \\
13 \mathrm{q} 13 \\
55.55 \mathrm{Mb}\end{array}$ & - & - & $\begin{array}{l}\text { The SS KO mutant shows a greatly reduced } \\
\text { blood pressure, changes in kidney } \\
\text { morphology and reduced adrenal synthesis of } \\
\text { aldosterone and Cyp } 11 \mathrm{~b} 2\end{array}$ & {$[401,402]$} \\
\hline Blood pressure & $\begin{array}{l}\text { Resp } 18^{\top} \\
9,82.47 \mathrm{Mb}\end{array}$ & - & - & $\begin{array}{l}\text { The SS KO mutant shows increased systolic } \\
\text { and diastolic blood pressure, as well as } \\
\text { increased renal damage (Resp18 is located in a } \\
\text { blood pressure QTL) }\end{array}$ & [403] \\
\hline
\end{tabular}


Table 1 Alphabetical list of diseases and related traits with their causative rat genes and the human homologs (Continued)

\begin{tabular}{|c|c|c|c|c|c|}
\hline \multicolumn{2}{|l|}{ Rat } & \multicolumn{2}{|l|}{ Human } & \multirow[t]{2}{*}{ Comments } & \multirow[t]{2}{*}{ References } \\
\hline Phenotype & $\begin{array}{l}\text { Causative } \\
\text { gene name }{ }^{a} \\
\text { Localisation }^{c}\end{array}$ & Phenotype & $\begin{array}{l}\text { Ortholog } \\
\text { gene name }{ }^{b} \\
\text { Localisation }^{c}\end{array}$ & & \\
\hline Blood pressure & $\begin{array}{l}\text { Sh2b3 } \\
12,40.26 \mathrm{Mb}\end{array}$ & Hypertension & $\begin{array}{l}\text { SH2B3 } \\
12 q 24\end{array}$ & $\begin{array}{l}\text { SH2B3 has been associated with hypertension; } \\
\text { in the SS KO mutant, hypertension and renal } \\
\text { disease are attenuated via inflammatory } \\
\text { modulation; the gene also controls cardiac } \\
\text { inflammation: see above, Monogenic traits }\end{array}$ & [404] \\
\hline
\end{tabular}

$\begin{array}{llll}\text { Blood pressure } & \text { Sry } & \text { Hypertension } & ? \\ & Y & & Y \\ \text { Blood pressure } & \text { Zbtb16** } & - & - \\ & 8,51.57 \mathrm{Mb} & & \end{array}$
inflammation: see above, Monogenic traits

Delivery of Sry 1 CDNA to the kidney increases [405] blood pressure in normotensive WKY rats

Positional identification of the gene in RI strains and in an SHR-PD congenic; deletion in the intron 2 of the PD allele, which is downregulated and is protective; the heterozygous SHR KO mutant shows no change in blood pressure (the homozygous $\mathrm{KO}$ is lethal)

$\begin{array}{ll}\text { Blood pressure: } & \text { Ednrb** } \\ \text { captopril effects } & 15 q 22,\end{array}$

$88.00 \mathrm{Mb}$

Blood pressure: $\mathrm{PAH}$

Ddah $1^{\top}$

2, $251.63 \mathrm{Mb}$

\begin{tabular}{|c|c|c|}
\hline Blood pressure: PAH & $\begin{array}{l}K_{c} n k 3^{\top} \\
6,27.15 \mathrm{Mb}\end{array}$ & $\mathrm{PAH}$ \\
\hline Blood pressure: $\mathrm{PAH}$ & $\begin{array}{l}\text { Park } 7^{\top} \\
5,167.98 \mathrm{Mb}\end{array}$ & Familial PD (recessive) \\
\hline Blood pressure: $\mathrm{PAH}$ & $\begin{array}{l}\text { S/c39a12 }{ }^{* *^{\top}} \\
17,81.46 \mathrm{Mb}\end{array}$ & - \\
\hline Blood pressure: PAH & $\begin{array}{l}\text { Sod }^{\top} \\
14,61.07 \mathrm{Mb}\end{array}$ & - \\
\hline Blood pressure: $\mathrm{PAH}$ & 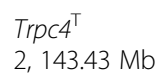 & - \\
\hline
\end{tabular}

Blood pressure and QT- Rffl-Incl *** $^{* *}$ interval 10, $71.07 \mathrm{Mb}$
KCNK3 $2 \mathrm{p} 23.3$

PARK7 1p36.23 $-$

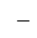

The antihypertensive effects of the ACE inhibitor captopril behave as a polygenic trait in RI strains; Ednrb was positionally identified: correlation between renal expression and captopril effects; this gene also controls aganglionosis (see above, Monogenic traits)

The SD KO mutant shows no specific phenotype under control conditions, but exhibits exacerbated monocrotaline-induced $\mathrm{PAH}$, lung fibrosis as well as right ventricule hypertrophy and dysfunction

The SD KO mutant shows predisposition to vasoconstriction of pulmonary arteries, strong alteration of right ventricular cardiomyocyte excitability and develops age-dependent PAH

The KO mutant shows a worse degree of PAH than WT rats under hypoxia; the gene also controls Parkinson disease: see above, Monogenic traits

Positional identification of the gene [WKY rats exposed to hypoxia show increased expression of S/c39a12 (ZIP12 protein)]; the KO WKY mutant shows attenuation of PAH

In the SS KO mutant, the mutation favors PAH and subsequent RV hypertrophy under stress conditions

The F344 KO mutant shows reduced severity of pulmonary arterial occlusions and survival benefit in severe PAH (the gene is also involved in Pain, see below and Behavior, drug addiction: see above)

Positional identification of the gene; the LEW allele contains a $19 \mathrm{bp}$ deletion in the long non-coding RNA (5'UTR of Rff), which increases blood pressure and shortens QTinterval relative to the SS rat ("cryptic allele"); the normal phenotypes were rescued by a specific targeted 19 bp insertion in the LEW allele

Body temperature

Cckar*

$14,59.61 \mathrm{Mb}$

$-$

Gene deletion in the OLETF rat (no mapping of the trait): the gene seems also involved in diabetes and behavior; see above, Behavior, anxiety and below Diabetes type 2

SS and SD KO mutants were studied; they show marked increases in muscle mass and 
Table 1 Alphabetical list of diseases and related traits with their causative rat genes and the human homologs (Continued)

\begin{tabular}{|c|c|c|c|c|c|}
\hline \multicolumn{2}{|l|}{ Rat } & \multicolumn{2}{|l|}{ Human } & \multirow[t]{2}{*}{ Comments } & \multirow[t]{2}{*}{ References } \\
\hline Phenotype & $\begin{array}{l}\text { Causative } \\
\text { gene name } \\
\text { Localisation }^{c}\end{array}$ & Phenotype & $\begin{array}{l}\text { Ortholog } \\
\text { gene name } \\
\text { Localisation }^{c}\end{array}$ & & \\
\hline & & & & lower fat content & \\
\hline $\begin{array}{l}\text { Body weight (liver } \\
\text { mass) }\end{array}$ & $\begin{array}{l}\text { Ogdh } \\
14,86.41 \mathrm{Mb}\end{array}$ & $\begin{array}{l}\text { Hypotonia, metabolic } \\
\text { acidosis }\end{array}$ & $\begin{array}{l}\text { OGDH } \\
7 p 13\end{array}$ & $\begin{array}{l}\text { The SD KO heterozygous mutant shows } \\
\text { increased liver weight; high fat diet results in } \\
\text { liver dysfunction (homozygous mutants are } \\
\text { lethal) }\end{array}$ & [419] \\
\hline Bone growth & $\begin{array}{l}\mathrm{Cftr}^{\top} \\
4 \mathrm{q} 21 \\
42.69 \mathrm{Mb}\end{array}$ & Cystic fibrosis & $\begin{array}{l}\text { CFTR } \\
7 \mathrm{q} 31.2\end{array}$ & $\begin{array}{l}\text { Young SD KO rats do not develop lung or } \\
\text { pancreatic disease; however, they show a } \\
\text { defect in linear bone growth and bone health } \\
\text { that is attributed to IGF-1 deficiency (for Cystic } \\
\text { fibrosis, see above, Monogenic traits) }\end{array}$ & [420] \\
\hline Bone growth & 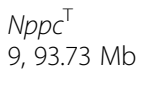 & Short stature & $\begin{array}{l}N P P C \\
2 q 37.1\end{array}$ & $\begin{array}{l}\text { The F344 KO mutant exhibits a deficit in } \\
\text { endochondral bone growth and growth } \\
\text { retardation }\end{array}$ & [421] \\
\hline $\begin{array}{l}\text { Bone structure and } \\
\text { function }\end{array}$ & $\begin{array}{l}\text { Bglap }^{\top} \\
2,87.74 \mathrm{Mb}\end{array}$ & - & - & $\begin{array}{l}\text { The SD KO mutant shows increased trabecular } \\
\text { thickness, density and volume, and increased } \\
\text { bone strength }\end{array}$ & [422] \\
\hline Brain development & $\begin{array}{l}\text { Bscl2 } 2^{\mathrm{ENU}} \\
1,225.04 \mathrm{Mb}\end{array}$ & $\begin{array}{l}\text { Congenital generalized } \\
\text { lipodystrophy }\end{array}$ & $\begin{array}{l}B S C L 2 \\
11 \mathrm{q} 12.3\end{array}$ & $\begin{array}{l}\text { The KO mutant shows a slightly decreased } \\
\text { brain weight and impairment of spatial } \\
\text { working memory; see also above, Monogenic } \\
\text { traits, Lipodystrophy, and Infertility }\end{array}$ & [223] \\
\hline Brain injury & $\begin{array}{l}\text { Aqp } 4^{\top} \\
18,6.77 \mathrm{Mb}\end{array}$ & - & - & $\begin{array}{l}\text { Following subarachnoid hemorrhage, the KO } \\
\text { mutant shows increased water content in the } \\
\text { whole brain, which aggravates the } \\
\text { neurological deficits through impairment of } \\
\text { the glymphatic system. }\end{array}$ & [423] \\
\hline $\begin{array}{l}\text { Brain injury: acute } \\
\text { cerebral infarction }\end{array}$ & $\begin{array}{l}U_{b a \sigma^{\top}} \\
14,23.51 \mathrm{Mb}\end{array}$ & - & - & $\begin{array}{l}\text { The SD conditional KO mutant specifically } \\
\text { lacks expression of the gene in the brain and } \\
\text { shows aggravation of cerebral infarction, } \\
\text { accompanied by increased level of apoptosis }\end{array}$ & [424] \\
\hline Cancer, colon & $\begin{array}{l}\text { Rffl or Rffl- } \\
\text { Inc1* } \\
10,70,16 \mathrm{Mb} \\
\text { or } 71.07 \mathrm{MB}\end{array}$ & - & - & $\begin{array}{l}\text { Positional identification of the gene(s); higher } \\
\text { expression of Rffl in S-LEW congenic rats, } \\
\text { which also show higher expression of Mbd2 } \\
\text { and higher susceptibility to colorectal } \\
\text { carcinogenesis; see above, Blood pressure and } \\
\text { QT-interval }\end{array}$ & {$[425]$} \\
\hline $\begin{array}{l}\text { Cancer, esophageal } \\
\text { carcinoma }\end{array}$ & $\begin{array}{l}\text { Mir31 } \\
5,107.21 \mathrm{Mb}\end{array}$ & - & - & $\begin{array}{l}\text { The SD KO mutant is resistant to zinc- } \\
\text { deficiency associated esophageal carcinoma } \\
\text { as a result of a strong reduction in an } \\
\text { inflammatory process }\end{array}$ & {$[426]$} \\
\hline $\begin{array}{l}\text { Cancer, mammary } \\
\text { (Mcsia) }\end{array}$ & $\begin{array}{l}\text { Putative } \\
\text { regulatory } \\
\text { site }^{* *} \\
2, \sim 6.50 \mathrm{Mb}\end{array}$ & - & - & $\begin{array}{l}\text { Positional identification of the locus; cancer } \\
\text { resistance is associated with increased } \\
\text { expression of the nearby gene Nr2fl; the } \\
\text { human homologous region ( } 5 q^{11-q 34)} \text { is } \\
\text { frequently deleted in breast cancers }\end{array}$ & {$[427]$} \\
\hline $\begin{array}{l}\text { Cancer, mammary } \\
\text { (Mcsib) }\end{array}$ & $\begin{array}{l}\text { Mier3** } \\
2,62.31 \mathrm{Mb}\end{array}$ & Breast cancer risk locus & $\begin{array}{l}\text { MAP3K1 or MIER3 } \\
5 q 11.2\end{array}$ & $\begin{array}{l}\text { Positional identification of the gene; higher } \\
\text { expression in mammary glands of susceptible } \\
\text { females }\end{array}$ & [428] \\
\hline
\end{tabular}

\begin{tabular}{|c|c|c|c|c|}
\hline $\begin{array}{l}\text { Cancer, mammary } \\
\text { (Mcs5a1) }\end{array}$ & $\begin{array}{l}\text { Fbxo10** } \\
5,60.59 \mathrm{Mb}\end{array}$ & $\begin{array}{l}\text { Breast cancer risk } \\
\text { locus }\end{array}$ & $\begin{array}{l}\text { FBXO10 } \\
\text { (MCS5A1) } \\
9 \mathrm{p} 13\end{array}$ & $\begin{array}{l}\text { Positional identification of the gene; up- } \\
\text { regulation in T cells is associated with } \\
\text { susceptibility; causal SNVs are probably } \\
\text { stress-responding regulatory sites }\end{array}$ \\
\hline $\begin{array}{l}\text { Cancer, mammary } \\
\text { (Mcs5a2) }\end{array}$ & $\begin{array}{l}\text { Frmpd1** } \\
5,60.75 \mathrm{Mb}\end{array}$ & $\begin{array}{l}\text { Breast cancer risk } \\
\text { locus }\end{array}$ & $\begin{array}{l}\text { FRMPD1 } \\
\text { (MCS5A2) 9p13 }\end{array}$ & $\begin{array}{l}\text { Positional identification of the gene; up- } \\
\text { regulation in the spleen was associated } \\
\text { with cancer resistance }\end{array}$ \\
\hline
\end{tabular}


Table 1 Alphabetical list of diseases and related traits with their causative rat genes and the human homologs (Continued)

\begin{tabular}{|c|c|c|c|c|c|}
\hline \multicolumn{2}{|l|}{ Rat } & \multicolumn{2}{|l|}{ Human } & \multirow[t]{2}{*}{ Comments } & \multirow[t]{2}{*}{ References } \\
\hline Phenotype & $\begin{array}{l}\text { Causative } \\
\text { gene name } e^{a} \\
\text { Localisation }^{c}\end{array}$ & Phenotype & $\begin{array}{l}\text { Ortholog } \\
\text { gene name } e^{b} \\
\text { Localisation }^{c}\end{array}$ & & \\
\hline & & & & $\begin{array}{l}\text { during a critical mammary developmental } \\
\text { time period }\end{array}$ & \\
\hline $\begin{array}{l}\text { Cancer, mammary } \\
\text { (Mcs30) }\end{array}$ & $\begin{array}{l}\text { Fry }^{*} \\
12,7.68 \mathrm{Mb}\end{array}$ & - & - & $\begin{array}{l}\text { Positional identification of the gene; several } \\
\text { SNPs between F344 (susceptible) and COP } \\
\text { (resistant); decreased expression of FRY in } \\
\text { human cancers }\end{array}$ & [433] \\
\hline $\begin{array}{l}\text { Cancer, mammary } \\
\text { gland development }\end{array}$ & $\begin{array}{l}C d k n 1 b^{\top} \\
4,168.69 \mathrm{Mb}\end{array}$ & $\begin{array}{l}\text { Multiple endocrine } \\
\text { neoplasia type } 4\end{array}$ & $\begin{array}{l}\text { CDKN1B } \\
12 \mathrm{p} 13.1\end{array}$ & $\begin{array}{l}\text { In humans the frequency of a population of } \\
\text { quiescent CDKN1B expressing cells was } \\
\text { associated with breast cancer risk; the } C d k n 1 b \\
\text { KO ACI rat shows increased proliferation and } \\
\text { pregnancy-associated changes in the } \\
\text { mammary gland; } C d k n 1 b \text { could impact } \\
\text { mammary cancer risk; see also above, } \\
\text { Monogenic traits, Cancer, multiple endocrine } \\
\text { neoplasia and Obesity }\end{array}$ & [83] \\
\hline Cardiac mass & $C f b^{T}$ & - & - & See below, Metabolic syndrome & [434] \\
\hline Cardiac mass (Cm10) & $\begin{array}{l}\text { Endog } \\
3,8.74 \mathrm{Mb}\end{array}$ & - & - & $\begin{array}{l}\text { Positional identification of the gene, which is } \\
\text { underexpressed in strains with increased } \\
\text { cardiac mass; exonic mutation in SHR; Endog } \\
\text { seems to be implicated in mitochondrial } \\
\text { physiology }\end{array}$ & {$[435]$} \\
\hline Cardiac mass (LVM) & $\begin{array}{l}O g n^{* *} \\
17,14.61 \\
M b\end{array}$ & LVM & $\begin{array}{l}\text { OGN } \\
9 \mathrm{q} 22.31\end{array}$ & $\begin{array}{l}\text { Localization of a QTL and genome-wide } \\
\text { gene expression studies associated } \\
\text { upregulation of Ogn (due to sequence } \\
\text { variation in the Ogn 3' UTR) with elevated } \\
\text { LVM; this finding was translated to } \\
\text { humans }\end{array}$ & {$[436]$} \\
\hline
\end{tabular}

Cardiac mass, fibrosis Z Zbtb16*,T _ $\quad \ldots \quad$ P $\quad$ Positional identification of the gene in Rl $8,51.57 \mathrm{Mb} \quad$ strains and in an SHR-PD congenic: deletion in the intron 2 of the PD allele, which is downregulated and is protective; the heterozygous SHR KO mutant shows reduced cardiomyocyte hypertrophy and interstitial fibrosis (the homozygous $\mathrm{KO}$ is lethal)

Cholesterol level and Srebfi*** Cholesterol level and SREBF1 hepatic steatosis (Hpcl1)

Positional identification of the gene; the SHR allele is associated with deficient expression of mRNA and protein; an SHR transgenic strain shows restoration of hepatic cholesterol level

CKD contributes to secondary cardiovascular impairment (cardiorenal syndrome type 4); in the surgical excision model of $5 / 6$ nephrectomy, the KO SD female mutant shows sex-specific exacerbated renal hypertrophy and fibrosis with renal dysfunction yet lower blood pressure and less pronounced cardiac remodeling

The SS mutant develops profound CKD characterized by focal necrosis and fibrosis, glomerulosclerosis, massive proteinaceous cast accumulation with tubular dilatation, interstitial fibrosis with hypertension and renal failure; see also below, Vascular function

\begin{tabular}{|c|c|c|c|}
\hline $\begin{array}{l}\text { Diabetes, type 1: } \\
\text { T1DM (Kdp1) }\end{array}$ & $\begin{array}{l}\text { Cblb*** } \\
11,51.04 \\
\mathrm{Mb}\end{array}$ & Diabetes, type 1 & $\begin{array}{l}C B L B \\
3 q 13.11\end{array}$ \\
\hline $\begin{array}{l}\text { Diabetes, type 1: T1DM } \\
(I d d m 8)\end{array}$ & $\begin{array}{l}\text { Dock8** } \\
1,242.93 \mathrm{Mb}\end{array}$ & - & - \\
\hline
\end{tabular}

Positional identification of the gene, mutated in the Komeda diabetes-prone rat; complementation with the WT gene significantly suppressed the phenotype of the KDP rats

Positional identification of the gene which harbors a missense mutation in the diabetic 
Table 1 Alphabetical list of diseases and related traits with their causative rat genes and the human homologs (Continued)

\begin{tabular}{|c|c|c|c|c|c|}
\hline Rat & & Human & & Comments & References \\
\hline Phenotype & $\begin{array}{l}\text { Causative } \\
\text { gene name } \\
\text { Localisation }^{c}\end{array}$ & Phenotype & $\begin{array}{l}\text { Ortholog } \\
\text { gene name } \\
\text { Localisation }^{c}\end{array}$ & & \\
\hline
\end{tabular}

\begin{tabular}{rlll}
\hline Diabetes, type 1: T1DM & Gimap5** & Systemic lupus & GIMAP5 \\
Lymphopenia (Iddm2/lyp) & $4,78.38 \mathrm{Mb}$ & erythematosus & $7 \mathrm{q} 36.1$
\end{tabular}

LEW.1 AR1/Ztm-idmm rat

Positional identification of the gene, mutated in the diabetes-prone BB rat; Iymphopenia is essential for the development of the diabetic phenotype; in humans, GIMAP5 could play a role in the pathogenesis of systemic lupus erythematosus

Diabetes, type 1: T1DM Ubd*, ${ }^{\top}$ (Iddm37)

20, $1.87 \mathrm{Mb}$

Diabetes, type 1: T1DM Ifnarl $^{\top} \quad$ T1DM 11, $31.64 \mathrm{Mb}$

Diabetes, type 2: T2DM

Adra2a** $1,274.77$

$\mathrm{Mb}$

Diabetes, type 2: T2DM

1, $102.11 \mathrm{Mb}$

T2DM and

Hyperinsulinemic hypoglycemia and

Diabetes, type 2: T2DM Cckar**

(Odb2)

14, 59.61 Mb
Several genes acting downstream IFNAR I

ADRA2A $10 \mathrm{q} 25.2$

$A B C C 8$

$11 \mathrm{p} 15.1$

Positional identification of Ubd, the promoter of which is polymorphic; high UBD expression is associated with virus-induced T1DM susceptibility (LEW.1WR1 rat for instance); an LEW.1WR1 KO rat shows reduced susceptibility, confirming the role of Ubd; the gene also controls cardiac ischemia (see above)

Two LEW.1WR1 KO mutants were isolated; they exhibit, as expected, an impaired response to interferon I treatment; they are partially protected against virus-induced diabetes

Positional identification of the gene, overexpressed in the diabetic GotoKakizaki rat, mediating adrenergic suppression of insulin secretion; association was then found between $A D R A 2 A$ and increased T2DM risk in humans

The SD KO mutant is glucose intolerant and shows enhanced insulin sensitivity; T2DM was induced in this mutant which was then treated with glimepiride (a sulfonylurea); the treatment decreased blood glucose levels, suggesting an extra-pancreatic, direct effect on insulin-sensitive tissues

Positional identification of the gene, deleted in the OLETF rat; mapping studies suggest an interaction with an X-linked QTL; the gene might also control pancreatic duct hyperplasia; see also above, Body temperature and Behavior, anxiety

Diabetes: T2DM

$C d 36^{* * *}$

T2DM: Insulin

CD36

(Insulin resistance and $4,14.15 \mathrm{Mb}$ hyperlipidemia)

Positional identification of the gene, combined with genome-wide gene expression studies; $C d 36$ is deleted in the SHR strain; transgenic expression of $C d 36$ in SHR ameliorates insulin resistance and lowers serum fatty acids; association of human CD36 with T2DM; the gene also controls blood pressure: see above

INPPL1

$11 q 13.4$

Diabetes, type 2:
T2DM (Nidd/gk1)

Inppl1**

T2DM

$166.90 \mathrm{Mb}$

Diabetes, type 2: T2DM Ndufa4*

(diet-induced)

4, $38.23 \mathrm{Mb}$

Positional identification of the gene, mutated in the Goto-Kakizaki diabetic rat (and the insulin-resistant SHR); mutations were then found in human diabetic patients

Positional identification of the gene, which shows a 61 bp deletion, unique to the Cohen diabetic rat; this mutation adversely affects mitochondrial function and promotes dietinduced diabetes

[442-444]

[445]

$[448,449]$

$[450,451]$ 
Table 1 Alphabetical list of diseases and related traits with their causative rat genes and the human homologs (Continued)

\begin{tabular}{|c|c|c|c|c|c|}
\hline \multicolumn{2}{|l|}{ Rat } & \multicolumn{2}{|l|}{ Human } & \multirow[t]{2}{*}{ Comments } & \multirow[t]{2}{*}{ References } \\
\hline Phenotype & $\begin{array}{l}\text { Causative } \\
\text { gene name }{ }^{a} \\
\text { Localisation }^{c}\end{array}$ & Phenotype & $\begin{array}{l}\text { Ortholog } \\
\text { gene name } e^{b} \\
\text { Localisation }^{c}\end{array}$ & & \\
\hline $\begin{array}{l}\text { (fat mass and insulin } \\
\text { resistance) }\end{array}$ & $4,147.27 \mathrm{Mb}$ & insulin resistance & $3 p 25.2$ & $\begin{array}{l}\text { shows reduced fat mass with adipocyte } \\
\text { hypertrophy and insulin resistance (the } \\
\text { homozygous mutant is lethal) }\end{array}$ & \\
\hline $\begin{array}{l}\text { Diabetes, type 2: T2DM } \\
\text { (Dmo 1) }\end{array}$ & $\begin{array}{l}\text { Prlhr** } \\
1,289.10 \mathrm{Mb}\end{array}$ & Blood pressure & $\begin{array}{l}\text { PRLHR } \\
10 \mathrm{q} 26.13\end{array}$ & $\begin{array}{l}\text { Positional identification of the gene; point } \\
\text { mutation at translation initiation codon in the } \\
\text { OLETF rat; the mutation causes hyperphagia }\end{array}$ & [455] \\
\hline Diabetes, type 2: T2DM & $\begin{array}{l}\text { Tbcldd }{ }^{\top} \\
15,85.93 \mathrm{Mb}\end{array}$ & Increased T2DM risk & $\begin{array}{l}\text { TBC1D4 } \\
13 \mathrm{q} 22.2\end{array}$ & $\begin{array}{l}\text { The Wistar KO mutant shows glucose } \\
\text { intolerance and insulin resistance }\end{array}$ & [456] \\
\hline $\begin{array}{l}\text { Diabetes, type } 2: \text { T2DM } \\
\text { (beta cell lipotoxicity) }\end{array}$ & $\begin{array}{l}T / r 4^{\top} \\
5,82.59 \mathrm{Mb}\end{array}$ & - & - & $\begin{array}{l}\text { The SD KO mutant shows delayed damage } \\
\text { induced by high-fat diet, improved beta-cell } \\
\text { function, decreased pancreatic inflammatory } \\
\text { infiltration and apoptosis; see also below, } \\
\text { Inflammation }\end{array}$ & [457] \\
\hline $\begin{array}{l}\text { Diabetes, type 2: } \\
\text { T2DM }\end{array}$ & $\begin{array}{l}\operatorname{Tpcn2} 2^{* * *} \\
1,218.42 \\
\mathrm{Mb}\end{array}$ & Fasting insulin & $\begin{array}{l}\text { TPCN2 } \\
11 \mathrm{q} 13.3\end{array}$ & $\begin{array}{l}\text { QTL was detected in a HS; differential } \\
\text { expression of Tpcn2; nonsynonymous } \\
\text { coding variant as well as other SNPs were } \\
\text { associated with fasting glucose; TPCN2 was } \\
\text { associated with fasting insulin in humans }\end{array}$ & [458] \\
\hline $\begin{array}{l}\text { Diabetes, type 2: T2DM } \\
\text { (Diabetic kidney } \\
\text { disease) }\end{array}$ & $\begin{array}{l}\operatorname{Trpc}^{\mathrm{T}} \\
8,6.81 \mathrm{Mb}\end{array}$ & $\begin{array}{l}\text { Familial focal } \\
\text { segmental } \\
\text { glomerulosclerosis }\end{array}$ & $\begin{array}{l}\text { TRPC6 } \\
11 \mathrm{q} 22.1\end{array}$ & $\begin{array}{l}\text { The results indicate that TRPC } 6 \text { channel } \\
\text { inhibition (in the SS rat background) has } \\
\text { partial renoprotective effects in diabetic rats }\end{array}$ & [459] \\
\hline Encephalo-myelitis (EAE) & $\begin{array}{l}\mathrm{Cd} 8 a^{\mathrm{ENU}} \\
4,163.99 \mathrm{Mb}\end{array}$ & - & - & The KO Lewis mutant is protected from EAE & {$[460]$} \\
\hline EAE & $\begin{array}{l}\text { Clec4d } d^{* *} \\
4,156.25 \mathrm{Mb} \\
\text { and } \\
\text { Clec4e } \\
4,156.27 \mathrm{Mb}\end{array}$ & Multiple sclerosis & - & $\begin{array}{l}\text { Positional identification of the genes; rat } \\
\text { strains expressing lower levels of Clec } 4 d \text { and } \\
\text { Clec4e on myeloid cells exhibit a drastic } \\
\text { reduction in EAE incidence; the CLEC4D/ } \\
\text { CLEC4E signaling pathway is upregulated in } \\
\text { peripheral blood mononuclear cells from MS } \\
\text { patients }\end{array}$ & [461] \\
\hline EAE & $\begin{array}{l}D / k 1^{* *} \\
6,142.74 \mathrm{Mb}\end{array}$ & $\begin{array}{l}\text { IDDM (depending of } \\
\text { parental origin) }\end{array}$ & $\begin{array}{l}D L K 1 \\
14 q 32\end{array}$ & $\begin{array}{l}\text { Parent-of-origin dependent QTL; the paternal } \\
\text { PVG risk allele predisposes to low DIk1 } \\
\text { expression }\end{array}$ & {$[462]$} \\
\hline EAE: Eae1 & $\begin{array}{l}\text { Btnl2* } \\
\text { 20p12, } 6.22 \\
\mathrm{MB} \text { and } \\
\text { RT1-Db1* } \\
\text { 20p12, } \\
6.17 \mathrm{Mb}\end{array}$ & Multiple sclerosis & $\begin{array}{l}\text { HLA-DRB1 } \\
6 \mathrm{p} 21.3\end{array}$ & $\begin{array}{l}\text { Positional identification: the two genes in the } \\
\text { MHC class II locus were identified in a HS and } \\
\text { are the best candidate variants, amongst } 3 \\
\text { candidate genes }\end{array}$ & {$[350]$} \\
\hline EAE: Eae30 & $\begin{array}{l}\operatorname{Rgma}^{*} \\
1,134.70 \\
\mathrm{Mb}\end{array}$ & Multiple sclerosis & $\begin{array}{l}\text { RGMA } \\
15 q 26.1\end{array}$ & $\begin{array}{l}\text { Positional identification of the rat gene } \\
\text { but polymorphisms of Rgma were not } \\
\text { sought; it is thus a suggestive causal gene; } \\
\text { however this result led to the discovery } \\
\text { that a SNP in RGMA is associated with } \\
\text { multiple sclerosis in humans }\end{array}$ & [463] \\
\hline EAE: Eae4 & $\begin{array}{l}\text { Vav1 } * * \\
9 q 12,8.6 \\
M b\end{array}$ & Multiple sclerosis & $\begin{array}{l}\text { VAV1 } \\
19 \mathrm{p} 13.2\end{array}$ & $\begin{array}{l}\text { Positional identification of the gene: one } \\
\text { SNP in rat exon } 1 \text { correlates with EAE } \\
\text { susceptibility and high TNF; in humans, } \\
\text { association found between VAV1 } \\
\text { haplotype (high expression) and multiple } \\
\text { sclerosis; the gene also regulates arthritis } \\
\text { (see above) }\end{array}$ & {$[341,464]$} \\
\hline EAE: Eae31; Pia32 & $\begin{array}{l}1121 r^{*} \\
1,197.00 \\
M b\end{array}$ & Multiple sclerosis & $\begin{array}{l}\text { IL21R } \\
16 \mathrm{p} 12.1\end{array}$ & $\begin{array}{l}\text { Positional identification of the rat gene } \\
\text { but polymorphisms of } I I 21 r \text { were not } \\
\text { sought; however this result led to the } \\
\text { discovery that SNP's in IL21R are } \\
\text { associated with multiple sclerosis in } \\
\text { humans }\end{array}$ & [463] \\
\hline
\end{tabular}


Table 1 Alphabetical list of diseases and related traits with their causative rat genes and the human homologs (Continued)

\begin{tabular}{|c|c|c|c|c|c|}
\hline \multicolumn{2}{|l|}{ Rat } & \multicolumn{2}{|l|}{ Human } & \multirow[t]{2}{*}{ Comments } & \multirow[t]{2}{*}{ References } \\
\hline Phenotype & $\begin{array}{l}\text { Causative } \\
\text { gene name }^{a} \\
\text { Localisation }^{c}\end{array}$ & Phenotype & $\begin{array}{l}\text { Ortholog } \\
\text { gene name } e^{b} \\
\text { Localisation }^{c}\end{array}$ & & \\
\hline EAE: Eae29; Pia8 & $\begin{array}{l}1122 \mathrm{ra2} 2^{* *} \\
1,15.09 \mathrm{Mb}\end{array}$ & Multiple sclerosis & $\begin{array}{l}\text { IL22RA2 } \\
6 \mathrm{q} 23.3\end{array}$ & $\begin{array}{l}\text { The susceptible strain DA carries a unique } \\
\text { variant of the gene, which is differently } \\
\text { expressed; a SNP in IL22RA2 was } \\
\text { associated with multiple sclerosis in } \\
\text { humans }\end{array}$ & {$[330,465]$} \\
\hline $\begin{array}{l}\text { Experimental } \\
\text { autoimmune neuritis: } \\
\text { Ean6 }\end{array}$ & $\begin{array}{l}\mathrm{Ncf}^{*} \\
12,25.50 \mathrm{Mb}\end{array}$ & $\begin{array}{l}\text { Guillain-Barré } \\
\text { syndrome }\end{array}$ & - & $\begin{array}{l}\text { Positional identification of the gene, a } \\
\text { suggestive causal gene: no polymorphism } \\
\text { between strains was sought but functional } \\
\text { studies support the role of Ncf1 (the gene also } \\
\text { controls EAE and PIA: see above) }\end{array}$ & {$[466]$} \\
\hline $\begin{array}{l}\text { Epilepsy (idiopathic, } \\
\text { generalized; GAERS) }\end{array}$ & $\begin{array}{l}\text { Cacna1h** } \\
10,14.73 \mathrm{Mb}\end{array}$ & Absence epilepsy & $\begin{array}{l}\text { CACNA1H } \\
16 \mathrm{p} 13.3\end{array}$ & $\begin{array}{l}\text { Direct sequencing of the gene showed a } \\
\text { mutation in the Genetic Absence Epilepsy Rats } \\
\text { from Strasbourg (and not in non-epileptic } \\
\text { strains); in an F2 cross, the phenotype } \\
\text { segregates with the mutation }\end{array}$ & {$[467]$} \\
\hline Epilepsy, tremor & $\begin{array}{l}\mathrm{Hen} 1^{* *,} \mathrm{~T} \\
2,50.10 \mathrm{Mb}\end{array}$ & $\begin{array}{l}\text { Infantile epileptic } \\
\text { encephalopathy }\end{array}$ & $\begin{array}{l}\text { HCN1 } \\
5 \mathrm{p} 12\end{array}$ & 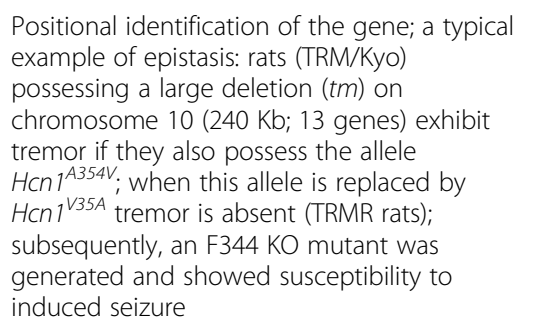 & {$[468,469]$} \\
\hline $\begin{array}{l}\text { Glomerulonephritis } \\
\text { (Crgn8) }\end{array}$ & $\begin{array}{l}C p^{* *} \\
2,104.74 \mathrm{Mb}\end{array}$ & - & - & $\begin{array}{l}\text { Positional identification of the gene in } \\
\text { combination with genome-wide eQTL } \\
\text { mapping and functional tests; ceruloplasmin is } \\
\text { overexpressed in WKY macrophages }\end{array}$ & {$[470]$} \\
\hline $\begin{array}{l}\text { Glomerulonephritis } \\
\text { (Crgn1) }\end{array}$ & $\begin{array}{l}\text { Fcgr3-rs** } \\
13,89.38 \\
\mathrm{Mb}\end{array}$ & $\begin{array}{l}\text { Glomerulonephritis } \\
\text { in systemic lupus } \\
\text { erythematosus }\end{array}$ & $\begin{array}{l}\text { FCGR3B } \\
1 \mathrm{q} 23.3\end{array}$ & $\begin{array}{l}\text { Positional identification of the loss of an } \\
\text { Fcgr3 paralog as a determinant of } \\
\text { glomerulonephritis in WKY rats; } \\
\text { expressing the gene in primary WKY } \\
\text { macrophages results in low levels of } \\
\text { phagocytosis; in humans, association } \\
\text { found between low copy number of } \\
\text { FCGR3B and lupus nephritis }\end{array}$ & {$[471,472]$} \\
\hline $\begin{array}{l}\text { Glomerulonephritis } \\
\text { (Crgn2) }\end{array}$ & $\begin{array}{l}\text { Jund }{ }^{* *} \\
16,20.48 \mathrm{Mb}\end{array}$ & - & - & $\begin{array}{l}\text { Localization of a QTL and genome-wide gene } \\
\text { expression studies associated upregulation of } \\
\text { Jund (due to a SNP in the promoter region) } \\
\text { with glomerulonephritis; Jund KO in primary } \\
\text { macrophages led to reduced macrophage } \\
\text { activity }\end{array}$ & [473] \\
\hline Glomerulonephritis & $\begin{array}{l}\text { Kcnn } 4^{* *} \\
1,81.22 \mathrm{Mb}\end{array}$ & - & - & $\begin{array}{l}\text { Genome-wide eQTL mapping in macrophages } \\
\text { from a segregating population led to the } \\
\text { identification of Kcnn4 as a key regulator of } \\
\text { macrophage multinucleation and } \\
\text { inflammatory diseases; Kcnn } 4 \text { is trans- } \\
\text { regulated by Trem2 }\end{array}$ & {$[474]$} \\
\hline Glucose homeostasis & $\begin{array}{l}\text { Tbcld } 1^{\top} \\
14,45.60 \mathrm{Mb}\end{array}$ & CAKUT & $\begin{array}{l}\text { TBC1D1 } \\
4 p 14\end{array}$ & $\begin{array}{l}\text { The SD KO mutant shows impaired } \\
\text { contraction-induced sarcolemmal glucose } \\
\text { transporter } 4 \text { redistribution, impaired glucose- } \\
\text { tolerance and reduced pancreatic beta-cell } \\
\text { mass }\end{array}$ & {$[475-477]$} \\
\hline Heart failure & $\begin{array}{l}\text { Ephx2** } \\
15,42.76 \mathrm{Mb}\end{array}$ & - & - & $\begin{array}{l}\text { Localization of a QTL and genome-wide gene } \\
\text { expression studies associated upregulation of } \\
\text { Ephx2 (due to a sequence variation in the } \\
\text { promoter region) with heart failure } \\
\text { susceptibility }\end{array}$ & {$[478]$} \\
\hline
\end{tabular}


Table 1 Alphabetical list of diseases and related traits with their causative rat genes and the human homologs (Continued)

\begin{tabular}{|c|c|c|c|c|}
\hline \multicolumn{2}{|l|}{ Rat } & \multicolumn{2}{|l|}{ Human } & \multirow[t]{2}{*}{ Comments } \\
\hline Phenotype & $\begin{array}{l}\text { Causative } \\
\text { gene name }{ }^{a} \\
\text { Localisation }^{c}\end{array}$ & Phenotype & $\begin{array}{l}\text { Ortholog } \\
\text { gene name }{ }^{b} \\
\text { Localisation }^{c}\end{array}$ & \\
\hline $\begin{array}{l}\text { Herpes simplex } \\
\text { encephalitis } \\
\text { susceptibility: Hsel }\end{array}$ & $\begin{array}{l}\text { Calcr* } \\
4 q 13 \\
28.53 \mathrm{Mb}\end{array}$ & - & - & $\begin{array}{l}\text { Differences in expression level of Calcr mRNA } \\
\text { and in protein localization between the } \\
\text { susceptible (DA) and resistant (PVG) strains }\end{array}$ \\
\hline Hippocampus function & $\begin{array}{l}\text { Trpm4 } \\
1,101.29 \mathrm{Mb}\end{array}$ & - & - & $\begin{array}{l}\text { The SD KO mutant shows a distinct deficit in } \\
\text { spatial working and spatial memory as well as } \\
\text { changes in various target regions of the right } \\
\text { dorsal hippocampus upon stimulation of } \\
\text { Schaffer collaterals }\end{array}$ \\
\hline $\begin{array}{l}\text { Inflammation: Irf7- } \\
\text { driven inflammatory } \\
\text { network }\end{array}$ & $\begin{array}{l}\text { Gpr183** } \\
15 q 15 \\
108.36 \mathrm{Mb}\end{array}$ & IDDM & $\begin{array}{l}\text { GPR183 } \\
13 q 32\end{array}$ & $\begin{array}{l}\text { Gene expression analyses and QTL } \\
\text { mapping done in the rat; the results were } \\
\text { translated to humans, identifying GPR } 183 \\
\text { (=EBI2) as a type } 1 \text { diabetes susceptibility } \\
\text { gene }\end{array}$ \\
\hline $\begin{array}{l}\text { Inflammation: TNF } \\
\text { induction }\end{array}$ & $\begin{array}{l}T / r 4^{\top} \\
5,86.69 \mathrm{Mb}\end{array}$ & - & - & $\begin{array}{l}\text { The Wistar KO rat shows markedly reduced } \\
\text { TNF induction upon liposaccharide challenge; } \\
\text { see also above, Diabetes, type } 2\end{array}$ \\
\hline Insulin resistance & Pparg** & & & See above, Diabetes type2, Fat mass \\
\hline $\begin{array}{l}\text { Macrophage } \\
\text { development }\end{array}$ & $\begin{array}{l}\text { Csfir } \\
18,56.41 \mathrm{Mb}\end{array}$ & ALSP & $\begin{array}{l}\text { CSF1R } \\
5 q 32\end{array}$ & $\begin{array}{l}\text { The DA KO mutant shows multiple } \\
\text { abnormalities: loss of macrophages in several } \\
\text { organs, osteopetrosis, infertility, lack of tooth } \\
\text { eruption, loss of visceral fat, absence of } \\
\text { microglia; see above, Mongenetic traits, } \\
\text { toothless for mutation in Csf1 }\end{array}$ \\
\hline Macrophage function & $\begin{array}{l}\text { Cyp2j4 } \\
5,119.55 \mathrm{Mb}\end{array}$ & - & - & $\begin{array}{l}\text { The WKY KO mutant macrophages show a } \\
\text { profibrotic transcriptome; the macrophage } \\
\text { epoxygenase could thus play a role in fibrotic } \\
\text { disorders with inflammatory component; see } \\
\text { also below, Metabolic syndrome }\end{array}$ \\
\hline $\begin{array}{l}\text { Metabolic syndrome } \\
\text { (Niddm30) }\end{array}$ & $\begin{array}{l}\text { Camk2n1 } \\
5,156.88 \mathrm{Mb}\end{array}$ & $\begin{array}{l}\text { Elevated risk of T2DM } \\
\text { and coronary heart } \\
\text { disease }\end{array}$ & $\begin{array}{l}\text { CAMK2N1 } \\
1 \mathrm{p} 36.12\end{array}$ & $\begin{array}{l}\text { The gene was a solid candidate gene for } \\
\text { metabolic syndrome (blood pressure, diabetes, } \\
\text { left ventricule weight); the SHR KO rat shows } \\
\text { reduced cardiorenal Camk2 activity, lower } \\
\text { blood pressure, lower left ventricular mass, } \\
\text { decreased visceral fat mass and increased } \\
\text { insulin sensitivity }\end{array}$ \\
\hline
\end{tabular}

$\begin{array}{llll}\text { Metabolic syndrome } & C f b^{\top} & \text { NIDDM and } & C F B \\ & 20 \mathrm{p} 12, & \text { components of } & 6 \mathrm{p} 21.33 \\ & 4.54 \mathrm{Mb} & \text { metabolic syndrome } & \end{array}$

Metabolic syndrome

Cyp2j4 $4^{\top}$

$5,119.55 \mathrm{Mb}$

Metabolic syndrome Folh $1^{* *}$

1, $150.32 \mathrm{Mb}$

Metabolic syndrome
Folr $7^{* * *}$
1, $166.93 \mathrm{Mb}$

The SHR KO rat shows improved glucose tolerance and adipose distribution, lower blood pressure, and reduced left ventricular mass; several human SNPs in CFB were associated with cardiometabolic traits

The WKY KO mutant shows adipocyte hypertrophy and weight gain; under "cafetaria diet", it shows hepatic lipid accumulation, dysregulated gluconeogenesis and increased triglyceride levels; see also above, Macrophage function

Positional identification of the gene; the SHR allele shows 2 missense mutations; an SHR congenic line harboring the BN Folh1 allele shows decreased glucose and insulin concentrations

Positional identification of the gene, the promoter of which is mutated in the SHR; transgenic rescue experiments ameliorate most of the metabolic disturbances, probably linked to folate deficiency and hypercysteinemia 
Table 1 Alphabetical list of diseases and related traits with their causative rat genes and the human homologs (Continued)

\begin{tabular}{|c|c|c|c|c|c|}
\hline \multicolumn{2}{|l|}{ Rat } & \multicolumn{2}{|l|}{ Human } & \multirow[t]{2}{*}{ Comments } & \multirow[t]{2}{*}{ References } \\
\hline Phenotype & $\begin{array}{l}\text { Causative } \\
\text { gene name } e^{a} \\
\text { Localisation }^{c}\end{array}$ & Phenotype & $\begin{array}{l}\text { Ortholog } \\
\text { gene name } e^{b} \\
\text { Localisation }^{c}\end{array}$ & & \\
\hline Metabolic syndrome & $\begin{array}{l}\text { Gja8**2, } \\
199.05 \mathrm{Mb}\end{array}$ & - & - & $\begin{array}{l}\text { The Gja8 mutation present in the SHR-Dca } \\
\text { strain causes dominant cataract (see above, } \\
\text { Monogenic traits); in the heterozygous form } \\
\text { this mutation results in increased } \\
\text { concentration of triacyl-glycerols, decrease of } \\
\text { cholesterol and elevation of inflammatory } \\
\text { cytokines }\end{array}$ & [489] \\
\hline Metabolic syndrome & $\begin{array}{l}\text { Mt-Nd2, Mt- } \\
N d 4, M t-N d 5\end{array}$ & - & - & $\begin{array}{l}\text { The conplastic rat SHR-mt }{ }^{\mathrm{LEW}} \text { only differs from } \\
\text { SHR in the sequence of these } 3 \text { mitochondrial } \\
\text { genes and exhibits increased serum fatty acid } \\
\text { levels and resistance to insulin stimulated } \\
\text { incorporation of glucose into adipose tissue } \\
\text { lipids }\end{array}$ & [490] \\
\hline Metabolic syndrome & $\begin{array}{l}\text { Wars2*** } \\
2 \mathrm{q} 34 \\
201.17 \mathrm{Mb}\end{array}$ & $\begin{array}{l}\text { Cardio-metabolic } \\
\text { phenotypes }\end{array}$ & $\begin{array}{l}\text { WARS2 } \\
1 \mathrm{p} 12\end{array}$ & $\begin{array}{l}\text { Positional identification of the gene; the SHR } \\
\text { allele is mutated (and causes reduced } \\
\text { angiogenesis - see above); transgenic SHR- } \\
\text { Wars2 rats exhibit increased glucose oxidation } \\
\text { and incorporation into brown adipose tissue, } \\
\text { as well as lower adiposity }\end{array}$ & [491] \\
\hline Metabolic syndrome & $\begin{array}{l}\text { Zbtb16 } \\
8,51.57 \mathrm{Mb}\end{array}$ & - & - & $\begin{array}{l}\text { The heterozygous SHR KO rat exhibits lower } \\
\text { serum and triglycerides and cholesterol as } \\
\text { well as increased sensitivity to adipose and } \\
\text { muscle tissue to insulin action }\end{array}$ & {$[407]$} \\
\hline $\begin{array}{l}\text { Metabolic syndrome: } \\
\text { obesity }\end{array}$ & $\begin{array}{l}\text { Aqp } 11^{* *} \\
1,162.70 \mathrm{Mb}\end{array}$ & - & - & $\begin{array}{l}\text { Positional identification of the gene in } \\
\text { combination with expression QTL mapping; } \\
\text { the LH rat allele is mutated in the } 3^{\prime} \text { UTR and } \\
\text { the } 5^{\prime} \text { upstream region; downregulation of } \\
\text { Aap } 11 \text { is associated with obesity in the LH rat; } \\
\text { aquaporins are now considered to be } \\
\text { involved in adipose tissue homeostasis }\end{array}$ & [492] \\
\hline Metabolism & $\begin{array}{l}\text { Apoa4 } \\
8 \mathrm{q} 23 \\
50.54 \mathrm{Mb}\end{array}$ & - & - & $\begin{array}{l}\text { The SD KO mutant shows improved glucose } \\
\text { tolerance and altered expression of genes } \\
\text { expressed in the liver, with enhanced } \\
\text { glycolysis, attenuated gluconeogenesis and } \\
\text { elevated de novo lipogenesis }\end{array}$ & [493] \\
\hline Metabolism & $\begin{array}{l}E s r 1^{\top} \\
1 \mathrm{q} 12 \\
41.19 \mathrm{Mb}\end{array}$ & - & - & $\begin{array}{l}\text { The male SD KO liver shows altered } \\
\text { expression of genes involved in carbohydrate } \\
\text { and lipid metabolism; see also above, } \\
\text { Monogenic traits, Infertility }\end{array}$ & [494] \\
\hline Metabolism & $\begin{array}{l}P_{m c h}^{E N U} \\
7,28.65 \mathrm{Mb}\end{array}$ & - & - & $\begin{array}{l}\text { The Wistar KO mutant is lean, hypophagic, } \\
\text { osteoporotic and has a low adipose mass due } \\
\text { to a lower adipocyte cell size }\end{array}$ & {$[495,496]$} \\
\hline $\begin{array}{l}\text { Metabolism (steroid } \\
\text { synthesis) }\end{array}$ & $\begin{array}{l}\text { Tspo' } \\
7,124.46 \mathrm{Mb}\end{array}$ & $\begin{array}{l}\text { Anxiety-related } \\
\text { disorders }\end{array}$ & TSPO & $\begin{array}{l}\text { The SD KO mutant displays impaired ACTH- } \\
\text { induced steroid production and reduced } \\
\text { circulating testosterone levels; in humans a } \\
\text { rare TSPO allele is associated with a reduced } \\
\text { plasma cortisol rate of formation }\end{array}$ & [497] \\
\hline $\begin{array}{l}\text { Neuromyelitis optica } \\
\text { spectrum disorders }\end{array}$ & $\begin{array}{l}\mathrm{Cd} 59^{\top} \\
3,94.01 \mathrm{Mb}\end{array}$ & - & - & $\begin{array}{l}\text { The SD KO mutant shows no overt } \\
\text { phenotype, except for mild hemolysis; } \\
\text { however upon intracerebral administration of } \\
\text { autoantibodies against astrocyte aquaporin 4, } \\
\text { it shows marked neuromyelitis optica } \\
\text { pathology including inflammation and } \\
\text { demyelination }\end{array}$ & [498] \\
\hline $\begin{array}{l}\text { Non-alcoholic fatty liver } \\
\text { disease }\end{array}$ & $\begin{array}{l}\text { Pten }^{\top} \\
\text { 1, 251.42 Mb }\end{array}$ & - & - & $\begin{array}{l}\text { This study reports the somatic inactivation of } \\
\text { Pten in the liver (by injection of an } \\
\text { inactivating plsmid); the treated SD rats } \\
\text { showed increased body weight and } \\
\text { triglyceride level, with increased lipid }\end{array}$ & [499] \\
\hline
\end{tabular}


Table 1 Alphabetical list of diseases and related traits with their causative rat genes and the human homologs (Continued)

\begin{tabular}{|c|c|c|c|c|c|}
\hline \multicolumn{2}{|l|}{ Rat } & \multicolumn{2}{|l|}{ Human } & \multirow[t]{2}{*}{ Comments } & \multirow[t]{2}{*}{ References } \\
\hline Phenotype & $\begin{array}{l}\text { Causative } \\
\text { gene name } \\
\text { Localisation }^{c}\end{array}$ & Phenotype & $\begin{array}{l}\text { Ortholog } \\
\text { gene name } \\
\text { Localisation }^{\mathrm{c}}\end{array}$ & & \\
\hline
\end{tabular}

$\begin{array}{ll}\begin{array}{ll}\text { Oxidative stress- } \\ \text { mediated cell death }\end{array} & \text { Keap } T^{\top} \\ & 8,22.25 \mathrm{Mb} \\ & \\ \text { Pain } & \text { Scn9aT e } \\ & 3,52.58 \mathrm{Mb} \\ & \\ & \\ \text { Pain } & \text { Trpv } 1^{\top} \\ & 10,59.80 \mathrm{Mb}\end{array}$

accumulation in the liver

Grafting of mesenchymal stem cells is

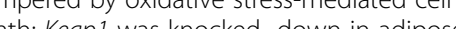
. Keapl was knocked- down in adiposederived mesenchymal stem cells leading to the activation of NFE2L2 and lower oxidative stress

The SD KO ${ }^{e}$ rat does not exhibit nociceptive pain responses in hot plate nor neuropathic pain responses following spinal nerve ligation; inhibition of SCN9A in humans may thus reduce pain in neuropathic conditions

Neuroimaging experiments of SD KO and WT rats showed that capsaicin-induced pain activates neuronal circuitries involved in pain but also in emotion and memory in a TRPV1dependent manner; this channel was shown to be dispensable for hypernatremia-induced vasopressin secretion

Pain (visceral

nociception)

$\operatorname{Trpc} 4^{\top}$

2, $143.43 \mathrm{Mb}$

Pain processing

$\mathrm{Ano3}^{\mathrm{T}}$

3, $108.44 \mathrm{Mb}$

Proteinuria (Pur 1)

Actr3**13, $46.81 \mathrm{Mb}$

Proteinuria

Proteinuria

Proteinuria

Proteinuria

Plod 1

Agtrap $^{\top}$ 5, $168.55 \mathrm{Mb}$

Renal function

$\mathrm{Clcn6}^{\mathrm{T}}$

5, $168.47 \mathrm{Mb}$

Renal function

Mthfr ${ }^{\mathrm{T}}$

5, $168.50 \mathrm{Mb}$

Renal function

Proteinuria (Rf2)

Proteinuria and kidney damage

$\operatorname{Add}^{* * *}$

$273.85 \mathrm{Mb}$

Proteinuria and kidney damage (Rf4)
Shroom3**

$14,16.62 \mathrm{Mb}$
Renal function

SHROOM3 (GWAS) $4 \mathrm{q} 21.1$
The F344 KO rat is tolerant to noxious chemical stimuli applied to the colon (the gene is also involved in Blood pressure control -PAH- and Behavior, drug addiction: see above)

The F344 KO rat shows increased neuronal activity and increased thermal and mechanical sensitivity

Positional identification of the gene: sole gene mutated in the Purl interval of the BUF/Mna rat (a model of glomerulosclerosis)

AGTRAP-PLOD1 The SS KO rat shows decreased urinary locus; 1 p36 protein excretion; the human locus had been identified in GWAS

AGTRAP-PLOD1 The SS KO rat shows decreased urinary locus; 1 p36 protein excretion; the human locus had been identified in GWAS

AGTRAP-PLOD1 The SS KO rat shows increased urinary protein locus; $1 \mathrm{p} 36$ excretion; the human locus had been identified in GWAS and MTHFR could be linked to blood pressure and renal phenotype

AGTRAP-PLOD1 The SS KO rat shows increased urinary protein locus; 1 p36 excretion; the human locus had been identified in GWAS

Natural $\mathrm{KO}$ in $\mathrm{FHH}$; transgenesis in $\mathrm{FHH}$ and targeted $\mathrm{KO}$ in a FHH.BN congenic demonstrated the role of Rab38 in protein excretion

Positional identification and sequencing of the $\mathrm{FHH}$ gene revealed a deleterious mutation; knockout and transgenesis experiments confirmed the causal role of the mutation

Congenic mapping and sequence analysis in rats suggested that Shroom3 was a strong positional candidate gene; variants disrupting the actin-binding domain of SHROOM3 may cause podocyte effacement and impairment of the glomerular filtration barrier in zebrafish 
Table 1 Alphabetical list of diseases and related traits with their causative rat genes and the human homologs (Continued)

\begin{tabular}{|c|c|c|c|c|c|}
\hline \multicolumn{2}{|l|}{ Rat } & \multicolumn{2}{|l|}{ Human } & \multirow[t]{2}{*}{ Comments } & \multirow[t]{2}{*}{ References } \\
\hline Phenotype & $\begin{array}{l}\text { Causative } \\
\text { gene name }^{a} \\
\text { Localisation }^{c}\end{array}$ & Phenotype & $\begin{array}{l}\text { Ortholog } \\
\text { gene name } e^{b} \\
\text { Localisation }^{c}\end{array}$ & & \\
\hline $\begin{array}{l}\text { Proteinuria and kidney } \\
\text { damage }\end{array}$ & $\begin{array}{l}T^{T f b}{ }^{\top} \\
1,83.74 \mathrm{Mb}\end{array}$ & - & - & $\begin{array}{l}\text { Heterozygous KO of Tgfb protects the SS rat } \\
\text { against high salt-induced renal injury }\end{array}$ & [511] \\
\hline $\begin{array}{l}\text { Proteinuria and kidney } \\
\text { damage }\end{array}$ & $\begin{array}{l}\text { Tmem63c* } \\
\text { 6, } 111.04 \mathrm{Mb}\end{array}$ & - & - & $\begin{array}{l}\text { Positional identification of the gene, which } \\
\text { shows differential glomerular expression; the } \\
\text { susceptible strain (MWF) also shows a } \\
\text { nephron deficit; patients with focal segmental } \\
\text { glomerulosclerosis exhibit loss of glomerular } \\
\text { TMEM63C expression }\end{array}$ & [512] \\
\hline
\end{tabular}

\section{Proteinuria and kidney damage} (Pur7?)

Proteinuria and kidney disease $(R f 1)$

\section{Arhgef11** 2, 206.39 $\mathrm{Mb}$ \\ Sorcs 1 **T \\ $1,277.40$ \\ $\mathrm{Mb}$}

\section{QT-interval}

Renal injury

Renal injury

Renal injury

Rheumatoid factor production

Spermatogenesis

$\operatorname{Tp53}$

10q24,

$56.19 \mathrm{Mb}$

Stroke

$\operatorname{lgh}^{*}$

$6, \sim 138 \mathrm{Mb}$

Rffl-InCl ${ }^{* * *}$

$\mathrm{Nr} 4 a 1^{\top}$

Serpinc $T^{\top}$

$13,78.81 \mathrm{Mb}$

Stiml*** $167.37 \mathrm{M}$

$|g| * *$

$11,83.93 \mathrm{Mb}$

\section{1q21 rate}

Kidney disease

SORCS1 10q23-q25

7, $142.90 \mathrm{Mb}$

Autoimmunity

STIM1

$11 \mathrm{p} 15.4$

Li-Fraumeni syndrome

TP53

$17 p 13.1$

Stroke (Str1)

Ndufc2*T

Stroke
Positional identification of the gene; allelic variants are differentially expressed in SS, SHR and congenic rats

The $R f 1$ interval was narrowed down to a single gene, Sorcs 1 , which only shows polymorphisms in non-coding regions; Sorcs 1 KO in the consomic FHH- ${ }^{\text {BN }}$ causes increased proteinuria and impairment of albumin transport; in humans, association was found between SORCS1 and kidney disease

See above, Blood pressure and QT-interval

The FHH KO rat shows early onset of kidney injury and progressive decline in kidney function resulting from macrophage-mediated enhanced inflammatory processes; the gene is also involved in dyskinesia (see above, Monogenic traits, Parkinson disease model) and in Behavior, Stress response (see above)

Patients with low SERPINC1 activities present a higher risk of developing AKI after cardiac surgery; the heterozygous congenic SS.BN KO rat shows increased renal injury after renal ischemia/reperfusion

Genome sequencing revealed a deletion affecting the Stiml gene is the SHR-A3 which develops renal injury; a congenic line with a functional Stim 1 gene shows an improved lymphocyte function and a strong reduction in renal injury and glomerular immunoglobulin deposition; this pleiotropic genes also controls Diabetes insipidus (see above, Monogenic traits), Behavior (stress response, see above, Polygenic traits) and Stroke (see below)

Analysis of congenic and advanced intercrossed rats showed that the lgl locus controls rheumatoid factor production and allergic bronchitis

The SD KO mutant shows testicular atrophy, spontaneous spermatocyte death and germ cell depletion; Tp53 also controls Cancer development: see above, Monogenic traits

Congenic substitution of the SHRSP Igh locus with the corresponding haplotype from SHR (stroke-resistant) reduced cerebrovascular disease, as well as the serum levels of autoantibodies to key cerebrovascular stress proteins

Positional identification of the gene and 
Table 1 Alphabetical list of diseases and related traits with their causative rat genes and the human homologs (Continued)

\begin{tabular}{|c|c|c|c|c|c|}
\hline \multicolumn{2}{|l|}{ Rat } & \multicolumn{2}{|l|}{ Human } & \multirow[t]{2}{*}{ Comments } & \multirow[t]{2}{*}{ References } \\
\hline Phenotype & $\begin{array}{l}\text { Causative } \\
\text { gene name } \\
\text { Localisation }^{c}\end{array}$ & Phenotype & $\begin{array}{l}\text { Ortholog } \\
\text { gene name }{ }^{b} \\
\text { Localisation }^{c}\end{array}$ & & \\
\hline & $\mathrm{Mb}$ & & & $\begin{array}{l}\text { down-regulated in SHRSP (no sequence } \\
\text { difference between SHRSP and SHRSR); the } \\
\text { heterozygous SHRSR KO rat shows stroke } \\
\text { occurrence and renal abnormalities, } \\
\text { similarly to the SHRSP rat; in humans, } \\
\text { association was found between NDUFC2 } \\
\text { and stroke }\end{array}$ & \\
\hline Stroke (Str2) & $\begin{array}{l}\text { Nppa** } \\
5,165.81 \\
\text { Mb }\end{array}$ & Stroke & $\begin{array}{l}\text { NPPA } \\
1 \mathrm{p} 36.21\end{array}$ & $\begin{array}{l}\text { Positional identification of the gene; } \\
\text { altered sequence and expression of Nppa } \\
\text { in the SHRSP rat; in humans, association } \\
\text { was found between NPPA and stroke }\end{array}$ & {$[521,522]$} \\
\hline Stroke & $\begin{array}{l}\text { Stiml } 1^{* * *} \\
1,167.37 \mathrm{Mb}\end{array}$ & Autoimmunity & $\begin{array}{l}\text { STIM1 } \\
11 \text { p15.4 }\end{array}$ & $\begin{array}{l}\text { Genome sequencing revealed a deletion } \\
\text { affecting the Stim1 gene is a stroke-prone } \\
\text { subline (SHR-A3); a congenic line with a } \\
\text { functional Stim1 gene shows a strong } \\
\text { reduction in stroke susceptibility; Stim1 } \\
\text { deficiency results in the generation of auto- } \\
\text { antibodies; this pleiotropic genes also controls } \\
\text { Diabetes insipidus (see above, Monogenic } \\
\text { traits), Behavior (stress response) and Renal } \\
\text { injury (see above, Polygenic traits) }\end{array}$ & [523] \\
\hline $\begin{array}{l}\text { Stroke: neuronal } \\
\text { apoptosis }\end{array}$ & $\begin{array}{l}K I f 5^{\top} \\
15,83.70 \mathrm{Mb}\end{array}$ & - & - & $\begin{array}{l}\text { The SD KO rat with induced ischemic stroke } \\
\text { shows reduction of infarct size and of } \\
\text { apoptotic neuronal loss; KLF5 stimulates } \\
\text { stroke-induced neuronal apoptosis }\end{array}$ & {$[524]$} \\
\hline $\begin{array}{l}\text { Stroke: neuronal } \\
\text { apoptosis }\end{array}$ & $\begin{array}{l}\text { Mir195 } \\
10,56.84 \mathrm{Mb}\end{array}$ & - & - & $\begin{array}{l}\text { The SD KO rat with induced ischemic stroke } \\
\text { shows increased infarct size and apoptotic } \\
\text { neuronal loss; Mir195 down-regulates KIf5 } \\
\text { expression }\end{array}$ & [524] \\
\hline T-cell differentiation & $\begin{array}{l}\text { Pont }^{\top} \\
4,30.25 \mathrm{Mb}\end{array}$ & - & - & $\begin{array}{l}\text { The SD KO rat shows a decrease in } \mathrm{CD}^{+}{ }^{+} \\
\mathrm{CD} 8^{+} \text {and double-positive T-cells; PON1 } \\
\text { prevents excessive apoptosis by inhibiting } \\
\text { activation of the p38 signaling pathway }\end{array}$ & {$[525]$} \\
\hline T-cell differentiation & $\begin{array}{l}\text { Tap2** } \\
20 \mathrm{p} 12 \\
3.99 \mathrm{Mb} \\
+R T 1-A^{* *} \\
20 \mathrm{p} 12, ? \mathrm{Mb}\end{array}$ & - & - & $\begin{array}{l}\text { Positional identification of Tap2 and RT1-A, } \\
\text { which interact with one another and control } \\
\text { CD4:CD8 ratio and MHC class expression }\end{array}$ & {$[526]$} \\
\hline Toxicity & $\begin{array}{l}A h r^{\top} \\
6,54.97 \mathrm{Mb}\end{array}$ & - & - & $\begin{array}{l}\text { The SD KO mutant shows renal pathology and } \\
\text { lack of responses to dioxin exposure (Ahr KO } \\
\text { results in distinct phenotypes in mouse and } \\
\text { rat) }\end{array}$ & {$[527]$} \\
\hline Toxicity & $\begin{array}{l}\mathrm{Nr}^{12} 2^{\top} \\
2,65.02 \mathrm{Mb}\end{array}$ & - & - & $\begin{array}{l}\text { An F344 KO mutant does not show the } \\
\text { increase in NADPH-cytochrome P450 } \\
\text { oxidoreductase protein and activity upon } \\
\text { dexamethasone treatment; on the other hand, } \\
\text { unlike wild-type rats, the SD KO rat fed diet } \\
\text { containing pregnenolone-16alpha-carbonitrile } \\
\text { (a non-genotoxic carcinogen) does not show } \\
\text { increased thyroid gland weight }\end{array}$ & {$[528,529]$} \\
\hline Toxicity (liver) & $\begin{array}{l}\mathrm{Nr}_{13}{ }^{\top} \\
13,89.59 \mathrm{Mb}\end{array}$ & - & - & $\begin{array}{l}\text { Unlike wild-type rats, the SD KO rat fed diet } \\
\text { containing sodium phenobarbital (a non- } \\
\text { genotoxic carcinogen) does not show } \\
\text { increased liver weight, hepatocyte replicative } \\
\text { DNA synthesis and induction of cytochrome } \\
\text { P450 enzymes }\end{array}$ & [529] \\
\hline Vascular function & $\begin{array}{l}M c 4 r^{E N U} \\
18,62.61 \mathrm{Mb}\end{array}$ & Obesity & MC4R18q22 & $\begin{array}{l}\text { The MSH6 KO rat is obese (see above) and } \\
\text { shows bradycardia and increased sympathetic } \\
\text { tone to the vasculature }\end{array}$ & [530] \\
\hline
\end{tabular}


Table 1 Alphabetical list of diseases and related traits with their causative rat genes and the human homologs (Continued)

\begin{tabular}{|c|c|c|c|c|c|}
\hline \multicolumn{2}{|l|}{$\overline{\text { Rat }}$} & \multicolumn{2}{|l|}{ Human } & \multirow[t]{2}{*}{ Comments } & \multirow[t]{2}{*}{ References } \\
\hline Phenotype & $\begin{array}{l}\text { Causative } \\
\text { gene name } \\
\text { Localisation }^{c}\end{array}$ & Phenotype & $\begin{array}{l}\text { Ortholog } \\
\text { gene name } \\
\text { Localisation }^{\mathrm{c}}\end{array}$ & & \\
\hline Vascular function & $\begin{array}{l}\mathrm{Nfe} 2 / 2^{1} \\
3,623.50 \mathrm{Mb}\end{array}$ & - & - & $\begin{array}{l}\text { The SD KO rat shows abnormalities in } \\
\text { endothelium-dependent vasodilation and in } \\
\text { microvessel density (Nfe2/2 also controls } \\
\text { aflatoxin B1 toxicity: see above) }\end{array}$ & [531] \\
\hline $\begin{array}{l}\text { Vascular function } \\
\text { (vasodilation) }\end{array}$ & $\begin{array}{l}\text { Sod3 } 3^{E N U} \\
14,60.96 \mathrm{Mb}\end{array}$ & - & - & $\begin{array}{l}\text { Missense mutation in the SS rat with } \\
\text { deleterious effects on aortic vascular reactivity, } \\
\text { but protective effects in mesenteric arteries; } \\
\text { see also above, Chronic kidney disease }\end{array}$ & [532] \\
\hline $\begin{array}{l}\text { Vascular tone and } \\
\text { nephropathy }\end{array}$ & $\begin{array}{l}\mathrm{Shcl}^{\top} \\
2,188.75 \mathrm{Mb}\end{array}$ & - & - & $\begin{array}{l}\text { The SS rat overexpresses Shcl, a feature linked } \\
\text { to hypertension-induced increased renal } \\
\text { damage; Shc1 KO restores renal microvascular } \\
\text { responses and mitigates glomerular damage } \\
\text { in the SS rat }\end{array}$ & [533] \\
\hline
\end{tabular}

${ }^{a}$ In forward genetic studies, the role of the causative genes is considered proven when complementation, mutation recovery, gene disruption or transgenesis was performed successfully (**); when these tests are lacking, the role of the gene can be either solid (**) (polymorphisms analysed in several contrasting strains, genetic linkage in a cross, or translation to genetic association in the human), or suggestive only (*) (for instance, polymorphism analysed in 2 contrasting strains only). Genes inactivated by ENU-driven target-selected mutagenesis are labeleled as ENU. Targeted mutations (in general, KO rats) are labelled as ${ }^{\top}$

${ }^{\mathrm{b}}$ The human gene is indicated only when it has been implicated in the trait or diseases analysed in the rat

' The gene positions are based on the data available at the NCBI (www.ncbi.nlm.nih.gov/), except those of the Lta-Ncr3 region, derived from [338]; in the case of the rat, the cytogenetic position is indicated only when it was determined by in situ hybridization

${ }^{\mathrm{d}}$ The genomic scan of replicated high- and low-alcohol-drinking lines revealed signature of selection (excessive differentiation in the genomic architecture between lines) in 930 genes [320]; in the above table, only those genes residing in previously identified QTLs are quoted.

${ }^{\mathrm{e}}$ This mutant is in fact a knock-in mutant carrying a human insertion that, unexpectedly, was shown to be spliced out upon transcription, resulting in the generation of a premature stop codon and thus in a loss-of-function allele (except in the olfactory bulb) Abbreviations used in the table:

1) Genes: Abcb1a ATP-binding cassette, sub-family B (MDR/TAP), member 1A (=Mdr1a, Multidrug resistance 1a/P-glycoprotein), Abcc2 ATP-binding cassette, subfamily C (CFTR/MRP), member $2(=$ Moat $=$ Mrp2), Abcc6 ATP binding cassette subfamily C member 6, Abcc8 ATP binding cassette subfamily C member 8 (=Sur1, Sulfonylurea receptor 1), Abcg2 ATP-binding cassette, sub-family G (WHITE), member 2 (Junior blood group) $(=B c r p$, Breast cancer resistance protein), Abcg 5 ATPbinding cassette, sub-family G (WHITE), member 5, ABCG8 ATP-binding cassette, sub-family G (WHITE), member 8, Actr3 ARP3 actin-related protein 3 homolog (yeast), Adamts 16 Disintegrin and metallopeptidase with thrombospondin type 1 motif, 16, Adcyap1r1 Adenylate cyclase activating polypeptide receptor type 1, Add1 Adducing 1 (alpha), Add3 Adducing 3 (gamma), Agtr1a Angiotensin II receptor, type 1a, Adgrl3 Adhesion G protein-coupled receptor L3 (=Lphn3), Adra2a Adrenoceptor alpha 2A, Ahr Aryl hydrocarbon receptor, Angpt/8 Angiopoietin-like 8, Anks6 Ankyrin repeat and sterile alpha motif domain containing 6 (= Pkdr1, Sam (ystin), Ano3 Anoctamin 3, calcium activated chloride channel (=Tmem16c), Apc Adenomatous polyposis coli, Aplec Antigen-presenting lectin-like receptor gene complex (=Dcir3), Apoa4 Apolipoprotein A4, Apoe Apolipoprotein E, Aqp4 Aquaporin 4, Aqp11 Aquaporin 11, Ar Androgen receptor, Arntl Aryl hydrocarbon receptor nuclear translocator-like (=Bmal1), Ar Androgen receptor, Arhgef11 Rho guanine nucleotide exchange factor (GEF) 11, Arsb Arylsulfatase B, Asip Agouti signaling protein, Aspa Aspartoacylase, Atm Ataxia-telangiectasia mutated serine/threonine kinase, Atp7b ATPase, Cu++ transporting, beta polypeptide, Atrn Attractin, Avp Arginin vasopressin, Bace1 Beta-secretase 1, Bckdk Branched chain ketoacid dehydrogenase kinase, Bdnf Brain-derived neurotrophic factor, Bglap Bone gamma-carboxyglutamate protein (=osteocalcin), Brca2 BRCA2, DNA repair associated, Bscl2 BSCL2 lipid droplet biogenesis associated, seipin, CIIta Class II, major histocompatibility complex, transactivator (=Mhc2ta), C3 Complement C3, Cacna1a Calcium channel voltage-dependent subunit alpha 1A, Cacna1c Calcium voltage-gated channel subunit alpha1 C, Cacna1f Calcium voltage-gated channel subunit alpha1 F, Cacna1h Calcium voltage-gated channel subunit alpha1 $\mathrm{H}$, Calcr Calcitonin receptor, Camk2 Calcium/calmodulin-dependent protein kinase II, Camk2n1 Calcium/calmodulin-dependent protein kinase II inhibitor 1, Cav3 Caveolin 3, Cblb Cbl proto-oncogene B, Ccdc39 Coiled-coil containing domain 39, Ccdc85c Coiled-coil containing domain 85C, Cckar Cholecystokinin A receptor, Cd8a Cd8A molecule, Cd36 CD36 molecule, fatty acid translocase, Cd59 Cd59 molecule, Cd247 CD247 molecule (CD3 zeta chain), Cdh13 Cadherin 13, Cdkn1b Cyclin dependent kinase inhibitor 1B, Cfb complement factor B, Cftr Cystic fibrosis transmembrane conductance regulator, Chrm3 Cholinergic receptor, muscarinic 3, Cit Citron rho-interacting serine/threonine kinase, CLEC4A C-type lectin domain family 4, member A (=DCIR), Clec $4 b$ C-type lectin domain family 4, member B, Clec $4 d$ C-type lectin domain family 4 member D $(=M C)$, Clec4e C-type lectin domain family 4 member E (=Mincle), Cntnap2 Contactin associated protein like 2, Cntrob Centrobin, centrosomal BRCA2 interacting protein, $C p$ Ceruloplasmin, Cplx1 Complexin 1, Crb1 Crumbs cell polarity complex component 1, Crebbp CREB binding protein (=Cbp), Crhr2 Corticotropin releasing hormone receptor 2, Cryba1 Crystallin beta A1, Crygd Crystallin gamma D, Csf1 Colony stimulating factor 1, Csf1r Colony stimulating factor 1 receptor, Ctnnd2 Catenin (cadherin-associated protein), delta 2, Ctns Cystinosin, lysosomal cystin transporter, Cyba Cytochrome b-245 alpha chain, Cyp2c11 Cytochrome P450, family 2, subfamily c, polypeptide 11, Cyp2e1 Cytochrome P450, family 2, subfamily e, polypeptide 1, Cyp2j4 Cytochrome P450, family 2, subfamily j, polypeptide 4 (human CYP2J2 ortholog, epoxygenase), Cyp3a1/2 Cytpchrome P450, family 3, subfamily a, polypeptide 1/2, Cyp4f18 Cytochrome P450, family 4, subfamily f, polypeptide 18, Cyp11b1 Cytochrome P450, family 11, subfamily b, polypeptide 1, Cyp17a1 Cytochrome P450 family 17, subfamily a, polypeptide 1, Cyp27b1 Cytochrome P450 family 27 subfamily B member 1, Dao D-amino-acid oxidase, Ddah1 Dimethylarginine dimethylaminohydrolase 1, Defb23/26/42 Defensin beta 23/26/42, Depdc5 DEP domain containing 5, Dhh Desert hedgehog, Dmd Dystrophin, Disc1 Disc1 scaffold protein, Dnd1 DND microRNA-mediated repression inhibitor 1, Dnmt1 DNA methyltransferase 1, Dock8 Dedicator of cytokinesis 8, Dopey1 Dopey family member 1 , Dpp4 Dipeptidyl peptidase 4, Drd1 Dopamine receptor D1, Dsg4 Desmoglein 4, Dusp5 Dual specificity phosphatase 5, Endog endonuclease G, Ephx2 Epoxide hydrolase, Ercc6 ERCC excision repair 6, chromatin remodelling factor (=Csb: Cockayne syndrome B), Esr1 Estrogen receptor 1, Esr2 Estrogen receptor 2, Edaradd EDAR-associated death domain, Ednrb Endothelin receptor type B, F8 Coagulation factor F8, Fah Fumarylacetoacetate hydrolase, Fam129c Family with sequence similarity 129, member C, Fbxo10 F-box protein 10, Fcgr1a Fc fragment of IgG receptor la, Fcgr2a Fc fragment of IgG receptor lla, FCGR3B Fc fragment of IgG receptor IIIb, Fcgr3-rs Fc fragment of IgG receptor III related sequence, Fdft1 Farnesyl diphosphate farnesyltransferase1, Fh fumarate hydratase, Fkbp5 FKBP prolyl isomerase 5, Flcn Folliculin (=Bhd, Birt-Hogg-Dube syndrome homolog), Fmr1 Fragile X mental retardation 1, Folh1 Folate hydrolase 1, Folr1 Folate receptor 1, Foxn1 Forkhead box N1, Frem2 FRAS1 related extracellular matrix protein 2, Frmpd1 FERM and PDZ domain containing 1, Fry Furry homolog (Drosophila), Gdnf Glial cell derived neurotrophic factor, Gh growth hormone, Ghsr Growth hormone secretagogue (ghrelin) receptor, Gimap5 GTPase, IMAP family member 5 (=lan4/ 5), Git2 GIT ArfGAP 2, Gja3 Gap junction protein, alpha 3, Gja8 Gap junction protein, alpha 8 (=Cox50), Gla Galactosidase alpha, Gnal G protein subunit alpha L, Golgb1 Golgin B1, Gper1 G protein-coupled estrogen receptor 1, Gpr183 G protein-coupled receptor 183 (=Ebi2), Grin2a Glutamate ionotropic receptor NMDA type subunit 2A, Grm2 Glutamate metabotropic receptor 2 (=mGlur2), Hcn1 Hyperpolarization activated cyclic nucleotide gated potassium channel 1, Hip1 Huntington- 
interacting protein 1, Hmx $1 \mathrm{H} 6$ family homeobox 1, Hr Hair growth associated, Hsd11b2 Hydroxysteroid 11-beta dehydrogenase 2, Htr7 5-hydroxytryptamine (serotonin) receptor 7, adenylate cyclase-coupled, Igh Immunoglobulin heavy chain locus, Igl Immunoglobulin lambda chain complex, I/1rl2 Interleukin 1 receptor like 2 (=II36r), II2rg Interleukin 2 receptor, gamma, II21r Interleukin 21 receptor, II22ra2 Interleukin 22 receptor, alpha 2, Inpp/1 Inositol polyphosphate phosphatase like 1, Isca 1 Iron-sulfur complex assembly 1, Jund JunD proto-oncogene, AP-1 transcription factor subunit, Kcna1 Potassium voltage-gated channel, shaker-related subfamily, member 1, Kng2 Kininogen 2, Kcnj1 Potassium voltage-gated channel subfamily J member 1 (=Romk), Kcnj10 Potassium voltage-gated channel subfamily J member 10 (=Kir4.1), Kcnj16 Potassium voltage-gated channel subfamily J member 16, Kncq1 Potassium voltage-gated channel, KQT-like subfamily, member 1, Kcnk3 Potassium two pore domain channel subfamily K member 3, Kcnn2 Potassium calcium-activated channel subfamily $\mathrm{N}$ member 2, Kcnn4 Potassium calcium-activated channel subfamily N member 4, Keap1 Kelch like ECH associated protein 1, Kiss1 KISS-1 metastasis-suppressor (kisspeptin), Kit v-kit Hardy-Zuckerman 4 feline sarcoma viral oncogene homolog, Klf5 Kruppel-like factor 5, Krt@ Cytokeratin gene locus (type II), Krt71 Keratin 71, L1 cam L1 cell adhesion molecule, Lamp2 Lysosomal associated membrane protein 2, Ldlr Low density lipoprotein receptor, Lep Leptin, Lepr Leptin receptor, Lgi1 Leucine rich glioma inactivated 1, Lipa Lipase A, lysosomal acid, cholesterol esterase, Lmx1a LIM homeobox transcription factor 1, alpha, Lpar1 Lysophosphatidic acid receptor 1, Lpin 1 Lipin 1 (phosphatidate phosphatase), Lrp5 LDL receptor related protein 5, Lrrk2 Leucine-rich repeat kinase 2, Lss Lanosterol synthase (2,3-oxidosqualenelanosterol cyclase), Lta Lymphotoxin alpha, Ltb Lymphotoxin beta, Lst1 Leukocyte-specific transcript 1, Lyst Lysosomal trafficking regulator, Mas1 MAS1 protooncogen, G-protein-coupled recptor, Mbd2 Methyl CpG binding domain binding protein 2, Mbp Myelin basic protein, Mc4r Melanocortin 4 receptor, Mecp2 MethylCpG binding protein 2, Mertk MER proto-oncogene, tyrosine kinase, Mip Major intrinsic protein of lens fiber, Mir31 Micro RNA 31, Mir146b (5p) Micro RNA 146b, Mir195 Micro RNA 195, Mkx Mohawk homeobox, Mrs2 MRS2 magnesium transporter, Msh6 MutS homolog 6, Mstn Myostatin, Mt-Nd2, Mt-Nd4, Mt-Nd5 Mitochondrial subunits Nd2, Nd4, Nd5 encoding the NAD dehydrogenase (complex I), Muc1 Mucin 1, cellsurface associated, Myh7b Myosin heavy chain 7B, Myo5a:Myosin VA Myo7a Myosin VIIA, Myo9b Myosin IXB, Myo15a Myosin XVA, Myl4 Myosin, light chain 4, Ncf1 Neutrophil cytosolic factor 1 (encodes the 47kilodalton cytosolic subunit of neutrophil NADPH oxidase), Ncf2 Neutrophil cytosolic factor 2 (=p67phox; 7-kilodalton cytosolic subunit of neutrophil NADPH oxidase), NCF4 Neutrophil cytosolic factor 4, $40 \mathrm{kDa}, \mathrm{Ncr} 3$ Natural cytotoxicity triggering receptor 3, Ndufa4 NADH dehydrogenase 1 alpha subcomplex 4, Ndufc2 NADH:ubiquinone oxidoreductase subunit C2, Nek8 NIMA-related kinase 8, Nfe2/2 Nuclear factor, erythroid 2 like 2 (=Nrf2), Ngly1 N-glycanase 1, Nlgn3 Neuroligin3, Nlrp1 NLR family, pyrin domain containing 1, Nox4 NADPH oxidase 4, Nppa Natriuretic peptide A (=Anp), Nppb Natriuretic peptide B (=Bnp), Nppc Natriuretic peptide C $(=C n p)$, Npy Neuropeptide Y, Nr1i2 Nuclear receptor subfamily 1 group I member 2 (=Pxr, Pregnane X receptor), Nr1i3 Nuclear receptor subfamily 1 group I member 3 (=Car, Constitutive androstane receptor), Nr2f2 Nuclear receptor subfamily 2 group F member 2, Nr3c1 Nuclear receptor subfamily 3 group C member 1 (=Gr, Glucocorticoid receptor), Nrg1 Neuregulin 1, Nur4a1 Nuclear receptor subfamily 4 group A member 1 (=Nur77), Oca2 Oculocutaneous albinism II, Ogdh Oxoglutarate dehydrogenase, Ogn Osteoglycin, Oprl1 Opioid related nociceptin receptor 1 (nociceptin/orphanin FQ receptor), P2rx7 Purinergic receptor P2X7, P2ry14 Purinergic receptor P2Y14, Pappa1 Pappalysin 1, Pappa2 Pappalysin 2, Park7 Parkinson protein 7 (=Dj1), Pax6 Paired box 6, Pcdh15 Protocadherin 15, Pclo Piccolo presynaptic cytomatrix protein, Pde3a Phosphodiesterase 3A, Pde6b Phosphodiesterase 6B, Phkg2 Phosphorylase kinase, gamma 2 (testis), Pgls 6phosphogluconolactonase, Phf24 PHD finger protein 24, Pi15 peptidase inhibitor 15, Pink1 Pten induced putative kinase, Pkhd1 Polycystic kidney and hepatic disease 1 (autosomal recessive), Plekha7 Pleckstrin homology domain containing family A member 7, Plekhm1 Pleckstrin homology domain containing, family M (with RUN domain) member 1, Plp1 Proteolipid protein 1, Pmch Pro-melanin-concentrating hormone, Pon1 Paraoxonase 1, Ppp4r3b Protein phosphatase 4 regulatory subunit 3B (=Smek2), Pparg Peroxisome proliferator activated receptor gamma, Prdm14 PR/SET domain 14, Prdx2 Peroxiredoxin 2, Prkdc Protein kinase, DNA-activated, catalytic polypeptide, Prkg2 Protein kinase, cGMP-dependent, type II, Prkn Parkin RBR E3 ubiquitin protein ligase (=Park2), Prlhr Prolactin releasing hormone receptor (=Gpr10), Prss8 Protease, serine, 8, Pten Phosphatase and tensin homolog, Ptprk Protein tyrosine phosphatase, receptor type, K, Rab38 RAB38, member RAS oncogene family, Rag1 Recombination activating gene 1, Rag2 Recombination activating gene 2, Rarres2 Retinoic acid receptor responder 2 (= chemerin), Rbm20 RNA binding motif protein 20, Rffl Ring finger and FYVE like domain containing E3 ubiquitin protein ligase (rififylin), Rffl-Inc1 Rffl-long noncoding RNA, RT1-A RT1 class I, locus $A$, Rin 1 Ras and Rab interactor 1, RT1-Ba RT1 class II, locus Ba, RT1-Bb RT1 class II, locus Bb, Reln Reelin, Ren Renin, Resp18 Regulated endocrine-specific protein 18, Rgma Repulsive guidance molecule BMP co-receptor a, Rnaset2 Ribonuclease T2, Sbf1 SET binding factor 1, Scn1a Sodium channel, voltage-gated, type I, alpha subunit, Scn9a Sodium voltage-gated channel alpha subunit 9 (=Nav 1.7), Serpinc1 Serpin family C member 1 (=antithrombin III), Sh2b3 SH2B adaptor protein 3 (=Lnk), Shank2 SH3 and multiple ankyrin repeat domains 2, Shank3 SH3 and multiple ankyrin repeat domains 3, Shc1 SHC adaptor protein 1, Shroom3 Shroom family member 3, Slc6a3 Solute carrier family 6 member 3 (=DAT, dopamine transporter), Slc6a4 Solute carrier family 6 member 4 (= SERT, serotonin transporter), Slc11a2 Solute carrier family 11 (proton-coupled divalent metal ion transporter), member 2 (=Nramp2), S/c22a18 Solute carrier family 22, member 18, Slc39a12 Solute carrier family 39 member 12 (zinc transporter ZIP12), Slco1b2 Solute carrier organic anion transporter family member 1B2, SLCO1B3 Solute carrier organic anion transporter family member 1B3, Snca Synuclein alpha, Sod3 Superoxide dismutase 3, extracellular, Sorcs1 Sortilin-related VPS10 domain containing receptor 1, Sp6 Sp6 transcription factor, Spata22 Spermatogenesis associated 22, Stim1 Stromal interaction molecule 1, Sv2a synaptic vesicle glycoprotein 2A, Tap2 Transporter 2, ATP-binding cassette, sub-family B (MDR/TAP), Tbc1d1 TBC1 domain family member 1, Tbc1d4 TBC1 domain family member 4 (=As 160), Tbx6 T-box 6, Tfr2 transferrin receptor 2, Themis Thymocyte selection associated, Tg Thyroglobulin, Tlr4 Toll-like receptor 4, Tmem63c Transmembrane protein 63c, Tmem67 Transmembrane protein 67 (=meckelin, Mks3), Tp53 Tumor protein 53, Tph2 Tryptophan hydroxylase 2, Tpcn2 Two pore segment channel 2, Trem2 Triggering receptor expressed on myeloid cells 2, Trpa1 transient receptor potential cation channel, subfamily A, member 1, Trpc4 Transient receptor potential cation channel, subfamily C, member 4, Trpc6 Transient receptor potential cation channel subfamily C member 6, Trpm4 Transient receptor potential cation channel subfamily $\mathrm{M}$ member 4, Trpv1 Transient receptor potential cation channel subfamily $V$ member 1 , Trpv3 Transient receptor potential cation channel, subfamily $\mathrm{V}$, member 3, Trpv4 Transient receptor potential cation channel subfamily $\mathrm{V}$ member 4 , Tsh Thyroid stimulating hormone receptor, Tspo Translocator protein, Tubb4a Tubulin beta 4A class Iva, Tyr Tyrosinase, Uba6 Ubiquitin-like modifier activating enzyme 6, Ubd Ubiquitin D (=Fat10), Ube3a Ubiquitin protein ligase E3A, Ugt1a1 UDP glycosyltransferase 1 family, member A1, Unc5c unc-5 netrin receptor 5 (=Unc5h3), Uox Urate oxidase, uricase, Vav1 Vav1 guanine nucleotide exchange factor, Vdr Vitamin D receptor, Vkorc1 Vitamin K epoxide reductase complex, subunit 1, Wars2 Tryptophanyl tRNA synthetase 2, mitochondrial, Wfs1 Wolframin ER transmembrane glycoprotein, Wwox WW domain-containing oxidase, Zbtb16 Zinc finger and BTB domain containing 16 (=Plzf)

2) Phenotypes and diseases: ADLTE Autosomal dominant lateral temporal lobe epilepsy, ADPKD Autosomal dominant polycystic kidney disease, AKI Acute kidney injury, ALSP Adult-onset leukoencephalopathy with axonal spheroid and pigmented glia, AMD Age-related macular degeneration, ARPKD Autosomal recessive polycystic kidney disease, CAKUT Congenital anomalies of the kidneys and the urinary tract, CDFE Cortical dysplasia-focal epilepsy, CV Cardiovascular, DJS DubinJohnson syndrome, EA2 Episodic ataxia type 2, EAE Experimental autoimmune encephalomyelitis, FHM1 Familial hemiplegic migraine type 1, HNPCC Hereditary non-polyposis colorectal cancer, HPS Hermansky-Pudlak syndrome, HTNB Hypertension with brachydactyly (autosomal dominant), IBD Inflammatory bowel disease, IFAP Ichthyosis follicularis, atrichia, and photophobia, LVH Left ventricular hypertrophy, LVM Left ventricular mass, $P A H$ Pulmonary artery hypertension, $P C H 3$ Pontocerebellar Hypoplasia type 3, PD Parkinson disease, PIA Pristane-induced arthritis, PKHD1 Polycystic kidney and hepatic disease 1, RA Rheumatoid arthritis, RV Right ventricular, SAME Syndrome of apparent mineralocorticoid excess, SCA6 Autosomal dominant spino-cerebellar ataxia 6, T1DM Type 1 diabetes mellitus (Insulin-dependent diabetes mellitus), T2DM Type 2 diabetes mellitus (Non-insulin-dependent diabetes mellitus), VKCFD2 Combined deficiency of vitamin K dependent clotting factors type $2,(X$-)SCID (X-linked) severe combined immunodeficiency 3) Others: ACTH Adrenocorticotropic hormone, CaMK Ca ${ }^{2+} /$ calmodulin-dependent protein kinase, CNS Central nervous system, CRISPR-Cas Clustered regularly interspaced short palindromic repeat, ERE estrogen-responsive-element, ENU N-ethyl-N-nitrosourea, eQTL Expression quantitative trait locus, FHH Fawn-hooded hypertensive, GLP1 Glucagon-like peptide 1, HDL High density lipoproteins, HPA Hypothalamus-pituitary-adrenal, HS Heterogeneous stock, Ig Immunoglobulins, IGF-1 Insulin-like growth factor-1, KO Knockout, LDL Low density lipoprotein, LEW Lewis, LH Lyon hypertensive, LOH Loss of heterozygosity, mTORC1 mTOR complex 1 (MTOR = mechanistic target of rapamycin kinase), MWF Munich Wistar Frömter, QTL Quantitative trait locus, SD Sprague-Dawley, SNP Single nucleotide polymorphism, SHR Spontaneously hypertensive rat, SHRSP Spontaneously hypertensive rat, stroke prone, SHRSR Spontaneously hypertensive rat, stroke resistant, SR Dahl salt-resistant, SS Dahl salt-sensitive, TNF Tumor necrosis factor, UTR Untranslated transcribed region, WT Wild-type, WKY Wistar-Kyoto, ZFN Zinc finger nuclease 
Also, as mentioned above, even when the human gene causing a disease had been identified (without resorting to a rat model), mutated rat strains, in particular $\mathrm{KO}$ strains, were created to analyze the gene function and the disease pathogenesis, and, potentially, to develop new therapies.

This review illustrates the vigor of the rat biomedical research and its value for understanding the etiology of human diseases and for suggesting new therapies.

\section{Abbreviations}

ENU: N-ethyl-N-nitrosourea; GWAS: Genome wide association study; KO: Knockout; NADPH: Nicotinamide adenine dinucleotide phosphate; QTL: Quantitative trait locus; RGD: Rat Genome Database

\section{Acknowledgments}

The author thanks Jennifer R. Smith (RGD) for advice in extracting relevant data from the RGD, in particular using the Disease Portals (https://rgd.mcw. edu/wg/portals/), and the Ministry of Science and Technology, Taiwan, who covers the cost of this publication. The author is an Honorary Research Director of the FNRS (Belgium).

\section{Author's contributions}

CS is the sole author of this paper. The author(s) read and approved the final manuscript.

\section{Authors' information}

I am retired (from the "Université Libre de Bruxelles"); with my coworkers, | contributed, amongst other things, to the development of the rat gene map and the understanding of the genetic basis of susceptibility to rat mammary and uterine cancers [18]

\section{Funding}

This work was not funded.

\section{Availability of data and materials}

Not applicable.

\section{Ethics approval and consent to participate}

Not applicable.

\section{Consent for publication}

Not applicable (a single author).

\section{Competing interests}

The author declares that he has no competing interests.

Received: 27 March 2020 Accepted: 9 July 2020

Published online: 02 August 2020

\section{References}

1. Jacob HJ. The rat: a model used in biomedical research. Methods Mol Biol. 2010;597:1-11.

2. Aitman TJ, Critser JK, Cuppen E, Dominiczak A, Fernandez-Suarez XM, Flint J, et al. Progress and prospects in rat genetics: a community view. Nat Genet. 2008;40(5):516-22.

3. Aitman T, Dhillon P, Geurts AM. A RATional choice for translational research? Dis Model Mech. 2016;9(10):1069-72.

4. James MR, Lindpaintner K. Why map the rat? Trends Genet. 1997;13(5): 171-3.

5. Suckow MA, Hankenson FC, Wilson RP, Foley PL. The laboratory rat. 3rd ed: Elsevier; 2020. p. 1180.

6. Jacob HJ. Functional genomics and rat models. Genome Res. 1999;9(11): 1013-6.

7. Allen PS, Dell'Italia L, Esvelt M, Conte ML, Cadillac JM, Myers DD Jr. Cardiovascular research. In: Suckow MA, Hankenson FC, Wilson RP, Foley PL, editors. The laboratory rat. 3rd ed: Elsevier; 2020. p. 927-5.
8. Hashway SA, Wilding LA. Translational potential of rats in research. In: Suckow MA, Hankenson FC, Wilson RP, Foley PL, editors. The laboratory rat. 3rd ed: Elsevier; 2020. p. 77-88.

9. Szpirer C. Cancer research in rat models. Methods Mol Biol. 2010:597:445-58.

10. Nascimento-Gonçalves E, Faustino-Rocha Al, Seixas F, Ginja M, Colaço B, Ferreira R, et al. Modelling human prostate cancer: rat models. Life Sci. 2018; 203:210-24.

11. Russo J. Significance of rat mammary tumors for human risk assessment. Toxicol Pathol. 2015;43(2):145-70

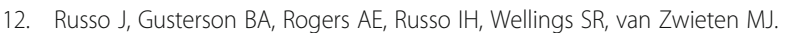
Comparative study of human and rat mammary tumorigenesis. Lab Investig. 1990;62(3):244-78.

13. Sanders J, Samuelson DJ. Significant overlap between human genome-wide association-study nominated breast cancer risk alleles and rat mammary cancer susceptibility loci. Breast Cancer Res. 2014;16(1):R14.

14. Ellenbroek $B$, Youn J. Rodent models in neuroscience research: is it a rat race? Dis Model Mech. 2016;9(10):1079-87.

15. Parker CC, Chen H, Flagel SB, Geurts AM, Richards JB, Robinson TE, et al. Rats are the smart choice: rationale for a renewed focus on rats in behavioral genetics. Neuropharmacology. 2014;76 Pt B:250-8.

16. Carter CS, Richardson A, Huffman DM, Austad S. Bring back the rat! J Gerontol A Biol Sci Med Sci. 2020;75(3):405-15.

17. Homberg JR, Wohr M, Alenina N. Comeback of the rat in biomedical research. ACS Chem Neurosci. 2017;8(5):900-3.

18. Szpirer C, Levan G. Rat gene mapping and genomics. In: Denny P, Kole C, editors. Genome mapping and genomics in laboratory animals. Heidelberg, New York, Dordrecht, London: Springer; 2012. p. 217-56.

19. Wang SJ, SJF L, Zhao Y, Hayman GT, Smith JR, Tutaj M, et al. Integrated curation and data mining for disease and phenotype models at the Rat Genome Database. Database (Oxford). 2019;2019:baz014.

20. Shimoyama M, Smith JR, Bryda E, Kuramoto T, Saba L, Dwinell M. Rat genome and model resources. ILAR J. 2017:58(1):42-58.

21. Mashimo T, Yanagihara K, Tokuda S, Voigt B, Takizawa A, Nakajima R, et al. An ENU-induced mutant archive for gene targeting in rats. Nat Genet. 2008; 40(5):514-5

22. Meek S, Mashimo T, Burdon T. From engineering to editing the rat genome. Mamm Genome. 2017;28(7-8):302-14.

23. Kazuki Y, Kobayashi K, Hirabayashi M, Abe S, Kajitani N, Kazuki K, et al. Humanized UGT2 and CYP3A transchromosomic rats for improved prediction of human drug metabolism. Proc Natl Acad Sci U S A. 2019; 116(8):3072-81.

24. Glazier AM, Nadeau JH, Aitman TJ. Finding genes that underlie complex traits. Science. 2002;298(5602):2345-9.

25. Aitman TJ, Petretto E, Behmoaras J. Genetic mapping and positional cloning. Methods Mol Biol. 2010;597:13-32.

26. Moreno-Moral A, Petretto E. From integrative genomics to systems genetics in the rat to link genotypes to phenotypes. Dis Model Mech. 2016;9(10): 1097-110.

27. Baud A, Flint J. Identifying genes for neurobehavioural traits in rodents: progress and pitfalls. Dis Model Mech. 2017;10(4):373-83.

28. Rat Genome Sequencing and Mapping Consortium, Baud A, Hermsen R, Guryev V, Stridh P, et al. Combined sequence-based and genetic mapping analysis of complex traits in outbred rats. Nat Genet. 2013;45(7):767-75.

29. Pravenec M, Churchill PC, Churchill MC, Viklicky O, Kazdova L, Aitman TJ, et al. Identification of renal $\mathrm{Cd} 36$ as a determinant of blood pressure and risk for hypertension. Nat Genet. 2008;40(8):952-4.

30. Aitman TJ, Glazier AM, Wallace CA, Cooper LD, Norsworthy PJ, Wahid FN, et al. Identification of $\mathrm{Cd} 36$ (Fat) as an insulin-resistance gene causing defective fatty acid and glucose metabolism in hypertensive rats. Nat Genet. 1999;21(1):76-83.

31. Pravenec M, Landa V, Zidek V, Musilova A, Kren V, Kazdova L, et al. Transgenic rescue of defective $\mathrm{Cd} 36$ ameliorates insulin resistance in spontaneously hypertensive rats. Nat Genet. 2001;27(2):156-8.

32. Corpeleijn E, van der Kallen CJ, Kruijshoop M, Magagnin MG, de Bruin TW, Feskens EJ, et al. Direct association of a promoter polymorphism in the CD36/FAT fatty acid transporter gene with type 2 diabetes mellitus and insulin resistance. Diabet Med. 2006;23(8):907-11.

33. Cheng X, Waghulde H, Mell B, Morgan EE, Pruett-Miller SM, Joe B. Positional cloning of quantitative trait nucleotides for blood pressure and cardiac QTinterval by targeted CRISPR/Cas9 editing of a novel long non-coding RNA. PLoS Genet. 2017;13(8):e1006961. 
34. Newton-Cheh C, Eijgelsheim M, Rice KM, de Bakker PI, Yin X, Estrada K, et al. Common variants at ten loci influence QT interval duration in the QTGEN study. Nat Genet. 2009:41(4):399-406.

35. Rubattu S, Stanzione R, Volpe M. Mitochondrial dysfunction contributes to hypertensive target organ damage: lessons from an animal model of human disease. Oxidative Med Cell Longev. 2016;2016:1067801.

36. Rubattu S, Di Castro S, Schulz H, Geurts AM, Cotugno M, Bianchi F, et al. Ndufc2 gene inhibition is associated with mitochondrial dysfunction and increased stroke susceptibility in an animal model of complex human disease. J Am Heart Assoc. 2016;5(2):e002701.

37. Visscher PM, Wray NR, Zhang Q, Sklar P, McCarthy MI, Brown MA, et al. 10 years of GWAS discovery: biology, function, and translation. Am J Hum Genet. 2017;101(1):5-22.

38. Auer PL, Stitziel NO. Genetic association studies in cardiovascular diseases: do we have enough power? Trends Cardiovasc Med. 2017;27(6):397-404.

39. Flister MJ, Tsaih SW, O'Meara CC, Endres B, Hoffman MJ, Geurts AM, et al. Identifying multiple causative genes at a single GWAS locus. Genome Res. 2013;23(12):1996-2002.

40. Peng W, Li M, Li H, Tang K, Zhuang J, Zhang J, et al. Dysfunction of myosin light-chain 4 (MYL4) leads to heritable atrial cardiomyopathy with electrical, contractile, and structural components: evidence from geneticallyengineered rats. J Am Heart Assoc. 2017;6(11):e007030.

41. Smith M. DNA sequence analysis in clinical medicine, proceeding cautiously. Front Mol Biosci. 2017:4:24

42. Harony-Nicolas H, Kay M, du Hoffmann J, Klein ME, Bozdagi-Gunal O, Riad $M$, et al. Oxytocin improves behavioral and electrophysiological deficits in a novel Shank3-deficient rat. Elife. 2017;6:e18904.

43. Olsson LM, Lindqvist AK, Kallberg H, Padyukov L, Burkhardt H, Alfredsson L, et al. A case-control study of rheumatoid arthritis identifies an associated single nucleotide polymorphism in the NCF4 gene, supporting a role for the NADPHoxidase complex in autoimmunity. Arthritis Res Ther. 2007;9(5):R98.

44. Gelderman KA, Hultqvist M, Olsson LM, Bauer K, Pizzolla A, Olofsson P, et al. Rheumatoid arthritis: the role of reactive oxygen species in disease development and therapeutic strategies. Antioxid Redox Signal. 2007;9(10): 1541-67.

45. Hultqvist M, Olofsson P, Gelderman KA, Holmberg J, Holmdahl R. A new arthritis therapy with oxidative burst inducers. PLoS Med. 2006;3(9):e348.

46. Ercu M, Marko L, Schachterle C, Tsvetkov D, Cui Y, Maghsodi S, et al. Phosphodiesterase 3A and arterial hypertension. Circulation. 2020;142(2): 133-49.

47. Puissant MM, Muere $C$, Levchenko V, Manis AD, Martino P, Forster HV, et al. Genetic mutation of Kcnj16 identifies Kir5.1-containing channels as key regulators of acute and chronic pH homeostasis. FASEB J. 2019;33(4):5067-75.

48. St Laurent R, Helm SR, Glenn MJ. Reduced cocaine-seeking behavior in heterozygous BDNF knockout rats. Neurosci Lett. 2013;544:94-9.

49. King CP, Militello L, Hart A, St Pierre CL, Leung E, Versaggi $C L$, et al. Cdh13 and AdipoQ gene knockout alter instrumental and Pavlovian drug conditioning. Genes Brain Behav. 2017;16(7):686-98.

50. Gao JT, Jordan CJ, Bi GH, He Y, Yang HJ, Gardner EL, et al. Deletion of the type 2 metabotropic glutamate receptor increases heroin abuse vulnerability in transgenic rats. Neuropsychopharmacology. 2018;43(13): 2615-26.

51. Yang HJ, Zhang HY, Bi GH, He Y, Gao JT, Xi ZX. Deletion of type 2 metabotropic glutamate receptor decreases sensitivity to cocaine reward in rats. Cell Rep. 2017;20(2):319-32.

52. Yamamoto T, Izumi-Yamamoto K, lizuka $Y$, Shirota M, Nagase M, Fujita T, et al. A novel link between Slc22a18 and fat accumulation revealed by a mutation in the spontaneously hypertensive rat. Biochem Biophys Res Commun. 2013;440(4):521-6.

53. Dang R, Sasaki N, Nishino T, Nakanishi M, Torigoe D, Agui T. Lymphopenia in Ednrb-deficient rat was strongly modified by genetic background. Biomed Res. 2012;33(4):249-53.

54. Gariepy CE, Cass DT, Yanagisawa M. Null mutation of endothelin receptor type B gene in spotting lethal rats causes aganglionic megacolon and white coat color. Proc Natl Acad Sci U S A. 1996;93(2):867-72.

55. Kunieda T, Kumagai T, Tsuji T, Ozaki T, Karaki H, Ikadai H. A mutation in endothelin-B receptor gene causes myenteric aganglionosis and coat color spotting in rats. DNA Res. 1996:3(2):101-5.

56. Dang R, Torigoe D, Sasaki N, Agui T. QTL analysis identifies a modifier locus of aganglionosis in the rat model of Hirschsprung disease carrying Ednrb(sl) mutations. PLoS One. 2011;6(11):e27902.
57. Huang J, Dang R, Torigoe D, Li A, Lei C, Sasaki N, et al. Genetic variation in the GDNF promoter affects its expression and modifies the severity of Hirschsprung's disease (HSCR) in rats carrying Ednrb(sl) mutations. Gene. 2016:575(1):144-8.

58. Wang J, Dang R, Miyasaka Y, Hattori K, Torigoe D, Okamura T, et al. Null mutation of the endothelin receptor type $B$ gene causes embryonic death in the GK rat. PLoS One. 2019;14(6):e0217132.

59. Ceccherini I, Zhang AL, Matera I, Yang G, Devoto M, Romeo G, et al. Interstitial deletion of the endothelin-B receptor gene in the spotting lethal (sl) rat. Hum Mol Genet. 1995;4(11):2089-96.

60. Pridans C, Raper A, Davis GM, Alves J, Sauter KA, Lefevre L, et al. Pleiotropic impacts of macrophage and microglial deficiency on development in rats with targeted mutation of the Csf1r locus. J Immunol. 2018;201(9):2683-99.

61. Muto T, Miyoshi K, Horiguchi T, Hagita H, Noma T. Novel genetic linkage of rat Sp6 mutation to Amelogenesis imperfecta. Orphanet J Rare Dis. 2012;7:34.

62. Esumi H, Takahashi Y, Sato S, Nagase S, Sugimura T. A seven-base-pair deletion in an intron of the albumin gene of analbuminemic rats. Proc Natl Acad Sci U S A. 1983;80(1):95-9.

63. Tsujimura T, Hirota S, Nomura S, Niwa Y, Yamazaki M, Tono T, et al. Characterization of Ws mutant allele of rats: a 12-base deletion in tyrosine kinase domain of c-kit gene. Blood. 1991;78(8):1942-6.

64. Fleming MD, Romano MA, Su MA, Garrick LM, Garrick MD, Andrews NC. Nramp2 is mutated in the anemic Belgrade (b) rat: evidence of a role for Nramp2 in endosomal iron transport. Proc Natl Acad Sci U S A. 1998;95(3): 1148-53.

65. Berg EL, Pride MC, Petkova SP, Lee RD, Copping NA, Shen Y, et al. Translational outcomes in a full gene deletion of ubiquitin protein ligase E3A rat model of Angelman syndrome. Transl Psychiatry. 2020;10(1):39.

66. Tokuda S, Kuramoto T, Tanaka K, Kaneko S, Takeuchi IK, Sasa M, et al. The ataxic groggy rat has a missense mutation in the P/Q-type voltage-gated $\mathrm{Ca} 2+$ channel alpha1A subunit gene and exhibits absence seizures. Brain Res. 2007:1133(1):168-77.

67. Quek H, Luff J, Cheung K, Kozlov S, Gatei M, Lee CS, et al. A rat model of ataxia-telangiectasia: evidence for a neurodegenerative phenotype. Hum Mol Genet. 2017;26(1):109-23.

68. Quek H, Luff J, Cheung K, Kozlov S, Gatei M, Lee CS, et al. Rats with a missense mutation in Atm display neuroinflammation and neurodegeneration subsequent to accumulation of cytosolic DNA following unrepaired DNA damage. J Leukoc Biol. 2017;101(4):927-47.

69. Scott KE, Schormans AL, Pacoli KY, De Oliveira C, Allman BL, Schmid S. Altered auditory processing, filtering, and reactivity in the Cntnap2 knockout rat model for neurodevelopmental disorders. J Neurosci. 2018;38(40): 8588-604.

70. Hamilton SM, Green JR, Veeraragavan S, Yuva L, McCoy A, Wu Y, et al. Fmr1 and Nlgn3 knockout rats: novel tools for investigating autism spectrum disorders. Behav Neurosci. 2014;128(2):103-9.

71. Thomas AM, Schwartz MD, Saxe MD, Kilduff TS. Sleep/wake physiology and quantitative electroencephalogram analysis of the Neuroligin-3 knockout rat model of autism spectrum disorder. Sleep. 2017:40(10):Zsx138.

72. Modi ME, Brooks JM, Guilmette ER, Beyna M, Graf R, Reim D, et al. Hyperactivity and hypermotivation associated with increased striatal mGluR1 signaling in a Shank2 Rat model of autism. Front Mol Neurosci. 2018:11:107.

73. Kuwamura M, Muraguchi T, Matsui T, Ueno M, Takenaka S, Yamate J, et al. Mutation at the Lmx1a locus provokes aberrant brain development in the rat. Brain Res Dev Brain Res. 2005;155(2):99-106.

74. Cotroneo MS, Haag JD, Zan Y, Lopez CC, Thuwajit P, Petukhova GV, et al. Characterizing a rat Brca2 knockout model. Oncogene. 2007;26(11):1626-35.

75. van Boxtel R, Toonen PW, van Roekel HS, Verheul M, Smits BM, Korving J, et al. Lack of DNA mismatch repair protein MSH6 in the rat results in hereditary non-polyposis colorectal cancer-like tumorigenesis. Carcinogenesis. 2008:29(6):1290-7.

76. Yan HX, Wu HP, Ashton C, Tong C, Ying QL. Rats deficient for p53 are susceptible to spontaneous and carcinogen-induced tumorigenesis. Carcinogenesis. 2012;33(10):2001-5

77. van Boxtel R, Kuiper RV, Toonen PW, van Heesch S, Hermsen R, de Bruin A, et al. Homozygous and heterozygous p53 knockout rats develop metastasizing sarcomas with high frequency. Am J Pathol. 2011;179(4):1616-22.

78. Hansen SA, Hart ML, Busi S, Parker T, Goerndt A, Jones K, et al. Fischer-344 Tp53-knockout rats exhibit a high rate of bone and brain neoplasia with frequent metastasis. Dis Model Mech. 2016;9(10):1139-46. 
79. McCoy A, Besch-Williford CL, Franklin CL, Weinstein EJ, Cui X. Creation and preliminary characterization of a Tp53 knockout rat. Dis Model Mech. 2013; 6(1):269-78

80. Yoshimi K, Tanaka T, Takizawa A, Kato M, Hirabayashi M, Mashimo T, et al. Enhanced colitis-associated colon carcinogenesis in a novel Apc mutant rat. Cancer Sci. 2009;100(11):2022-7.

81. Amos-Landgraf JM, Kwong LN, Kendziorski CM, Reichelderfer M, Torrealba J, Weichert J, et al. A target-selected Apc-mutant rat kindred enhances the modeling of familial human colon cancer. Proc Natl Acad Sci U S A. 2007; 104(10):4036-41.

82. Irving AA, Yoshimi K, Hart ML, Parker T, Clipson L, Ford MR, et al. The utility of Apc-mutant rats in modeling human colon cancer. Dis Model Mech. 2014;7(11):1215-25.

83. Ding L, Shunkwiler LB, Harper NW, Zhao Y, Hinohara K, Huh SJ, et al. Deletion of $\mathrm{Cdkn} 1 \mathrm{~b}$ in $\mathrm{ACl}$ rats leads to increased proliferation and pregnancy-associated changes in the mammary gland due to perturbed systemic endocrine environment. PLoS Genet. 2019;15(3):e1008002.

84. Pellegata NS, Quintanilla-Martinez L, Siggelkow H, Samson E, Bink K, Hofler $\mathrm{H}$, et al. Germ-line mutations in p27Kip1 cause a multiple endocrine neoplasia syndrome in rats and humans. Proc Natl Acad Sci U S A. 2006; 103(42):15558-63.

85. Okimoto K, Sakurai J, Kobayashi T, Mitani H, Hirayama Y, Nickerson ML, et al. A germ-line insertion in the Birt-Hogg-Dube (BHD) gene gives rise to the Nihon rat model of inherited renal cancer. Proc Natl Acad Sci U S A. 2004; 101(7):2023-7.

86. Yeung RS, Xiao GH, Jin F, Lee WC, Testa JR, Knudson AG. Predisposition to renal carcinoma in the Eker rat is determined by germ-line mutation of the tuberous sclerosis 2 (TSC2) gene. Proc Natl Acad Sci U S A. 1994;91(24): 11413-6.

87. Flister MJ, Hoffman MJ, Lemke A, Prisco SZ, Rudemiller N, O'Meara CC, et al. $\mathrm{SH} 2 \mathrm{~B} 3$ is a genetic determinant of cardiac inflammation and fibrosis. Circ Cardiovasc Genet. 2015;8(2):294-304.

88. Luo C, Xie X, Feng X, Lei B, Fang C, Li Y, et al. Deficiency of Interleukin-36 receptor protected cardiomyocytes from ischemia-reperfusion injury in cardiopulmonary bypass. Med Sci Monit. 2020;26:e918933.

89. Zhou Q, Peng X, Liu X, Chen L, Xiong Q, Shen Y, et al. FAT10 attenuates hypoxia-induced cardiomyocyte apoptosis by stabilizing caveolin-3. J Mol Cell Cardiol. 2018;116:115-24

90. Wu T, Ma YW, Zhang X, Dong W, Gao S, Wang JZ, et al. Myocardial tissuespecific Dnmt1 knockout in rats protects against pathological injury induced by Adriamycin. Lab Invest. 2020;100(7):974-85.

91. Chen P, Li Z, Nie J, Wang H, Yu B, Wen Z, et al. MYH7B variants cause hypertrophic cardiomyopathy by activating the CaMK-signaling pathway. Sci China Life Sci. 2020; https://doi.org/10.1007/s11427-019-1627-y.

92. Guo W, Pleitner JM, Saupe KW, Greaser ML. Pathophysiological defects and transcriptional profiling in the RBM20-/- rat model. PLoS One. 2013;8(12): e84281.

93. Zigler JS Jr, Zhang C, Grebe R, Sehrawat G, Hackler L Jr, Adhya S, et al. Mutation in the betaA3/A1-crystallin gene impairs phagosome degradation in the retinal pigmented epithelium of the rat. J Cell Sci. 2011;124(Pt 4):52331.

94. Sinha D, Klise A, Sergeev $Y$, Hose S, Bhutto IA, Hackler L Jr, et al. betaA3/A1crystallin in astroglial cells regulates retinal vascular remodeling during development. Mol Cell Neurosci. 2008;37(1):85-95.

95. Johnson AC, Lee JW, Harmon AC, Morris Z, Wang X, Fratkin J, et al. A mutation in the start codon of gamma-crystallin $D$ leads to nuclear cataracts in the dahl SS/Jr-Ctr strain. Mamm Genome. 2013;24(3-4):95-104

96. Yoshida M, Harada Y, Kaidzu S, Ohira A, Masuda J, Nabika T. New genetic model rat for congenital cataracts due to a connexin 46 (Gja3 ) mutation. Pathol Int. 2005;55(11):732-7.

97. Liska F, Chylikova B, Martinek J, Kren V. Microphthalmia and cataract in rats with a novel point mutation in connexin 50 - L7Q. Mol Vis. 2008;14:823-8.

98. Yamashita S, Furumoto K, Nobukiyo A, Kamohara M, Ushijima T, Furukawa T. Mapping of A gene responsible for cataract formation and its modifier in the UPL rat. Invest Ophthalmol Vis Sci. 2002;43(10):3153-9.

99. Mori M, Li G, Abe I, Nakayama J, Guo Z, Sawashita J, et al. Lanosterol synthase mutations cause cholesterol deficiency-associated cataracts in the Shumiya cataract rat. J Clin Invest. 2006;116(2):395-404.

100. Zhao L, Chen XJ, Zhu J, Xi YB, Yang X, Hu LD, et al. Lanosterol reverses protein aggregation in cataracts. Nature. 2015:523(7562):607-11.
101. Watanabe K, Wada K, Ohashi T, Okubo S, Takekuma K, Hashizume R, et al. A 5-bp insertion in Mip causes recessive congenital cataract in KFRS4/Kyo rats. PLoS One. 2012;7(11):e50737.

102. Mori M, Nishikawa T, Higuchi K, Nishimura M. Deletion in the beige gene of the beige rat owing to recombination between LINE1s. Mamm Genome. 1999:10(7):692-5.

103. Kuramoto T, Kuwamura M, Serikawa T. Rat neurological mutations cerebellar vermis defect and hobble are caused by mutations in the netrin-1 receptor gene Unc5h3. Brain Res Mol Brain Res. 2004;122(2):103-8.

104. Mashimo T, Kaneko T, Sakuma T, Kobayashi J, Kunihiro Y, Voigt B, et al. Efficient gene targeting by TAL effector nucleases coinjected with exonucleases in zygotes. Sci Rep. 2013;3:1253.

105. Blaszczyk WM, Arning L, Hoffmann KP, Epplen JT. A Tyrosinase missense mutation causes albinism in the Wistar rat. Pigment Cell Res. 2005;18(2): $144-5$.

106. Kuramoto T, Yokoe M, Yagasaki K, Kawaguchi T, Kumafuji K, Serikawa T. Genetic analyses of fancy rat-derived mutations. Exp Anim. 2010;59(2):14755.

107. Yoshimi K, Kaneko T, Voigt B, Mashimo T. Allele-specific genome editing and correction of disease-associated phenotypes in rats using the CRISPRCas platform. Nat Commun. 2014;5:4240.

108. Kuramoto T, Nomoto T, Sugimura T, Ushijima T. Cloning of the rat agouti gene and identification of the rat nonagouti mutation. Mamm Genome. 2001;12(6):469-71

109. Yoshihara M, Sato T, Saito D, Ohara O, Kuramoto T, Suyama M. A deletion in the intergenic region upstream of Ednrb causes head spot in the rat strain KFRS4/Kyo. BMC Genet. 2017;18(1):29.

110. Kuramoto T, Nakanishi S, Ochiai M, Nakagama H, Voigt B, Serikawa T. Origins of albino and hooded rats: implications from molecular genetic analysis across modern laboratory rat strains. PLoS One. 2012;7(8):e43059.

111. Xu Y, Wu Z, Liu L, Liu J, Wang Y. Rat model of Cockayne syndrome neurological disease. Cell Rep. 2019;29(4):800-9.e5.

112. Gu Y, Wang L, Zhou J, Guo Q, Liu N, Ding Z, et al. A naturally-occurring mutation in Cacna1f in a rat model of congenital stationary night blindness. Mol Vis. 2008;14:20-8.

113. Yokoi N, Namae M, Wang HY, Kojima K, Fuse M, Yasuda K, et al. Rat neurological disease creeping is caused by a mutation in the reelin gene. Brain Res Mol Brain Res. 2003;112(1-2):1-7.

114. Tuggle KL, Birket SE, Cui X, Hong J, Warren J, Reid L, et al. Characterization of defects in ion transport and tissue development in cystic fibrosis transmembrane conductance regulator (CFTR)-knockout rats. PLoS One. 2014:9(3):e91253.

115. Dreano E, Bacchetta M, Simonin J, Galmiche L, Usal C, Slimani L, et al. Characterization of two rat models of cystic fibrosis-KO and F508del CFTRgenerated by Crispr-Cas9. Animal Model Exp Med. 2019;2(4):297-311.

116. Sinkevicius KW, Morrison TR, Kulkarni P, Caffrey Cagliostro MK, Iriah S, Malmberg S, et al. RNaseT2 knockout rats exhibit hippocampal neuropathology and deficits in memory. Dis Model Mech. 2018;11(6): dmm032631.

117. Shimizu Y, Yanobu-Takanashi R, Nakano K, Hamase K, Shimizu T, Okamura T. A deletion in the Ctns gene causes renal tubular dysfunction and cystine accumulation in LEA/Tohm rats. Mamm Genome. 2019;30(1-2):23-33.

118. Ma S, Zhang M, Zhang S, Wang J, Zhou X, Guo G, et al. Characterisation of Lamp2-deficient rats for potential new animal model of Danon disease. Sci Rep. 2018:8(1):6932.

119. Shimizu Y, Ishii C, Yanobu-Takanashi R, Nakano K, Imaike A, Mita M, et al. dAmino acid oxidase deficiency is caused by a large deletion in the Dao gene in LEA rats. Biochim Biophys Acta Proteins Proteom. 1868;2020(9): 140463.

120. Gohma H, Kuramoto T, Kuwamura M, Okajima R, Tanimoto N, Yamasaki K, et al. WTC deafness Kyoto (dfk): a rat model for extensive investigations of Kcnq1 functions. Physiol Genomics. 2006;24(3):198-206.

121. Smits BM, Peters TA, Mul JD, Croes HJ, Fransen JA, Beynon AJ, et al. Identification of a rat model for usher syndrome type $1 \mathrm{~B}$ by $\mathrm{N}$-ethyl-Nnitrosourea mutagenesis-driven forward genetics. Genetics. 2005;170(4): 1887-96.

122. Naoi K, Kuramoto T, Kuwamura Y, Gohma H, Kuwamura M, Serikawa T. Characterization of the Kyoto circling $(\mathrm{KCl})$ rat carrying a spontaneous nonsense mutation in the protocadherin 15 (Pcdh15) gene. Exp Anim. 2009; 58(1):1-10. 
123. Held N, Smits BM, Gockeln R, Schubert S, Nave H, Northrup E, et al. A mutation in Myo15 leads to Usher-like symptoms in LEW/Ztm-ci2 rats. PLoS One. 2011;6(3):e15669.

124. Nishitani A, Tanaka M, Shimizu S, Kunisawa N, Yokoe M, Yoshida Y, et al. Involvement of aspartoacylase in tremor expression in rats. Exp Anim. 2016; 65(3):293-301

125. O'Connor LT, Goetz BD, Kwiecien JM, Delaney KH, Fletch AL, Duncan ID. Insertion of a retrotransposon in Mbp disrupts mRNA splicing and myelination in a new mutant rat. J Neurosci. 1999;19(9):3404-13.

126. Kuramoto T, Kuwamura M, Tokuda S, Izawa T, Nakane $Y$, Kitada K, et al. A mutation in the gene encoding mitochondrial Mg(2)+ channel MRS2 results in demyelination in the rat. PLOS Genet. 2011;7(1):e1001262.

127. Boison D, Stoffel W. Myelin-deficient rat: a point mutation in exon III (A----C, Thr75----Pro) of the myelin proteolipid protein causes dysmyelination and oligodendrocyte death. EMBO J. 1989;8(11):3295-302.

128. Duncan ID, Bugiani M, Radcliff AB, Moran JJ, Lopez-Anido C, Duong P, et al. A mutation in the Tubb4a gene leads to microtubule accumulation with hypomyelination and demyelination. Ann Neurol. 2017:81(5):690-702.

129. Geddes BJ, Harding TC, Lightman SL, Uney JB. Long-term gene therapy in the CNS: reversal of hypothalamic diabetes insipidus in the Brattleboro rat by using an adenovirus expressing arginine vasopressin. Nat Med. 1997; 3(12):1402-4.

130. Schmale H, Richter D. Single base deletion in the vasopressin gene is the cause of diabetes insipidus in Brattleboro rats. Nature. 1984:308:705-9.

131. Mamenko M, Dhande I, Tomilin V, Zaika O, Boukelmoune N, Zhu Y, et al. Defective store-operated calcium entry causes partial nephrogenic diabetes insipidus. J Am Soc Nephrol. 2016;27(7):2035-48.

132. Takagishi $Y$, Murata $Y$. Myosin Va mutation in rats is an animal model for the human hereditary neurological disease, Griscelli syndrome type 1. Ann N Y Acad Sci. 2006;1086:66-80.

133. Landrock KK, Sullivan P, Martini-Stoica H, Goldstein DS, Graham BH, Yamamoto S, et al. Pleiotropic neuropathological and biochemical alterations associated with Myo5a mutation in a rat model. Brain Res. 1679; 2018:155-70.

134. Larcher T, Lafoux A, Tesson L, Remy S, Thepenier V, Francois V, et al. Characterization of dystrophin deficient rats: a new model for Duchenne muscular dystrophy. PLoS One. 2014;9(10):e110371.

135. Nakamura K, Fujii W, Tsuboi M, Tanihata J, Teramoto N, Takeuchi S, et al. Generation of muscular dystrophy model rats with a CRISPR/Cas system. Sci Rep. 2014;4:5635

136. Clifford PS, Rodriguez J, Schul D, Hughes S, Kniffin T, Hart N, et al. Attenuation of cocaine-induced locomotor sensitization in rats sustaining genetic or pharmacologic antagonism of ghrelin receptors. Addict Biol. 2012;17(6):956-63.

137. Chu X, Zhang Z, Yabut J, Horwitz S, Levorse J, Li XQ, et al. Characterization of multidrug resistance 1a/P-glycoprotein knockout rats generated by zinc finger nucleases. Mol Pharmacol. 2012;81(2):220-7.

138. Zamek-Gliszczynski MJ, Bedwell DW, Bao JQ, Higgins JW. Characterization of SAGE Mdr1a (P-gp), Bcrp, and Mrp2 knockout rats using loperamide, paclitaxel, sulfasalazine, and carboxydichlorofluorescein pharmacokinetics. Drug Metab Dispos. 2012;40(9):1825-33.

139. Fuchs H, Kishimoto W, Gansser D, Tanswell P, Ishiguro N. Brain penetration of WEB 2086 (Apafant) and dantrolene in Mdr1a (P-glycoprotein) and Bcrp knockout rats. Drug Metab Dispos. 2014:42(10):1761-5.

140. Liu X, Cheong J, Ding X, Deshmukh G. Use of cassette dosing approach to examine the effects of P-glycoprotein on the brain and cerebrospinal fluid concentrations in wild-type and P-glycoprotein knockout rats. Drug Metab Dispos. 2014;42(4):482-91.

141. Wei Y, Yang L, Zhang X, Sui D, Wang C, Wang K, et al. Generation and characterization of a CYP2C11-null rat model by using the CRISPR/Cas9 method. Drug Metab Dispos. 2018:46(5):525-31.

142. Wang RL, Xia QQ, Baerson SR, Ren Y, Wang J, Su YJ, et al. A novel cytochrome P450 CYP6AB14 gene in Spodoptera litura (Lepidoptera: Noctuidae) and its potential role in plant allelochemical detoxification. J Insect Physiol. 2015;75:54-62.

143. Lu J, Shao Y, Qin X, Liu D, Chen A, Li D, et al. CRISPR knockout rat cytochrome P450 3A1/2 model for advancing drug metabolism and pharmacokinetics research. Sci Rep. 2017;7:42922.

144. Takeuchi T, Suzuki H, Sakurai S, Nogami H, Okuma S, Ishikawa H. Molecular mechanism of growth hormone $(\mathrm{GH})$ deficiency in the spontaneous dwarf rat: detection of abnormal splicing of $\mathrm{GH}$ messenger ribonucleic acid by the polymerase chain reaction. Endocrinology. 1990;126(1):31-8.

145. Chikuda H, Kugimiya F, Hoshi K, Ikeda T, Ogasawara T, Shimoaka T, et al. Cyclic GMP-dependent protein kinase II is a molecular switch from proliferation to hypertrophic differentiation of chondrocytes. Genes Dev. 2004;18(19):2418-29.

146. Bonnet C, Andrieux J, Beri-Dexheimer M, Leheup B, Boute O, Manouvrier S, et al. Microdeletion at chromosome 4q21 defines a new emerging syndrome with marked growth restriction, mental retardation and absent or severely delayed speech. J Med Genet. 2010;47(6):377-84.

147. Tsuchida A, Yokoi N, Namae M, Fuse M, Masuyama T, Sasaki M, et al. Phenotypic characterization of the Komeda miniature rat Ishikawa, an animal model of dwarfism caused by a mutation in Prkg2. Comp Med. 2008;58(6):560-7.

148. Hishinuma A, Furudate S, Oh-Ishi M, Nagakubo N, Namatame T, leiri T. A novel missense mutation (G2320R) in thyroglobulin causes hypothyroidism in rdw rats. Endocrinology. 2000;141(11):4050-5.

149. Furudate S, Ono M, Shibayama K, Ohyama Y, Kuwada M, Kimura T, et al. Rescue from dwarfism by thyroid function compensation in rdw rats. Exp Anim. 2005;54(5):455-60

150. Yu-Taeger L, Ott T, Bonsi $P$, Tomczak C, Wassouf Z, Martella G, et al. Impaired dopamine- and adenosine-mediated signaling and plasticity in a novel rodent model for DYT25 dystonia. Neurobiol Dis. 2020;134:104634.

151. Quina LA, Kuramoto T, Luquetti DV, Cox TC, Serikawa T, Turner EE. Deletion of a conserved regulatory element required for $\mathrm{Hmx} 1$ expression in craniofacial mesenchyme in the dumbo rat: a newly identified cause of congenital ear malformation. Dis Model Mech. 2012;5(6):812-22.

152. Mori M, Li G, Hashimoto M, Nishio A, Tomozawa H, Suzuki N, et al. Pivotal advance: eosinophilia in the MES rat strain is caused by a loss-of-function mutation in the gene for cytochrome b(-245), alpha polypeptide (Cyba). J Leukoc Biol. 2009;86(3):473-8.

153. Sarkisian MR, Li W, Di Cunto F, D'Mello SR, LoTurco JJ. Citron-kinase, a protein essential to cytokinesis in neuronal progenitors, is deleted in the flathead mutant rat. J Neurosci. 2002;22(8):RC217.

154. Sarkisian MR, Rattan S, D'Mello SR, LoTurco JJ. Characterization of seizures in the flathead rat: a new genetic model of epilepsy in early postnatal development. Epilepsia. 1999;40(4):394-400.

155. Thomas AM, Schwartz MD, Saxe MD, Kilduff TS. Cntnap2 knockout rats and mice exhibit epileptiform activity and abnormal sleep-wake physiology. Sleep. 2017:40(1):Zsw026

156. Ishida S, Sakamoto Y, Nishio T, Baulac S, Kuwamura M, Ohno Y, et al. Kcna1mutant rats dominantly display myokymia, neuromyotonia and spontaneous epileptic seizures. Brain Res. 2012;1435:154-66.

157. Baulac S, Ishida S, Mashimo T, Boillot M, Fumoto N, Kuwamura M, et al. A rat model for LGI1-related epilepsies. Hum Mol Genet. 2012;21(16):3546-57.

158. Kinboshi M, Shimizu S, Mashimo T, Serikawa T, Ito H, Ikeda A, et al. Downregulation of astrocytic Kir4.1 channels during the audiogenic epileptogenesis in Leucine-Rich Glioma-Inactivated 1 (Lgi1) mutant rats. Int Mol Sci. 2019;20(5):1013

159. Mashimo T, Ohmori I, Ouchida M, Ohno Y, Tsurumi T, Miki T, et al. A missense mutation of the gene encoding voltage-dependent sodium channel (Nav1.1) confers susceptibility to febrile seizures in rats. J Neurosci. 2010:30(16):5744-53.

160. Tokudome K, Okumura T, Shimizu S, Mashimo T, Takizawa A, Serikawa T, et al. Synaptic vesicle glycoprotein 2A (SV2A) regulates kindling epileptogenesis via GABAergic neurotransmission. Sci Rep. 2016;6:27420.

161. Suzuki H, Katayama K, Takenaka M, Amakasu K, Saito K, Suzuki K. A spontaneous mutation of the Wwox gene and audiogenic seizures in rats with lethal dwarfism and epilepsy. Genes Brain Behav. 2009;8(7):650-60.

162. Miller JJ, Aoki K, Moehring F, Murphy CA, O'Hara CL, Tiemeyer M, et al. Neuropathic pain in a Fabry disease rat model. JCI Insight. 2018;3(6):e99171.

163. Bulbul M, Babygirija R, Zheng J, Ludwig K, Xu H, Lazar J, et al. Food intake and interdigestive gastrointestinal motility in ghrelin receptor mutant rats. $J$ Gastroenterol. 2011:46(4):469-78.

164. MacKay H, Charbonneau VR, St-Onge V, Murray E, Watts A, Wellman MK, et al. Rats with a truncated ghrelin receptor (GHSR) do not respond to ghrelin, and show reduced intake of palatable, high-calorie food. Physiol Behav. 2016;163:88-96.

165. Zallar LJ, Tunstall BJ, Richie CT, Zhang YJ, You ZB, Gardner EL, et al. Development and initial characterization of a novel ghrelin receptor CRISPR/Cas9 knockout wistar rat model. Int J Obes. 2019;43(2):344-54. 
166. Tian Y, Yang C, Shang S, Cai Y, Deng X, Zhang J, et al. Loss of FMRP impaired hippocampal long-term plasticity and spatial learning in rats. Front Mol Neurosci. 2017;10:269.

167. Berzhanskaya J, Phillips MA, Shen J, Colonnese MT. Sensory hypo-excitability in a rat model of fetal development in Fragile X Syndrome. Sci Rep. 2016;6: 30769.

168. Golden CEM, Breen MS, Koro L, Sonar S, Niblo K, Browne A, et al. Deletion of the $\mathrm{KH} 1$ domain of Fmr1 leads to transcriptional alterations and attentional deficits in rats. Cereb Cortex. 2019;29(5):2228-44.

169. Kiyozumi D, Nakano I, Takahashi KL, Hojo H, Aoyama H, Sekiguchi K. Fused pulmonary lobes is a rat model of human Fraser syndrome. Biochem Biophys Res Commun. 2011;411(2):440-4.

170. Maichele AJ, Burwinkel B, Maire I, Sovik O, Kilimann MW. Mutations in the testis/liver isoform of the phosphorylase kinase gamma subunit (PHKG2) cause autosomal liver glycogenosis in the gsd rat and in humans. Nat Genet. 1996;14(3):337-40

171. Kuramoto T, Kuwamura M, Tagami F, Mashimo T, Nose M, Serikawa T. Kyoto rhino rats derived by ENU mutagenesis undergo congenital hair loss and exhibit focal glomerulosclerosis. Exp Anim. 2011;60(1):57-63.

172. Nanashima N, Akita M, Yamada T, Shimizu T, Nakano H, Fan Y, et al. The hairless phenotype of the Hirosaki hairless rat is due to the deletion of an 80-kb genomic DNA containing five basic keratin genes. J Biol Chem. 2008; 283(24):16868-75

173. Kuramoto T, Hirano R, Kuwamura M, Serikawa T. Identification of the rat rex mutation as a 7-bp deletion at splicing acceptor site of the Krt71 gene. J Vet Med Sci. 2010;72(7):909-12.

174. Ahearn K, Akkouris G, Berry PR, Chrissluis RR, Crooks IM, Dull AK, et al. The Charles River "hairless" rat mutation maps to chromosome 1: allelic with fuzzy and a likely orthologue of mouse frizzy. J Hered. 2002;93(3):210-3.

175. Spacek DV, Perez AF, Ferranti KM, Wu LK, Moy DM, Magnan DR, et al. The mouse frizzy (fr) and rat 'hairless' (frCR) mutations are natural variants of protease serine S1 family member 8 (Prss8). Exp Dermatol. 2010;19(6):527-32.

176. Asakawa M, Yoshioka T, Matsutani T, Hikita I, Suzuki M, Oshima I, et al. Association of a mutation in TRPV3 with defective hair growth in rodents. J Invest Dermatol. 2006;126(12):2664-72.

177. Bartnikas TB, Wildt SJ, Wineinger AE, Schmitz-Abe K, Markianos K, Cooper $\mathrm{DM}$, et al. A novel rat model of hereditary hemochromatosis due to a mutation in transferrin receptor 2. Comp Med. 2013;63(2):143-55.

178. Booth CJ, Brooks MB, Rockwell S, Murphy JW, Rinder HM, Zelterman D, et al. WAG-F8(m1Ycb) rats harboring a factor VIII gene mutation provide a new animal model for hemophilia A. J Thromb Haemost. 2010;8(11):2472-7.

179. Nielsen LN, Wiinberg B, Hager M, Holmberg HL, Hansen JJ, Roepstorff K, et al. A novel F8 -/- rat as a translational model of human hemophilia A. J Thromb Haemost. 2014;12(8):1274-82.

180. Sorensen KR, Roepstorff K, Wiinberg B, Hansen AK, Tranholm M, Nielsen LN, et al. The F8(-/-) rat as a model of hemophilic arthropathy. J Thromb Haemost. 2016;14(6):1216-25.

181. Shi Q, Mattson JG, Fahs SA, Geurts AM, Weiler H, Montgomery RR. The severe spontaneous bleeding phenotype in a novel hemophilia a rat model is rescued by platelet FVIII expression. Blood Adv. 2020;4(1):55-65.

182. Zhang L, Shao Y, Li L, Tian F, Cen J, Chen X, et al. Efficient liver repopulation of transplanted hepatocyte prevents cirrhosis in a rat model of hereditary tyrosinemia type I. Sci Rep. 2016;6:31460.

183. Shao Y, Wang L, Guo N, Wang S, Yang L, Li Y, et al. Cas9-nickase-mediated genome editing corrects hereditary tyrosinemia in rats. J Biol Chem. 2018; 293(18):6883-92

184. Oiso N, Riddle SR, Serikawa T, Kuramoto T, Spritz RA. The rat Ruby ( R) locus is Rab38: identical mutations in Fawn-hooded and Tester-Moriyama rats derived from an ancestral Long Evans rat sub-strain. Mamm Genome. 2004; 15(4):307-14.

185. Osanai K, Higuchi J, Oikawa R, Kobayashi M, Tsuchihara K, Iguchi M, et al. Altered lung surfactant system in a Rab38-deficient rat model of Hermansky-Pudlak syndrome. Am J Physiol Lung Cell Mol Physiol. 2010; 298(2):L243-51.

186. Emmert AS, Iwasawa E, Shula C, Schultz P, Lindquist D, Dunn RS, et al. Impaired neural differentiation and glymphatic CSF flow in the Ccdc39 rat model of neonatal hydrocephalus: genetic interaction with L1cam. Dis Model Mech. 2019;12(11):dmm040972 https://doi.org/10.1242/dmm.040972.

187. Konishi S, Tanaka N, Mashimo T, Yamamoto T, Sakuma T, Kaneko T, et al. Pathological characteristics of Ccdc85c knockout rats: a rat model of genetic hydrocephalus. Exp Anim. 2020;69(1):26-33.
188. Emmert AS, Vuong SM, Shula C, Lindquist D, Yuan W, Hu YC, et al. Characterization of a novel rat model of X-linked hydrocephalus by CRISPRmediated mutation in L1cam. J Neurosurg. 2019:1-14.

189. Wada M, Toh S, Taniguchi K, Nakamura T, Uchiumi T, Kohno K, et al. Mutations in the canilicular multispecific organic anion transporter (CMOAT) gene, a novel $A B C$ transporter, in patients with hyperbilirubinemia I/DubinJohnson syndrome. Hum Mol Genet. 1998;7(2):203-7.

190. Paulusma CC, Bosma PJ, Zaman GJ, Bakker CT, Otter M, Scheffer GL, et al. Congenital jaundice in rats with a mutation in a multidrug resistanceassociated protein gene. Science. 1996;271(5252):1126-8.

191. Ito K, Suzuki H, Hirohashi T, Kume K, Shimizu T, Sugiyama Y. Molecular cloning of canalicular multispecific organic anion transporter defective in EHBR. Am J Phys. 1997;272(1 Pt 1):G16-22.

192. Ma X, Shang X, Qin X, Lu J, Liu M, Wang X. Characterization of organic anion transporting polypeptide $1 \mathrm{~b} 2$ knockout rats generated by CRISPR/ Cas9: a novel model for drug transport and hyperbilirubinemia disease. Acta Pharm Sin B. 2020;10(5):850-60.

193. Iyanagi T. Molecular basis of multiple UDP-glucuronosyltransferase isoenzyme deficiencies in the hyperbilirubinemic rat (Gunn rat). J Biol Chem. 1991;266(35):24048-52

194. Takahashi M, Ilan Y, Chowdhury NR, Guida J, Horwitz M, Chowdhury JR. Long term correction of bilirubin-UDP-glucuronosyltransferase deficiency in Gunn rats by administration of a recombinant adenovirus during the neonatal period. J Biol Chem. 1996;271(43):26536-42.

195. Zhao Y, Yang Y, Xing R, Cui X, Xiao Y, Xie L, et al. Hyperlipidemia induces typical atherosclerosis development in Ldlr and Apoe deficient rats. Atherosclerosis. 2018;271:26-35.

196. Phillips EH, Chang MS, Gorman S, Qureshi HJ, Ejendal KFK, Kinzer-Ursem TL, et al. Angiotensin infusion does not cause abdominal aortic aneurysms in apolipoprotein E-deficient rats. J Vasc Res. 2018:55:1-12.

197. Lee JG, Ha CH, Yoon B, Cheong SA, Kim G, Lee DJ, et al. Knockout rat models mimicking human atherosclerosis created by Cpf1-mediated gene targeting. Sci Rep. 2019;9(1):2628

198. Asahina M, Mashimo T, Takeyama M, Tozawa R, Hashimoto T, Takizawa A, et al. Hypercholesterolemia and atherosclerosis in low density lipoprotein receptor mutant rats. Biochem Biophys Res Commun. 2012;418(3):553-8.

199. Wang HY, Quan C, Hu C, Xie B, Du Y, Chen L, et al. A lipidomics study reveals hepatic lipid signatures associating with deficiency of the LDL receptor in a rat model. Biol Open. 2016;5(7):979-86.

200. Asahina M, Haruyama W, Ichida Y, Sakamoto M, Sato M, Imaizumi K. Identification of SMEK2 as a candidate gene for regulation of responsiveness to dietary cholesterol in rats. J Lipid Res. 2009;50(1):41-6.

201. Yu Y, Zhang N, Dong X, Fan N, Wang L, Xu Y, Chen H, Duan W. Uricasedeficient rat is generated with CRISPR/Cas9 technique. Peer J. 2020;8:e8971.

202. Liska F, Gosele C, Rivkin E, Tres L, Cardoso MC, Domaing P, et al. Rat hd mutation reveals an essential role of centrobin in spermatid head shaping and assembly of the head-tail coupling apparatus. Biol Reprod. 2009:81(6):1196-205.

203. Kuramoto T, Yokoe M, Hashimoto R, Hiai H, Serikawa T. A rat model of hypohidrotic ectodermal dysplasia carries a missense mutation in the Edaradd gene. BMC Genet. 2011;12:91.

204. Weber M, Wu T, Meilandt WJ, Dominguez SL, Solanoy HO, Maloney JA, et al. BACE1 across species: a comparison of the in vivo consequences of BACE1 deletion in mice and rats. Sci Rep. 2017:7:44249.

205. Yang J, Yi N, Zhang J, He W, He D, Wu W, et al. Generation and characterization of a hypothyroidism rat model with truncated thyroid stimulating hormone receptor. Sci Rep. 2018;8(1):4004.

206. Jahoda CA, Kljuic A, O'Shaughnessy R, Crossley N, Whitehouse CJ, Robinson $M$, et al. The lanceolate hair rat phenotype results from a missense mutation in a calcium coordinating site of the desmoglein 4 gene. Genomics. 2004; 83(5):747-56

207. Bazzi H, Kljuic A, Christiano AM, Christiano AM, Panteleyev AA. Intragenic deletion in the Desmoglein 4 gene underlies the skin phenotype in the Iffa Credo "hairless" rat. Differentiation. 2004;72(8):450-64.

208. Meyer B, Bazzi H, Zidek V, Musilova A, Pravenec M, Kurtz TW, et al. A spontaneous mutation in the desmoglein 4 gene underlies hypotrichosis in a new lanceolate hair rat model. Differentiation. 2004;72(9-10):541-7.

209. Menoret S, Iscache AL, Tesson L, Remy S, Usal C, Osborn MJ, et al. Characterization of immunoglobulin heavy chain knockout rats. Eur J Immunol. 2010;40(10):2932-41.

210. Osborn MJ, Ma B, Avis S, Binnie A, Dilley J, Yang X, et al. High-affinity lgG antibodies develop naturally in Ig-knockout rats carrying germline human 
IgH/lgkappa/Iglambda loci bearing the rat $\mathrm{CH}$ region. J Immunol. 2013; 190(4):1481-90.

211. Nehls M, Pfeifer D, Schorpp M, Hedrich H, Boehm T. New member of the winged-helix protein family disrupted in mouse and rat nude mutations. Nature. 1994;372(6501):103-7.

212. Segre JA, Nemhauser JL, Taylor BA, Nadeau JH, Lander ES. Positional cloning of the nude locus: genetic, physical, and transcription maps of the region and mutations in the mouse and rat. Genomics. 1995;28(3):549-59.

213. Goto T, Hara H, Nakauchi H, Hochi S, Hirabayashi M. Hypomorphic phenotype of Foxn1 gene-modified rats by CRISPR/Cas9 system. Transgenic Res. 2016;25(4):533-44.

214. Mashimo T, Takizawa A, Kobayashi J, Kunihiro Y, Yoshimi K, Ishida S, et al. Generation and characterization of severe combined immunodeficiency rats. Cell Rep. 2012;2(3):685-94.

215. Beldick SR, Hong J, Altamentova S, Khazaei M, Hundal A, Zavvarian MM, et al. Severe-combined immunodeficient rats can be used to generate a model of perinatal hypoxic-ischemic brain injury to facilitate studies of engrafted human neural stem cells. PLoS One. 2018;13(11):e0208105.

216. Zschemisch NH, Glage S, Wedekind D, Weinstein EJ, Cui X, Dorsch M, et al. Zinc-finger nuclease mediated disruption of Rag1 in the LEW/Ztm rat. BMC Immunol. 2012;13:60

217. Noto FK, Adjan-Steffey V, Tong M, Ravichandran K, Zhang W, Arey A, et al. Sprague Dawley Rag2-null rats created from engineered spermatogonial stem cells are immunodeficient and permissive to human xenografts. Mol Cancer Ther. 2018;17(11):2481-9.

218. He D, Zhang J, Wu W, Yi N, He W, Lu P, et al. A novel immunodeficient rat model supports human lung cancer xenografts. FASEB J. 2019;33(1):140-50.

219. Mashimo T, Takizawa A, Voigt B, Yoshimi K, Hiai H, Kuramoto T, et al. Generation of knockout rats with $X$-linked severe combined immunodeficiency (X-SCID) using zinc-finger nucleases. PLoS One. 2010;5(1): e8870.

220. Menoret S, Ouisse LH, Tesson L, Delbos F, Garnier D, Remy S, et al. Generation of Immunodeficient rats with Rag1 and II2rg gene deletions and human tissue grafting models. Transplantation. 2018;102(8):1271-8.

221. Abdul-Majeed S, Mell B, Nauli SM, Joe B. Cryptorchidism and infertility in rats with targeted disruption of the Adamts16 locus. PLoS One. 2014;9(7): e100967.

222. Yarbrough WG, Quarmby VE, Simental JA, Joseph DR, Sar M, Lubahn DB, et al. A single base mutation in the androgen receptor gene causes androgen insensitivity in the testicular feminized rat. J Biol Chem. 1990;265(15):8893900.

223. Ebihara C, Ebihara K, Aizawa-Abe M, Mashimo T, Tomita T, Zhao M, et al. Seipin is necessary for normal brain development and spermatogenesis in addition to adipogenesis. Hum Mol Genet. 2015;24(15):4238-49.

224. Zhang C, Zhou Y, Xie S, Yin Q, Tang C, Ni Z, et al. CRISPR/Cas9-mediated genome editing reveals the synergistic effects of beta-defensin family members on sperm maturation in rat epididymis. FASEB J. 2018;32(3):135463.

225. Kawai Y, Noguchi J, Akiyama K, Takeno Y, Fujiwara Y, Kajita S, et al. A missense mutation of the Dhh gene is associated with male pseudohermaphroditic rats showing impaired Leydig cell development. Reproduction. 2011;141(2):217-25.

226. Rumi MA, Dhakal P, Kubota K, Chakraborty D, Lei T, Larson MA, et al. Generation of Esr1-knockout rats using zinc finger nuclease-mediated genome editing. Endocrinology. 2014;155(5):1991-9.

227. MAK R, Singh P, Roby KF, Zhao X, Iqbal K, Ratri A, et al. Defining the role of estrogen receptor beta in the regulation of female fertility. Endocrinology. 2017;158(7):2330-43

228. Khristi V, Chakravarthi VP, Singh P, Ghosh S, Pramanik A, Ratri A, et al. ESR2 regulates granulosa cell genes essential for follicle maturation and ovulation. Mol Cell Endocrinol. 2018;474:214-26.

229. Khristi V, Ghosh S, Chakravarthi VP, Wolfe MW, Rumi MAK. Transcriptome data analyses of prostatic hyperplasia in Esr2 knockout rats. Data Brief. 2019; 24:103826.

230. Uenoyama Y, Nakamura S, Hayakawa Y, Ikegami K, Watanabe Y, Deura C, et al. Lack of pulse and surge modes and glutamatergic stimulation of luteinising hormone release in Kiss1 knockout rats. J Neuroendocrinol. 2015; 27(3):187-97.

231. Kobayashi T, Kobayashi H, Goto T, Takashima T, Oikawa M, Ikeda H, et al. Germline development in rat revealed by visualization and deletion of Prdm14. Development. 2020;147(4):dev183798.
232. Liska F, Chylikova B, Janku M, Seda O, Vernerova Z, Pravenec M, et al. Splicing mutation in Sbf1 causes nonsyndromic male infertility in the rat. Reproduction. 2016;152(3):215-23.

233. Ishishita S, Inui T, Matsuda Y, Serikawa T, Kitada K. Infertility associated with meiotic failure in the tremor rat $(\mathrm{tm} / \mathrm{tm})$ is caused by the deletion of spermatogenesis associated 22. Exp Anim. 2013;62(3):219-27.

234. Hayashi I, Hoshiko S, Makabe O, Oh-ishi S. A point mutation of alanine 163 to threonine is responsible for the defective secretion of high molecular weight kininogen by the liver of brown Norway Katholiek rats. J Biol Chem. 1993;268(23):17219-24.

235. Kaschina E, Stoll M, Sommerfeld M, Steckelings UM, Kreutz R, Unger T. Genetic kininogen deficiency contributes to aortic aneurysm formation but not to atherosclerosis. Physiol Genomics. 2004;19(1):41-9.

236. Mul JD, Nadra K, Jagalur NB, Nijman IJ, Toonen PW, Medard JJ, et al. A hypomorphic mutation in Lpin1 induces progressively improving neuropathy and lipodystrophy in the rat. J Biol Chem. 2011;286(30):26781-93.

237. Chabod M, Pedros C, Lamouroux L, Colacios C, Bernard I, Lagrange D, et al. A spontaneous mutation of the rat Themis gene leads to impaired function of regulatory T cells linked to inflammatory bowel disease. PLoS Genet. 2012;8(1):e1002461.

238. Shaheen R, Hashem A, Abdel-Salam GM, Al-Fadhli F, Ewida N, Alkuraya FS, Mutations in CIT, encoding citron rho-interacting serine/threonine kinase, cause severe primary microcephaly in humans. Hum Genet. 2016;135(10): $1191-7$.

239. van Boxtel R, Vroling B, Toonen P, Nijman IJ, van Roekel H, Verheul M, et al. Systematic generation of in vivo $\mathrm{G}$ protein-coupled receptor mutants in the rat. Pharmacogenomics J. 2011;11(5):326-36.

240. Marsan E, Ishida S, Schramm A, Weckhuysen S, Muraca G, Lecas S, et al. Depdc5 knockout rat: a novel model of mTORopathy. Neurobiol Dis. 2016; 89:180-9.

241. Kunieda T, Simonaro CM, Yoshida M, Ikadai H, Levan G, Desnick RJ, et al. Mucopolysaccharidosis type $\mathrm{VI}$ in rats: isolation of CDNAs encoding arylsulfatase B, chromosomal localization of the gene, and identification of the mutation. Genomics. 1995;29(3):582-7.

242. Eliyahu E, Wolfson T, Ge Y, Jepsen KJ, Schuchman EH, Simonaro CM. AntiTNF-alpha therapy enhances the effects of enzyme replacement therapy in rats with mucopolysaccharidosis type VI. PLoS One. 2011;6(8):e22447.

243. Yang X, Lu D, Zhang X, Chen W, Gao S, Dong W, et al. Knockout of ISCA1 causes early embryonic death in rats. Animal Model Exp Med. 2019;2(1):18-24.

244. Fan F, Geurts AM, Pabbidi MR, Smith SV, Harder DR, Jacob H, et al. Zincfinger nuclease knockout of dual-specificity protein phosphatase- 5 enhances the myogenic response and autoregulation of cerebral blood flow in FHH.1BN rats. PLoS One. 2014;9(11):e112878.

245. Zigler JS Jr, Hodgkinson CA, Wright M, Klise A, Sundin O, Broman KW, et al. A spontaneous missense mutation in branched chain Keto acid dehydrogenase kinase in the rat affects both the central and peripheral nervous systems. PLoS One. 2016;11(7):e0160447.

246. Xu J, Zhang L, Xie M, Li Y, Huang P, Saunders TL, et al. Role of complement in a rat model of paclitaxel-induced peripheral neuropathy. J Immunol. 2018;200(12):4094-101.

247. Asahina M, Fujinawa R, Nakamura S, Yokoyama K, Tozawa R, Suzuki T. Ngly1 -/- rats develop neurodegenerative phenotypes and pathological abnormalities in their peripheral and central nervous systems. Hum Mol Genet. 2020.

248. Wiedemann T, Bielohuby M, Muller TD, Bidlingmaier M, Pellegata NS. Obesity in MENX rats is accompanied by high circulating levels of ghrelin and improved insulin sensitivity. Diabetes. 2016;65(2):406-20.

249. Aizawa-Abe M, Ebihara K, Ebihara C, Mashimo T, Takizawa A, Tomita T, et al. Generation of leptin-deficient Lepmkyo/Lepmkyo rats and identification of leptin-responsive genes in the liver. Physiol Genomics. 2013;45(17):786-93.

250. Vaira S, Yang C, McCoy A, Keys K, Xue S, Weinstein EJ, et al. Creation and preliminary characterization of a leptin knockout rat. Endocrinology. 2012; 153(11):5622-8.

251. Wu-Peng XS, Chua SC Jr, Okada N, Liu SM, Nicolson M, Leibel RL. Phenotype of the obese Koletsky (f) rat due to Tyr763Stop mutation in the extracellular domain of the leptin receptor (Lepr): evidence for deficient plasma-to-CSF transport of leptin in both the Zucker and Koletsky obese rat. Diabetes. 1997:46(3):513-8.

252. Chua SC Jr, White DW, Wu-Peng XS, Liu SM, Okada N, Kershaw EE, et al. Phenotype of fatty due to GIn269Pro mutation in the leptin receptor (Lepr). Diabetes. 1996;45(8):1141-3. 
253. Bao D, Ma Y, Zhang X, Guan F, Chen W, Gao K, et al. Preliminary characterization of a leptin receptor knockout rat created by CRISPR/Cas9 system. Sci Rep. 2015;5:15942.

254. Mul JD, van Boxtel R, Bergen DJ, Brans MA, Brakkee JH, Toonen PW, et al. Melanocortin receptor 4 deficiency affects body weight regulation, grooming behavior, and substrate preference in the rat. Obesity (Silver Spring). 2012;20(3):612-21.

255. Katayama K, Sasaki T, Goto S, Ogasawara K, Maru H, Suzuki K, et al. Insertional mutation in the Golgb1 gene is associated with osteochondrodysplasia and systemic edema in the OCD rat. Bone. 2011; 49(5):1027-36.

256. Van Wesenbeeck L, Odgren PR, Coxon FP, Frattini A, Moens P, Perdu B, et al. Involvement of PLEKHM1 in osteoclastic vesicular transport and osteopetrosis in incisors absent rats and humans. J Clin Invest. 2007;117(4): 919-30

257. Ubels JL, Diegel CR, Foxa GE, Ethen NJ, Lensing JN, Madaj ZB, et al. Lowdensity lipoprotein receptor-related protein 5 (LRP5)-deficient rats have reduced bone mass and abnormal development of the retinal vasculature. bioRxiv. 2020

258. Baptista MA, Dave KD, Frasier MA, Sherer TB, Greeley M, Beck MJ, et al. Loss of leucine-rich repeat kinase 2 (LRRK2) in rats leads to progressive abnormal phenotypes in peripheral organs. PLoS One. 2013;8(11):e80705.

259. Ness D, Ren Z, Gardai S, Sharpnack D, Johnson VJ, Brennan RJ, et al. Leucine-rich repeat kinase 2 (LRRK2)-deficient rats exhibit renal tubule injury and perturbations in metabolic and immunological homeostasis. PLoS One. 2013;8(6):e66164.

260. Rouillard C, Baillargeon J, Paquet B, St-Hilaire M, Maheux J, Levesque C, et al. Genetic disruption of the nuclear receptor Nur77 ( $\mathrm{Nr4a1)}$ in rat reduces dopamine cell loss and I-Dopa-induced dyskinesia in experimental Parkinson's disease. Exp Neurol. 2018;304:143-53.

261. Sun J, Kouranova E, Cui X, Mach RH, Xu J. Regulation of dopamine presynaptic markers and receptors in the striatum of DJ-1 and Pink 1 knockout rats. Neurosci Lett. 2013;557 Pt B:123-8.

262. Dave KD, De Silva S, Sheth NP, Ramboz S, Beck MJ, Quang C, et al. Phenotypic characterization of recessive gene knockout rat models of Parkinson's disease. Neurobiol Dis. 2014;70:190-203.

263. Villeneuve LM, Purnell PR, Boska MD, Fox HS. Early expression of Parkinson's disease-related mitochondrial abnormalities in PINK1 knockout rats. Mol Neurobiol. 2016;53(1):171-86

264. Guatteo E, Rizzo FR, Federici M, Cordella A, Ledonne A, Latini L, et al. Functional alterations of the dopaminergic and glutamatergic systems in spontaneous alpha-synuclein overexpressing rats. Exp Neurol. 2017;287(Pt 1):21-33.

265. Stoica G, Lungu G, Bjorklund NL, Taglialatela G, Zhang X, Chiu V, et al. Potential role of alpha-synuclein in neurodegeneration: studies in a rat animal model. J Neurochem. 2012;122(4):812-22.

266. Kuramoto T, Gohma H, Kimura K, Wedekind D, Hedrich HJ, Serikawa T. The rat pink-eyed dilution (p) mutation: an identical intragenic deletion in pinkeye dilute-coat strains and several Wistar-derived albino strains. Mamm Genome. 2005;16(9):712-9.

267. Brown JH, Bihoreau MT, Hoffmann S, Kranzlin B, Tychinskaya I, Obermuller N, et al. Missense mutation in sterile alpha motif of novel protein SamCystin is associated with polycystic kidney disease in (cy/+) rat. J Am Soc Nephrol. 2005;16(12):3517-26.

268. Neudecker S, Walz R, Menon K, Maier E, Bihoreau MT, Obermuller N, et al. Transgenic overexpression of Anks6(p.R823W) causes polycystic kidney disease in rats. Am J Pathol. 2010;177(6):3000-9.

269. Hoff S, Halbritter J, Epting D, Frank V, Nguyen TM, van Reeuwijk J, et al. ANKS6 is a central component of a nephronophthisis module linking NEK8 to INVS and NPHP3. Nat Genet. 2013:45(8):951-6.

270. McCooke JK, Appels R, Barrero RA, Ding A, Ozimek-Kulik JE, Bellgard MI, et al. A novel mutation causing nephronophthisis in the Lewis polycystic kidney rat localises to a conserved RCC1 domain in Nek8. BMC Genomics. 2012;13:393

271. Arkhipov SN, Potter DL, Geurts AM, Pavlov TS. Knockout of P2rx7 purinergic receptor attenuates cyst growth in a rat model of ARPKD. Am J Physiol Renal Physiol. 2019;317(6):F1649-F55.

272. Ward CJ, Hogan MC, Rossetti S, Walker D, Sneddon T, Wang X, et al. The gene mutated in autosomal recessive polycystic kidney disease encodes a large, receptor-like protein. Nat Genet. 2002;30(3):259-69.
273. Smith UM, Consugar M, Tee L, McKee BM, Maina EN, Whelan S, et al. The transmembrane protein meckelin (MKS3) is mutated in Meckel-Gruber syndrome and the wpk rat. Nat Genet. 2006;38(2):191-6.

274. Liska F, Snajdr P, Sedova L, Seda O, Chylikova B, Slamova P, et al. Deletion of a conserved noncoding sequence in Plzf intron leads to Plzf downregulation in limb bud and polydactyly in the rat. Dev Dyn. 2009;238(3): 673-84.

275. Liska F, Peterkova R, Peterka M, Landa V, Zidek V, Mlejnek P, et al. Targeting of the Plzf gene in the rat by transcription activator-like effector nuclease results in caudal regression syndrome in spontaneously hypertensive rats. PLoS One. 2016;11(10):e0164206.

276. Li Q, Kingman J, van de Wetering K, Tannouri S, Sundberg JP, Uitto J. Abcc6 knockout Rat model highlights the role of liver in PPi homeostasis in pseudoxanthoma Elasticum. J Invest Dermatol. 2017;137(5):1025-32.

277. Yu D, Zhong Y, Li X, Li Y, Li X, Cao J, et al. Generation of TALEN-mediated FH knockout rat model. Oncotarget. 2016;7(38):61656-69.

278. D'Cruz PM, Yasumura D, Weir J, Matthes MT, Abderrahim H, LaVail MM, et al. Mutation of the receptor tyrosine kinase gene Mertk in the retinal dystrophic RCS rat. Hum Mol Genet. 2000;9(4):645-51.

279. Ostergaard E, Duno M, Batbayli M, Vilhelmsen K, Rosenberg T. A novel MERTK deletion is a common founder mutation in the Faroe Islands and is responsible for a high proportion of retinitis pigmentosa cases. Mol Vis. 2011;17:1485-92.

280. Vollrath D, Feng W, Duncan JL, Yasumura D, D'Cruz PM, Chappelow A, et al. Correction of the retinal dystrophy phenotype of the RCS rat by viral gene transfer of Mertk. Proc Natl Acad Sci U S A. 2001;98(22):12584-9.

281. Zhao M, Andrieu-Soler C, Kowalczuk L, Paz Cortes M, Berdugo M, Dernigoghossian $\mathrm{M}$, et al. A new CRB1 rat mutation links Muller glial cells to retinal telangiectasia. J Neurosci. 2015;35(15):6093-106.

282. Yeo JH, Jung BK, Lee H, Baek IJ, Sung YH, Shin HS, et al. Development of a Pde6b gene knockout rat model for studies of degenerative retinal diseases. Invest Ophthalmol Vis Sci. 2019;60(5):1519-26.

283. Patterson KC, Hawkins VE, Arps KM, Mulkey DK, Olsen ML. MeCP2 deficiency results in robust Rett-like behavioural and motor deficits in male and female rats. Hum Mol Genet. 2016;25(24):5514-5.

284. Patterson KC, Hawkins VE, Arps KM, Mulkey DK, Olsen ML. MeCP2 deficiency results in robust Rett-like behavioural and motor deficits in male and female rats. Hum Mol Genet. 2016;25(15):3303-20.

285. Wu Y, Zhong W, Cui N, Johnson CM, Xing H, Zhang S, et al. Characterization of Rett syndrome-like phenotypes in Mecp2-knockout rats. J Neurodev Disord. 2016;8:23.

286. Nishikawa M, Yasuda K, Takamatsu M, Abe K, Okamoto K, Horibe K, et al. Generation of novel genetically modified rats to reveal the molecular mechanisms of vitamin D actions. Sci Rep. 2020;10(1):5677.

287. Chen J, Batta A, Zheng S, Fitzgibbon WR, Ullian ME, Yu H, et al. The missense mutation in $\mathrm{Abcg} 5$ gene in spontaneously hypertensive rats (SHR) segregates with phytosterolemia but not hypertension. BMC Genet. 2005;6: 40.

288. Umeda T, Takashima N, Nakagawa R, Maekawa M, Ikegami S, Yoshikawa T, et al. Evaluation of Pax6 mutant rat as a model for autism. PLoS One. 2010; 5(12):e15500.

289. Matsuo T, Osumi-Yamashita N, Noji S, Ohuchi H, Koyama E, Myokai F, et al. A mutation in the Pax-6 gene in rat small eye is associated with impaired migration of midbrain crest cells. Nat Genet. 1993;3(4):299-304.

290. Abe K, Takamatsu N, Ishikawa K, Tsurumi T, Tanimoto S, Sakurai Y, et al. Novel ENU-induced mutation in Tbx6 causes dominant spondylocostal dysostosis-like vertebral malformations in the rat. PLoS One. 2015;10(6): e0130231.

291. Suzuki H, Ito Y, Shinohara M, Yamashita S, Ichinose S, Kishida A, et al. Gene targeting of the transcription factor Mohawk in rats causes heterotopic ossification of Achilles tendon via failed tenogenesis. Proc Natl Acad Sci U S A. 2016:113(28):7840-5.

292. Northrup E, Zschemisch NH, Eisenblatter R, Glage S, Wedekind D, Cuppen E, et al. The ter mutation in the rat Dnd1 gene initiates gonadal teratomas and infertility in both genders. PLoS One. 2012;7(5):e38001.

293. Asano A, Tsubomatsu K, Jung CG, Sasaki N, Agui T. A deletion mutation of the protein tyrosine phosphatase kappa (Ptprk) gene is responsible for Thelper immunodeficiency (thid) in the LEC rat. Mamm Genome. 2007;18(11): 779-86.

294. Kose H, Sakai T, Tsukumo S, Wei K, Yamada T, Yasutomo K, et al. Maturational arrest of thymocyte development is caused by a deletion in 
the receptor-like protein tyrosine phosphatase kappa gene in LEC rats. Genomics. 2007:89(6):673-7.

295. Van Wesenbeeck L, Odgren PR, MacKay CA, D'Angelo M, Safadi FF, Popoff $\mathrm{SN}$, et al. The osteopetrotic mutation toothless (tl) is a loss-of-function frameshift mutation in the rat Csf1 gene: evidence of a crucial role for CSF-1 in osteoclastogenesis and endochondral ossification. Proc Natl Acad Sci U S A. 2002;99(22):14303-8.

296. Dobbins DE, Sood R, Hashiramoto A, Hansen CT, Wilder RL, Remmers EF. Mutation of macrophage colony stimulating factor (Csf1) causes osteopetrosis in the tl rat. Biochem Biophys Res Commun. 2002;294(5): 1114-20.

297. Taguchi K, Takaku M, Egner PA, Morita M, Kaneko T, Mashimo T, et al. Generation of a new model rat: Nrf2 knockout rats are sensitive to aflatoxin B1 toxicity. Toxicol Sci. 2016;152(1):40-52.

298. Newman ZL, Printz MP, Liu S, Crown D, Breen L, Miller-Randolph S, et al. Susceptibility to anthrax lethal toxin-induced rat death is controlled by a single chromosome 10 locus that includes rNIrp1. PLoS Pathog. 2010;6(5): e1000906.

299. Cirelli KM, Gorfu G, Hassan MA, Printz M, Crown D, Leppla SH, et al. Inflammasome sensor NLRP1 controls rat macrophage susceptibility to toxoplasma gondii. PLoS Pathog. 2014;10(3):e1003927.

300. Kitada K, Akimitsu T, Shigematsu Y, Kondo A, Maihara T, Yokoi N, et al. Accumulation of $\mathrm{N}$-acetyl-L-aspartate in the brain of the tremor rat, a mutant exhibiting absence-like seizure and spongiform degeneration in the central nervous system. J Neurochem. 2000;74(6):2512-9.

301. Nishitani A, Nagayoshi H, Takenaka S, Asano M, Shimizu S, Ohno Y, et al. Involvement of NMDA receptors in tremor expression in Aspa/Hcn1 doubleknockout rats. Exp Anim. 2020; https://doi.org/10.1538/expanim.20-0025.

302. Kuramoto T, Kitada K, Inui T, Sasaki Y, Ito K, Hase T, et al. Attractin/ mahogany/zitter plays a critical role in myelination of the central nervous system. Proc Natl Acad Sci U S A. 2001;98(2):559-64.

303. Kuwamura M, Maeda M, Kuramoto T, Kitada K, Kanehara T, Moriyama M, et al. The myelin vacuolation $(\mathrm{mv})$ rat with a null mutation in the attractin gene. Lab Investig. 2002;82(10):1279-86.

304. Tanaka M, Izawa T, Yamate J, Franklin RJ, Kuramoto T, Serikawa T, et al. The VF rat with abnormal myelinogenesis has a mutation in Dopey1. Glia. 2014; 62(9):1530-42.

305. Kuramoto T, Yokoe M, Kunisawa N, Ohashi K, Miyake T, Higuchi Y, et al. Tremor dominant Kyoto (Trdk) rats carry a missense mutation in the gene encoding the SK2 subunit of small-conductance $\mathrm{Ca}(2+)$-activated $\mathrm{K}(+)$ channel. Brain Res. 1676;2017:38-45.

306. Samanas NB, Commers TW, Dennison KL, Harenda QE, Kurz SG, Lachel CM, et al. Genetic etiology of renal agenesis: fine mapping of Renag1 and identification of kit as the candidate functional gene. PLoS One. 2015;10(2): e0118147.

307. Arab S, Miyazaki A, Hoang Trung H, Yokoe M, Nakagawa Y, Kaneko T, et al. Long terminal repeat insertion in Kit causes unilateral renal agenesis in rats. Transl Regul Sci. 2020;2(1):30-5.

308. Rost S, Fregin A, Ivaskevicius V, Conzelmann E, Hortnagel K, Pelz HJ, et al. Mutations in VKORC1 cause warfarin resistance and multiple coagulation factor deficiency type 2. Nature. 2004;427(6974):537-41.

309. Li T, Chang CY, Jin DY, Lin PJ, Khvorova A, Stafford DW. Identification of the gene for vitamin K epoxide reductase. Nature. 2004;427(6974):541-4.

310. Sasaki N, Hayashizaki Y, Muramatsu M, Matsuda Y, Ando Y, Kuramoto T, et al. The gene responsible for LEC hepatitis, located on rat chromosome 16, is the homolog to the human Wilson disease gene. Biochem Biophys Res Commun. 1994;202(1):512-8.

311. Wu J, Forbes JR, Chen HS, Cox DW. The LEC rat has a deletion in the copper transporting ATPase gene homologous to the Wilson disease gene. Nat Genet. 1994;7(4):541-5.

312. Plaas M, Seppa K, Reimets R, Jagomae T, Toots M, Koppel T, et al. Wfs1deficient rats develop primary symptoms of Wolfram syndrome: insulindependent diabetes, optic nerve atrophy and medullary degeneration. Sci Rep. 2017;7(1):10220.

313. Toots M, Seppa K, Jagomae T, Koppel T, Pallase M, Heinla I, et al. Preventive treatment with liraglutide protects against development of glucose intolerance in a rat model of Wolfram syndrome. Sci Rep. 2018;8(1):10183.

314. Nakagawa H, Matsubara S, Kuriyama M, Yoshidome H, Fujiyama J, Yoshida $\mathrm{H}$, et al. Cloning of rat lysosomal acid lipase cDNA and identification of the mutation in the rat model of Wolman's disease. J Lipid Res. 1995:36(10): 2212-8.
315. Spence JP, Reiter JL, Qiu B, Gu H, Garcia DK, Zhang L, et al. Estrogendependent upregulation of Adcyap1r1 expression in nucleus Accumbens is associated with genetic predisposition of sex-specific QTL for alcohol consumption on rat chromosome 4. Front Genet. 2018;9:513.

316. Zhou Z, Karlsson C, Liang T, Xiong W, Kimura M, Tapocik JD, et al. Loss of metabotropic glutamate receptor 2 escalates alcohol consumption. Proc Natl Acad Sci U S A. 2013;110(42):16963-8.

317. Wood CM, Nicolas CS, Choi SL, Roman E, Nylander I, Fernandez-Teruel A, et al. Prevalence and influence of cys $407^{*} \mathrm{Grm} 2$ mutation in Hannover-derived Wistar rats: $m$ Glu2 receptor loss links to alcohol intake, risk taking and emotional behaviour. Neuropharmacology. 2017;115:128-38.

318. Ding ZM, Ingraham CM, Hauser SR, Lasek AW, Bell RL, McBride WJ. Reduced levels of $\mathrm{mGlu2} 2$ receptors within the Prelimbic cortex are not associated with elevated glutamate transmission or high alcohol drinking. Alcohol Clin Exp Res. 2017;41(11):1896-906.

319. Yong W, Spence JP, Eskay R, Fitz SD, Damadzic R, Lai D, et al. Alcoholpreferring rats show decreased corticotropin-releasing hormone-2 receptor expression and differences in HPA activation compared to alcoholnonpreferring rats. Alcohol Clin Exp Res. 2014;38(5):1275-83.

320. Lo CL, Lossie AC, Liang T, Liu Y, Xuei X, Lumeng L, et al. High resolution genomic scans reveal genetic architecture controlling alcohol preference in bidirectionally selected rat model. PLoS Genet. 2016;12(8):e1006178.

321. Qiu B, Bell RL, Cao Y, Zhang L, Stewart RB, Graves T, et al. Npy deletion in an alcohol non-preferring rat model elicits differential effects on alcohol consumption and body weight. J Genet Genomics. 2016;43(7):421-30.

322. Izumi R, Kusakabe T, Noguchi M, Iwakura $H$, Tanaka T, Miyazawa T, et al. CRISPR/Cas9-mediated Angptl8 knockout suppresses plasma triglyceride concentrations and adiposity in rats. J Lipid Res. 2018;59(9):1575-85.

323. Zhou LB, Zheng YM, Liao WJ, Song L, Meng X, Gong X, et al. MUC1 deficiency promotes nasal epithelial barrier dysfunction in subjects with allergic rhinitis. J Allergy Clin Immunol. 2019;144(6):1716-9.e5.

324. Exner EC, Geurts AM, Hoffmann BR, Casati M, Stodola T, Dsouza NR, et al. Interaction between Mas1 and AT1RA contributes to enhancement of skeletal muscle angiogenesis by angiotensin-(1-7) in Dahl salt-sensitive rats. PLoS One. 2020;15(4):e0232067.

325. Wang $M$, Sips $P$, Khin $E$, Rotival $M$, Sun $X$, Ahmed $R$, et al. Wars2 is a determinant of angiogenesis. Nat Commun. 2016;7:12061.

326. Falak S, Schafer S, Baud A, Hummel O, Schulz H, Gauguier D, et al. Protease inhibitor 15, a candidate gene for abdominal aortic internal elastic lamina ruptures in the rat. Physiol Genomics. 2014;46(12):418-28.

327. Swanberg M, Lidman O, Padyukov L, Eriksson P, Akesson E, Jagodic M, et al. MHC2TA is associated with differential MHC molecule expression and susceptibility to rheumatoid arthritis, multiple sclerosis and myocardial infarction. Nat Genet. 2005;37(5):486-94.

328. Lorentzen JC, Flornes L, Eklow C, Backdahl L, Ribbhammar U, Guo JP, et al. Association of arthritis with a gene complex encoding C-type lectin-like receptors. Arthritis Rheum. 2007;56(8):2620-32.

329. Rintisch C, Kelkka T, Norin U, Lorentzen JC, Olofsson P, Holmdahl R, Finemapping of the arthritis QTL Pia7 reveals co-localization with Oia2 and the APLEC locus. Genes Immun. 2010;11(3):239-45.

330. Backdahl L, Ekman D, Jagodic M, Olsson T, Holmdahl R. Identification of candidate risk gene variations by whole-genome sequence analysis of four rat strains commonly used in inflammation research. BMC Genomics. 2014; 15:391.

331. Backdahl L, Aoun M, Norin U, Holmdahl R. Identification of Clec $4 b$ as a novel regulator of bystander activation of auto-reactive $T$ cells and autoimmune disease. PLoS Genet. 2020;16(6):e1008788.

332. Liu F, Shen X, Su S, Cui H, Fang Y, Wang T, et al. FcgammaRl-coupled signaling in peripheral nociceptors mediates joint pain in a rat model of rheumatoid arthritis. Arthritis Rheumatol. 2020; https://doi.org/10.1002/art. 41386.

333. Li H, Guan SB, Lu Y, Wang F, Liu YH, Liu QY. Genetic deletion of GIT2 prolongs functional recovery and suppresses chondrocyte differentiation in rats with rheumatoid arthritis. J Cell Biochem. 2018;119(2):1538-47.

334. Li H, Jiang W, Ye S, Zhou M, Liu C, Yang X, et al. P2Y14 receptor has a critical role in acute gouty arthritis by regulating pyroptosis of macrophages. Cell Death Dis. 2020;11(5):394.

335. Laragione T, Brenner M, Lahiri A, Gao E, Harris C, Gulko PS. Huntingtininteracting protein 1 (HIP1) regulates arthritis severity and synovial fibroblast invasiveness by altering PDGFR and Rac1 signalling. Ann Rheum Dis. 2018; 77(11):1627-35. 
336. Hultqvist M, Sareila O, Vilhardt F, Norin U, Olsson LM, Olofsson P, et al. Positioning of a polymorphic quantitative trait nucleotide in the Ncf1 gene controlling oxidative burst response and arthritis severity in rats. Antioxid Redox Signal. 2011;14(12):2373-83.

337. Olofsson P, Holmberg J, Tordsson J, Lu S, Akerstrom B, Holmdahl R. Positional identification of $\mathrm{Ncf} 1$ as a gene that regulates arthritis severity in rats. Nat Genet. 2003;33(1):25-32

338. Yau AC, Tuncel J, Haag S, Norin U, Houtman M, Padyukov L, et al. Conserved 33-kb haplotype in the MHC class III region regulates chronic arthritis. Proc Natl Acad Sci U S A. 2016;113(26):E3716-24.

339. Yau ACY, Tuncel J, Holmdahl R. The major histocompatibility complex class III haplotype Ltab-Ncr3 regulates adjuvant-induced but not antigen-induced autoimmunity. Am J Pathol. 2017;187(5):987-98.

340. Haag S, Tuncel J, Thordardottir S, Mason DE, Yau AC, Dobritzsch D, et al. Positional identification of RT1-B (HLA-DQ) as susceptibility locus for autoimmune arthritis. J Immunol. 2015;194(6):2539-50.

341. Guerreiro-Cacais AO, Norin U, Gyllenberg A, Berglund R, Beyeen AD, Rheumatoid Arthritis Consortium I, et al. VAV1 regulates experimental autoimmune arthritis and is associated with anti-CCP negative rheumatoid arthritis. Genes Immun. 2017;18(1):48-56.

342. Reese RM, Dourado M, Anderson K, Warming S, Stark KL, Balestrini A, et al. Behavioral characterization of a CRISPR-generated TRPA1 knockout rat in models of pain, itch, and asthma. Sci Rep. 2020;10(1):979.

343. Xu Y, Zhao XM, Liu J, Wang YY, Xiong LL, He XY, et al. Complexin I knockout rats exhibit a complex neurobehavioral phenotype including profound ataxia and marked deficits in lifespan. Pflugers Arch. 2020;472(1): 117-33.

344. Serikawa T, Kunisawa N, Shimizu S, Kato M, Alves Iha H, Kinboshi M, et al. Increased seizure sensitivity, emotional defects and cognitive impairment in PHD finger protein 24 (Phf24)-null rats. Behav Brain Res. 2019;369:111922.

345. Regan SL, Hufgard JR, Pitzer EM, Sugimoto C, Hu YC, Williams MT, et al. Knockout of latrophilin-3 in Sprague-Dawley rats causes hyperactivity, hyper-reactivity, under-response to amphetamine, and disrupted dopamine markers. Neurobiol Dis. 2019;130:104494.

346. Regan SL, Cryan MT, Williams MT, Vorhees CV, Ross AE. Enhanced transient striatal dopamine release and reuptake in Lphn3 knockout rats. ACS Chem Neurosci. 2020;11(8):1171-7.

347. Peeters DGA, de Boer SF, Terneusen A, Newman-Tancredi A, Varney MA, Verkes RJ, et al. Enhanced aggressive phenotype of Tph2 knockout rats is associated with diminished 5-HT1A receptor sensitivity. Neuropharmacology. 2019;153:134-41.

348. Schroeder M, Weller A. Anxiety-like behavior and locomotion in CCK1 knockout rats as a function of strain, sex and early maternal environment. Behav Brain Res. 2010:211(2):198-207.

349. Nivard MG, Mbarek H, Hottenga JJ, Smit JH, Jansen R, Penninx BW, et al. Further confirmation of the association between anxiety and CTNND2: replication in humans. Genes Brain Behav. 2014;13(2):195-201.

350. Baud A, Flint J, Fernadez-Teruel A, TRGSM C. Identification of genetic variants underlying anxiety and multiple sclerosis in heterogeneous stock rats. World J Neurosci. 2014;4:216-24.

351. Olivier JD, Van Der Hart MG, Van Swelm RP, Dederen PJ, Homberg JR, Cremers $\mathrm{T}$, et al. A study in male and female 5-HT transporter knockout rats: an animal model for anxiety and depression disorders. Neuroscience. 2008; 152(3):573-84

352. van der Doelen RHA, Robroch B, Arnoldussen IA, Schulpen M, Homberg JR, Kozicz T. Serotonin and urocortin 1 in the dorsal raphe and EdingerWestphal nuclei after early life stress in serotonin transporter knockout rats. Neuroscience. 2017;340:345-58

353. Rutten K, De Vry J, Bruckmann W, Tzschentke TM. Pharmacological blockade or genetic knockout of the NOP receptor potentiates the rewarding effect of morphine in rats. Drug Alcohol Depend. 2011;114(2-3):253-6.

354. Rizzi A, Molinari S, Marti M, Marzola G, Calo G. Nociceptin/orphanin FQ receptor knockout rats: in vitro and in vivo studies. Neuropharmacology. 2011;60(4):572-9.

355. Esclassan F, Francois J, Phillips KG, Loomis S, Gilmour G. Phenotypic characterization of nonsocial behavioral impairment in neurexin 1alpha knockout rats. Behav Neurosci. 2015;129(1):74-85.

356. Homberg JR, Olivier JD, VandenBroeke M, Youn J, Ellenbroek AK, Karel P, et al. The role of the dopamine D1 receptor in social cognition: studies using a novel genetic rat model. Dis Model Mech. 2016;9(10):1147-58.
357. Leo D, Sukhanov I, Gainetdinov RR. Novel translational rat models of dopamine transporter deficiency. Neural Regen Res. 2018;13(12):2091-3.

358. Vengeliene V, Bespalov A, Rossmanith M, Horschitz S, Berger S, Relo AL, et al. Towards trans-diagnostic mechanisms in psychiatry: neurobehavioral profile of rats with a loss-of-function point mutation in the dopamine transporter gene. Dis Model Mech. 2017;10(4):451-61.

359. Rasmus KC, O'Neill CE, Bachtell RK, Cooper DC. Cocaine self-administration in rats lacking a functional trpc4 gene. F1000Res. 2013;2:110.

360. Sun H, Fu S, Cui S, Yin X, Sun X, Qi X, et al. Development of a CRISPRSaCas9 system for projection- and function-specific gene editing in the rat brain. Sci Adv. 2020;6(12):eaay6687.

361. Ma L, Chen X, Zhao B, Shi Y, Han F. Enhanced apoptosis and decreased AMPA receptors are involved in deficit in fear memory in Rin1 knockout rats. J Affect Disord. 2020; in press.

362. Scheimann JR, Moloney RD, Mahbod P, Morano RL, Fitzgerald M, Hoskins O, et al. Conditional deletion of glucocorticoid receptors in rat brain results in sex-specific deficits in fear and coping behaviors. Elife. 2019;8:e44672.

363. Barnett BR, Torres-Velazquez M, Yi SY, Rowley PA, Sawin EA, Rubinstein CD, et al. Sex-specific deficits in neurite density and white matter integrity are associated with targeted disruption of exon 2 of the Disc 1 gene in the rat. Transl Psychiatry. 2019;9(1):82.

364. Kisko TM, Braun MD, Michels S, Witt SH, Rietschel M, Culmsee C, et al. Cacna1c haploinsufficiency leads to pro-social 50-kHz ultrasonic communication deficits in rats. Dis Model Mech. 2018;11(6):dmm034116.

365. Braun MD, Kisko TM, Vecchia DD, Andreatini R, Schwarting RKW, Wohr M. Sex-specific effects of Cacna1c haploinsufficiency on object recognition, spatial memory, and reversal learning capabilities in rats. Neurobiol Learn Mem. 2018;155:543-55.

366. Ackermann F, Schink KO, Bruns C, Izsvak Z, Hamra FK, Rosenmund C, et al. Critical role for Piccolo in synaptic vesicle retrieval. Elife. 2019;8:e46629.

367. Falck J, Bruns C, Hoffmann-Conaway S, Straub I, Plautz EJ, Orlando M, et al. Loss of piccolo function in rats induces cerebellar network dysfunction and pontocerebellar hypoplasia type 3-like phenotypes. J Neurosci. 2020;40(14): 2943-59.

368. Golub Y, Schildbach EM, Touma C, Kratz O, Moll GH, von Horsten S, et al. Role of hypothalamus-pituitary-adrenal axis modulation in the stressresilient phenotype of DPP4-deficient rats. Behav Brain Res. 2019;356:243-9.

369. Jeanneteau F, Barrere C, Vos M, De Vries CJM, Rouillard C, Levesque D, et al. The stress-induced transcription factor NR4A1 adjusts mitochondrial function and synapse number in prefrontal cortex. J Neurosci. 2018;38(6): 1335-50.

370. Taylor SB, Taylor AR, Markham JA, Geurts AM, Kanaskie BZ, Koenig Jl. Disruption of the neuregulin 1 gene in the rat alters HPA axis activity and behavioral responses to environmental stimuli. Physiol Behav. 2011;104(2): 205-14.

371. Ferdaus MZ, Xiao B, Ohara $H$, Nemoto $K$, Harada $Y$, Saar K, et al. Identification of Stim 1 as a candidate gene for exaggerated sympathetic response to stress in the stroke-prone spontaneously hypertensive rat. PLOS One. 2014;9(4):e95091.

372. Ohara H, Nabika T. A nonsense mutation of Stim1 identified in stroke-prone spontaneously hypertensive rats decreased the store-operated calcium entry in astrocytes. Biochem Biophys Res Commun. 2016;476(4):406-11.

373. Deruyver Y, Weyne E, Dewulf K, Rietjens R, Pinto S, Van Ranst N, et al. Intravesical activation of the Cation Channel TRPV4 improves bladder function in a rat model for detrusor underactivity. Eur Urol. 2018;74(3):33645

374. Gopalakrishnan K, Kumarasamy S, Abdul-Majeed S, Kalinoski AL, Morgan EE, Gohara AF, et al. Targeted disruption of Adamts16 gene in a rat genetic model of hypertension. Proc Natl Acad Sci U S A. 2012;109(50):20555-9.

375. Joe B, Saad Y, Dhindaw S, Lee NH, Frank BC, Achinike OH, et al. Positional identification of variants of Adamts 16 linked to inherited hypertension. Hum Mol Genet. 2009:18(15):2825-38.

376. Citterio L, Lanzani C, Manunta P, Bianchi G. Genetics of primary hypertension: the clinical impact of adducin polymorphisms. Biochim Biophys Acta. 2010;1802(12):1285-98.

377. Tripodi G, Florio M, Ferrandi M, Modica R, Zimdahl H, Hubner N, et al. Effect of Add1 gene transfer on blood pressure in reciprocal congenic strains of Milan rats. Biochem Biophys Res Commun. 2004;324(2):562-8.

378. Woon PY, Kaisaki PJ, Braganca J, Bihoreau MT, Levy JC, Farrall M, et al. Aryl hydrocarbon receptor nuclear translocator-like (BMAL1) is associated with 
susceptibility to hypertension and type 2 diabetes. Proc Natl Acad Sci U S A. 2007;104(36):14412-7.

379. Rudemiller N, Lund H, Jacob HJ, Geurts AM, Mattson DL, PhysGen Knockout P. CD247 modulates blood pressure by altering T-lymphocyte infiltration in the kidney. Hypertension. 2014;63(3):559-64.

380. Ehret GB, O'Connor AA, Weder A, Cooper RS, Chakravarti A. Follow-up of a major linkage peak on chromosome 1 reveals suggestive QTLs associated with essential hypertension: GenNet study. Eur J Hum Genet. 2009;17(12): 1650-7.

381. Deng AY, deBlois D, Laporte SA, Gelinas D, Tardif JC, Thorin E, et al. Novel pathogenesis of hypertension and diastolic dysfunction caused by M3R (muscarinic cholinergic 3 receptor) signaling. Hypertension. 2018;72(3):75564.

382. Prisco SZ, Prokop JW, Sarkis AB, Yeo NC, Hoffman MJ, Hansen CC, et al. Refined mapping of a hypertension susceptibility locus on rat chromosome 12. Hypertension. 2014;64(4):883-90.

383. Garrett MR, Rapp JP. Defining the blood pressure QTL on chromosome 7 in Dahl rats by a 177-kb congenic segment containing Cyp11b1. Mamm Genome. 2003;14(4):268-73.

384. Low TY, van Heesch S, van den Toorn H, Giansanti P, Cristobal A, Toonen P, et al. Quantitative and qualitative proteome characteristics extracted from in-depth integrated genomics and proteomics analysis. Cell Rep. 2013;5(5): 1469-78.

385. Seda O, Liska F, Pravenec M, Vernerova Z, Kazdova L, Krenova D, et al. Connexin 50 mutation lowers blood pressure in spontaneously hypertensive rat. Physiol Res. 2017;66(1):15-28.

386. Waghulde H, Cheng X, Galla S, Mell B, Cai J, Pruett-Miller SM, et al. Attenuation of microbiotal dysbiosis and hypertension in a CRISPR/Cas9 gene ablation rat model of GPER1. Hypertension. 2018;72(5):1125-32.

387. Mullins LJ, Kenyon CJ, Bailey MA, Conway BR, Diaz ME, Mullins JJ. Mineralocorticoid excess or glucocorticoid insufficiency: renal and metabolic phenotypes in a Rat Hsd1 1b2 knockout model. Hypertension. 2015;66(3): 667-73.

388. Seitz BM, Demireva EY, Xie H, Fink GD, Krieger-Burke T, Burke WM, et al. 5HT does not lower blood pressure in the 5-HT7 knockout rat. Physiol Genomics. 2019;51(7):302-10.

389. Zhou X, Zhang Z, Shin MK, Horwitz SB, Levorse JM, Zhu L, et al. Heterozygous disruption of renal outer medullary potassium channel in rats is associated with reduced blood pressure. Hypertension. 2013;62(2):288-94.

390. Palygin O, Levchenko V, llatovskaya DV, Pavlov TS, Pochynyuk OM, Jacob HJ, et al. Essential role of Kir5.1 channels in renal salt handling and blood pressure control. JCl Insight. 2017;2(18):e92331.

391. Feng D, Yang C, Geurts AM, Kurth T, Liang M, Lazar J, et al. Increased expression of $\mathrm{NAD}(\mathrm{P}) \mathrm{H}$ oxidase subunit p67(phox) in the renal medulla contributes to excess oxidative stress and salt-sensitive hypertension. Cell Metab. 2012;15(2):201-8.

392. Zheleznova NN, Yang C, Cowley AW Jr. Role of Nox4 and p67phox subunit of Nox2 in ROS production in response to increased tubular flow in the mTAL of Dahl salt-sensitive rats. Am J Physiol Renal Physiol. 2016;311(2): F450-8.

393. Cowley AW Jr, Yang C, Zheleznova NN, Staruschenko A, Kurth T, Rein L, et al. Evidence of the importance of Nox4 in production of hypertension in dahl salt-sensitive rats. Hypertension. 2016;67(2):440-50.

394. Holditch SJ, Schreiber CA, Nini R, Tonne JM, Peng KW, Geurts A, et al. B-type natriuretic peptide deletion leads to progressive hypertension, associated organ damage, and reduced survival: novel model for human hypertension. Hypertension. 2015;66(1):199-210.

395. Kumarasamy S, Waghulde H, Gopalakrishnan K, Mell B, Morgan E, Joe B. Mutation within the hinge region of the transcription factor $\mathrm{Nr} 2 \mathrm{f2}$ attenuates salt-sensitive hypertension. Nat Commun. 2015;6:6252.

396. Cowley AW Jr, Yang C, Kumar V, Lazar J, Jacob H, Geurts AM, et al. Pappa2 is linked to salt-sensitive hypertension in Dahl S rats. Physiol Genomics. 2016;48(1):62-72.

397. Endres BT, Priestley JR, Palygin O, Flister MJ, Hoffman MJ, Weinberg BD, et al. Mutation of Plekha7 attenuates salt-sensitive hypertension in the rat. Proc Natl Acad Sci U S A. 2014;111(35):12817-22.

398. Mahal Z, Fujikawa K, Matsuo H, Zahid HM, Koike M, Misumi M, et al. Effects of the Prdx2 depletion on blood pressure and life span in spontaneously hypertensive rats. Hypertens Res. 2019;42(5):610-7.

399. Mattson DL, Lund H, Guo C, Rudemiller N, Geurts AM, Jacob H. Genetic mutation of recombination activating gene 1 in Dahl salt-sensitive rats attenuates hypertension and renal damage. Am J Physiol Regul Integr Comp Physiol. 2013;304(6):R407-14.

400. Watts SW, Darios ES, Mullick AE, Garver H, Saunders TL, Hughes ED, et al. The chemerin knockout rat reveals chemerin dependence in female, but not male, experimental hypertension. FASEB J. 2018;32(12):fj201800479.

401. Moreno C, Hoffman M, Stodola TJ, Didier DN, Lazar J, Geurts AM, et al. Creation and characterization of a renin knockout rat. Hypertension. 2011; 57(3):614-9.

402. Raff H, Gehrand A, Bruder ED, Hoffman MJ, Engeland WC, Moreno C. Renin knockout rat: control of adrenal aldosterone and corticosterone synthesis in vitro and adrenal gene expression. Am J Physiol Regul Integr Comp Physiol. 2015;308(1):R73-7.

403. Kumarasamy S, Waghulde $H$, Cheng X, Haller ST, Mell B, Abhijith B, et al. Targeted disruption of regulated endocrine-specific protein ( Resp18) in Dahl SS/Mcw rats aggravates salt-induced hypertension and renal injury. Physiol Genomics. 2018;50(5):369-75.

404. Rudemiller NP, Lund H, Priestley JR, Endres BT, Prokop JW, Jacob HJ, et al. Mutation of SH2B3 (LNK), a genome-wide association study candidate for hypertension, attenuates Dahl salt-sensitive hypertension via inflammatory modulation. Hypertension. 2015;65(5):1111-7.

405. Ely D, Milsted A, Dunphy G, Boehme S, Dunmire J, Hart M, et al. Delivery of sry1, but not sry2, to the kidney increases blood pressure and sns indices in normotensive wky rats. BMC Physiol. 2009;9:10.

406. Liska F, Mancini M, Krupkova M, Chylikova B, Krenova D, Seda O, et al. Plzf as a candidate gene predisposing the spontaneously hypertensive rat to hypertension, left ventricular hypertrophy, and interstitial fibrosis. Am J Hypertens. 2014;27(1):99-106.

407. Liska F, Landa V, Zidek V, Mlejnek P, Silhavy J, Simakova M, et al. Downregulation of Plzf gene ameliorates metabolic and cardiac traits in the spontaneously hypertensive Rat. Hypertension. 2017;69(6):1084-91.

408. Zicha J, Dobesova Z, Zidek V, Silhavy J, Simakova M, Mlejnek P, et al. Pharmacogenetic analysis of captopril effects on blood pressure: possible role of the Ednrb (endothelin receptor type B) candidate gene. Physiol Res. 2014;63(2):263-5.

409. Wang D, Li H, Weir EK, Xu Y, Xu D, Chen Y. Dimethylarginine dimethylaminohydrolase 1 deficiency aggravates monocrotaline-induced pulmonary oxidative stress, pulmonary arterial hypertension and right heart failure in rats. Int J Cardiol. 2019;295:14-20.

410. Lambert M, Capuano V, Boet A, Tesson L, Bertero T, Nakhleh MK, et al. Characterization of Kcnk3-mutated rat, a novel model of pulmonary hypertension. Circ Res. 2019;125(7):678-95.

411. Gao W, Shao R, Zhang X, Liu D, Liu Y, Fa X. Up-regulation of caveolin-1 by DJ-1 attenuates rat pulmonary arterial hypertension by inhibiting TGFbeta/ Smad signaling pathway. Exp Cell Res. 2017;361(1):192-8.

412. Zhao L, Oliver E, Maratou K, Atanur SS, Dubois OD, Cotroneo E, et al. The zinc transporter ZIP12 regulates the pulmonary vascular response to chronic hypoxia. Nature. 2015;524(7565):356-60.

413. Xu D, Guo H, Xu X, Lu Z, Fassett J, Hu X, et al. Exacerbated pulmonary arterial hypertension and right ventricular hypertrophy in animals with loss of function of extracellular superoxide dismutase. Hypertension. 2011;58(2): 303-9.

414. Alzoubi A, Almalouf P, Toba M, O'Neill K, Qian X, Francis M, et al. TRPC4 inactivation confers a survival benefit in severe pulmonary arterial hypertension. Am J Pathol. 2013;183(6):1779-88.

415. Nomoto S, Ohta M, Kanai S, Yoshida Y, Takiguchi S, Funakoshi A, et al. Absence of the cholecystokinin-A receptor deteriorates homeostasis of body temperature in response to changes in ambient temperature. Am J Physiol Regul Integr Comp Physiol. 2004;287(3):R556-61.

416. Takiguchi S, Takata Y, Funakoshi A, Miyasaka K, Kataoka K, Fujimura Y, et al. Disrupted cholecystokinin type-A receptor (CCKAR) gene in OLETF rats. Gene. 1997;197(1-2):169-75.

417. Gu H, Cao Y, Qiu B, Zhou Z, Deng R, Chen Z, et al. Establishment and phenotypic analysis of an Mstn knockout rat. Biochem Biophys Res Commun. 2016;477(1):115-22.

418. Mendias CL, Lynch EB, Gumucio JP, Flood MD, Rittman DS, Van Pelt DW, et al. Changes in skeletal muscle and tendon structure and function following genetic inactivation of myostatin in rats. J Physiol. 2015;593(8):2037-52.

419. Fan Z, Li L, Li X, Zhang M, Zhong Y, Li Y, et al. Generation of an oxoglutarate dehydrogenase knockout rat model and effect of high-fat diet. RSC Adv. 2018:8:16636-44. 
420. Stalvey MS, Havasi V, Tuggle KL, Wang D, Birket S, Rowe SM, et al. Reduced bone length, growth plate thickness, bone content, and IGF-I as a model for poor growth in the CFTR-deficient rat. PLoS One. 2017;12(11):e0188497.

421. Fujii T, Hirota K, Yasoda A, Takizawa A, Morozumi N, Nakamura R, et al. Rats deficient C-type natriuretic peptide suffer from impaired skeletal growth without early death. PLoS One. 2018;13(3):e0194812.

422. Lambert LJ, Challa AK, Niu A, Zhou L, Tucholski J, Johnson MS, et al. Increased trabecular bone and improved biomechanics in an osteocalcinnull rat model created by CRISPR/Cas9 technology. Dis Model Mech. 2016; 9(10):1169-79.

423. Liu E, Sun L, Zhang Y, Wang A, Yan J. Aquaporin4 knockout aggravates early brain injury following subarachnoid hemorrhage through impairment of the glymphatic system in rat brain. Acta Neurochir Suppl. 2020;127:59-64.

424. Chen Z, Liu J, Chen Q, Su M, Lu H, Yang Y, et al. Down-regulation of UBA6 exacerbates brain injury by inhibiting the activation of Notch signaling pathway to promote cerebral cell apoptosis in rat acute cerebral infarction model. Mol Cell Probes. 2020;101612 https://doi.org/10.1016/j.mcp.2020. 101612. Online ahead of print.

425. Cheng X, Waghulde H, Mell B, Smedlund K, Vazquez G, Joe B. Pleiotropic effect of a high resolution mapped blood pressure QTL on tumorigenesis. PLoS One. 2016:11(4):e0153519.

426. Fong LY, Taccioli C, Palamarchuk A, Tagliazucchi GM, Jing R, Smalley K, et al. Abrogation of esophageal carcinoma development in miR-31 knockout rats. Proc Natl Acad Sci U S A. 2020;117(11):6075-85.

427. Smits BM, Haag JD, Rissman Al, Sharma D, Tran A, Schoenborn AA, et al. The gene desert mammary carcinoma susceptibility locus Mcs1a regulates Nr2f1 modifying mammary epithelial cell differentiation and proliferation. PLoS Genet. 2013;9(6):e1003549.

428. denDekker AD, Xu X, Vaughn MD, Puckett AH, Gardner LL, Lambring CJ, et $a$ l. Rat Mcs $1 b$ is concordant to the genome-wide association-identified breast cancer risk locus at human 5q11.2 and MIER3 is a candidate cancer susceptibility gene. Cancer Res. 2012;72(22):6002-12.

429. Xu X, Powell DW, Lambring CJ, Puckett AH, Deschenes L, Prough RA, et al. Human MCS5A1 candidate breast cancer susceptibility gene FBXO10 is induced by cellular stress and correlated with lens epithelium-derived growth factor (LEDGF). Mol Carcinog. 2014;53(4):300-13.

430. Samuelson DJ, Hesselson SE, Aperavich BA, Zan Y, Haag JD, Trentham-DietZ A, et al. Rat Mcs5a is a compound quantitative trait locus with orthologous human loci that associate with breast cancer risk. Proc Natl Acad Sci U S A. 2007;104(15):6299-304.

431. Veillet AL, Haag JD, Remfert JL, Meilahn AL, Samuelson DJ, Gould MN. Mcs5c: a mammary carcinoma susceptibility locus located in a gene desert that associates with tenascin C expression. Cancer Prev Res (Phila). 2011:4(1): 97-106.

432. Henning AN, Haag JD, Smits BM, Gould MN. The non-coding mammary carcinoma susceptibility locus, Mcs5c, regulates Pappa expression via agespecific chromatin folding and allele-dependent DNA methylation. PLoS Genet. 2016;12(8):e1006261.

433. Ren X, Graham JC, Jing L, Mikheev AM, Gao Y, Lew JP, et al. Mapping of Mcs30, a new mammary carcinoma susceptibility quantitative trait locus (QTL30) on rat chromosome 12: identification of fry as a candidate Mcs gene. PLoS One. 2013;8(9):e70930.

434. Coan PM, Barrier M, Alfazema N, Carter RN. Marion de Proce S, Dopico XC, et al. Complement factor $\mathrm{B}$ is a determinant of both metabolic and cardiovascular features of metabolic syndrome. Hypertension. 2017;70(3):624-33.

435. McDermott-Roe C, Ye J, Ahmed R, Sun XM, Serafin A, Ware J, et al. Endonuclease $\mathrm{G}$ is a novel determinant of cardiac hypertrophy and mitochondrial function. Nature. 2011:478(7367):114-8.

436. Petretto E, Sarwar R, Grieve I, Lu H, Kumaran MK, Muckett PJ, et al. Integrated genomic approaches implicate osteoglycin (Ogn) in the regulation of left ventricular mass. Nat Genet. 2008;40(5):546-52.

437. Pravenec M, Kazdova L, Landa V, Zidek V, Mlejnek P, Simakova M, et al. Identification of mutated Srebf1 as a QTL influencing risk for hepatic steatosis in the spontaneously hypertensive rat. Hypertension. 2008:51(1): 148-53

438. Paterson MR, Geurts AM, Kriegel AJ. miR-146b-5p has a sex-specific role in renal and cardiac pathology in a rat model of chronic kidney disease. Kidney Int. 2019;96(6):1332-45.

439. Guo H, Xu D, Kuroki M, Lu Z, Xu X, Geurts A, et al. Kidney failure, arterial hypertension and left ventricular hypertrophy in rats with loss of function mutation of SOD3. Free Radic Biol Med. 2020;152:787-96.
440. Yokoi N, Komeda K, Wang HY, Yano H, Kitada K, Saitoh Y, et al. Cblb is a major susceptibility gene for rat type 1 diabetes mellitus. Nat Genet. 2002; 31(4):391-4

441. Arndt T, Wedekind D, Jorns A, Tsiavaliaris G, Cuppen E, Hedrich HJ, et al. A novel Dock8 gene mutation confers diabetogenic susceptibility in the LEW. 1AR1/Ztm-iddm rat, an animal model of human type 1 diabetes. Diabetologia. 2015;58(12):2800-9.

442. MacMurray AJ, Moralejo DH, Kwitek AE, Rutledge EA, Van Yserloo B, Gohlke $P$, et al. Lymphopenia in the BB rat model of type 1 diabetes is due to a mutation in a novel immune-associated nucleotide (lan)-related gene. Genome Res. 2002;12(7):1029-39.

443. Hornum L, Romer J, Markholst H. The diabetes-prone BB rat carries a frameshift mutation in lan4, a positional candidate of Iddm1. Diabetes. 2002; 51(6):1972-9.

444. Hellquist A, Zucchelli M, Kivinen K, Saarialho-Kere U, Koskenmies S, Widen E, et al. The human GIMAP5 gene has a common polyadenylation polymorphism increasing risk to systemic lupus erythematosus. J Med Genet. 2007:44(5):314-21

445. Cort L, Habib M, Eberwine RA, Hessner MJ, Mordes JP, Blankenhorn EP. Diubiquitin (Ubd) is a susceptibility gene for virus-triggered autoimmune diabetes in rats. Genes Immun. 2014;15(3):168-75.

446. Qaisar N, Lin S, Ryan G, Yang C, Oikemus SR, Brodsky MH, et al. A critical role for the type I interferon receptor in virus-induced autoimmune diabetes in rats. Diabetes. 2017;66(1):145-57.

447. Rosengren AH, Jokubka R, Tojjar D, Granhall C, Hansson O, Li DQ, et al. Overexpression of alpha2A-adrenergic receptors contributes to type 2 diabetes. Science. 2010;327(5962):217-20.

448. Zhou X, Zhang R, Zou Z, Shen X, Xie T, Xu C, et al. Hypoglycaemic effects of glimepiride in sulfonylurea receptor 1 deficient rat. Br J Pharmacol. 2019; 176(3):478-90.

449. Zhou X, Xu C, Zou Z, Shen X, Xie T, Zhang R, et al. aThe characteristics of glucose metabolism in the sulfonylurea receptor 1 knockout rat model. Mol Med. 2019;25(1):2

450. Kanemoto $\mathrm{N}$, Kondo M, Iwanaga T, Hishigaki H, Ono T, Mizoguchi-Miyakita A, et al. Genetic analysis of pancreatic duct hyperplasia in Otsuka LongEvans Tokushima Fatty rats: possible association with a region on rat chromosome 14 that includes the disrupted cholecystokinin-A receptor gene. Pathol Int. 2001;51(3):133-9.

451. Takiguchi S, Takata Y, Takahashi N, Kataoka K, Hirashima T, Kawano K, et al. A disrupted cholecystokinin A receptor gene induces diabetes in obese rats synergistically with ODB1 gene. Am J Phys. 1998;274(2):E265-70.

452. Marion E, Kaisaki PJ, Pouillon V, Gueydan C, Levy JC, Bodson A, et al. The gene INPPL1, encoding the lipid phosphatase SHIP2, is a candidate for type 2 diabetes in rat and man. Diabetes. 2002;51(7):2012-7.

453. Yagil C, Varadi-Levi R, Yagil Y. A novel mutation in the $\mathrm{NADH}$ dehydrogenase (ubiquinone) 1 alpha subcomplex 4 (Ndufa4) gene links mitochondrial dysfunction to the development of diabetes in a rodent model. Dis Model Mech. 2018;11(11):dmm036699.

454. Gumbilai V, Ebihara K, Aizawa-Abe M, Ebihara C, Zhao M, Yamamoto Y, et al. Fat mass reduction with adipocyte hypertrophy and insulin resistance in heterozygous PPARgamma mutant rats. Diabetes. 2016; 65(10):2954-65

455. Watanabe TK, Suzuki M, Yamasaki Y, Okuno $S$, Hishigaki H, Ono $T$, et al. Mutated G-protein-coupled receptor GPR10 is responsible for the hyperphagia/dyslipidaemia/obesity locus of Dmo1 in the OLETF rat. Clin Exp Pharmacol Physiol. 2005;32(5-6):355-66.

456. Zheng $X$, Arias EB, Qi NR, Saunders TL, Cartee GD. In vivo glucoregulation and tissue-specific glucose uptake in female Akt substrate $160 \mathrm{kDa}$ knockout rats. PLoS One. 2020;15(2):e0223340.

457. Chen X, Yan Y, Weng Z, Chen C, Lv M, Lin Q, et al. TAK-875 mitigates $\beta$-cell lipotoxicity-induced metaflammation damage through inhibiting the TLR4NF-kB pathway. J Diabetes Res. 2019;2019:5487962.

458. Tsaih SW, Holl K, Jia S, Kaldunski M, Tschannen M, He H, et al. Identification of a novel gene for diabetic traits in rats, mice, and humans. Genetics. 2014; 198(1):17-29.

459. Spires D, Ilatovskaya DV, Levchenko V, North PE, Geurts AM, Palygin O, et al. Protective role of Trpc6 knockout in the progression of diabetic kidney disease. Am J Physiol Renal Physiol. 2018;315(4):F1091-F7.

460. Camara M, Beyersdorf N, Fischer HJ, Herold MJ, Ip CW, van den Brandt J, et al. CD8(+) T cell help is required for efficient induction of EAE in Lewis rats. J Neuroimmunol. 2013;260(1-2):17-27. 
461. N'Diaye M, Brauner S, Flytzani S, Kular L, Warnecke A, Adzemovic MZ, et al. C-type lectin receptors $\mathrm{Mcl}$ and Mincle control development of multiple sclerosis-like neuroinflammation. J Clin Invest. 2020;130(2):838-52.

462. Stridh $P$, Ruhrmann S, Bergman $P$, Thessen Hedreul M, Flytzani S, Beyeen $A D$, et al. Parent-of-origin effects implicate epigenetic regulation of experimental autoimmune encephalomyelitis and identify imprinted DIk1 as a novel risk gene. PLoS Genet. 2014;10(3):e1004265.

463. Nohra R, Beyeen AD, Guo JP, Khademi M, Sundqvist E, Hedreul MT, et al RGMA and IL21R show association with experimental inflammation and multiple sclerosis. Genes Immun. 2010;11(4):279-93.

464. Jagodic M, Colacios C, Nohra R, Dejean AS, Beyeen AD, Khademi M, et al. A role for VAV1 in experimental autoimmune encephalomyelitis and multiple sclerosis. Sci Transl Med. 2009;1(10):10ra21.

465. Beyeen AD, Adzemovic MZ, Ockinger J, Stridh P, Becanovic K, Laaksonen H, et al. IL-22RA2 associates with multiple sclerosis and macrophage effector mechanisms in experimental neuroinflammation. J Immunol. 2010;185(11): 6883-90.

466. Huberle A, Beyeen AD, Ockinger J, Ayturan M, Jagodic M, de Graaf KL, et al. Advanced intercross line mapping suggests that ncf1 (ean6) regulates severity in an animal model of guillain-barre syndrome. J Immunol. 2009; 182(7):4432-8

467. Powell KL, Cain SM, Ng C, Sirdesai S, David LS, Kyi M, et al. A Cav3.2 T-type calcium channel point mutation has splice-variant-specific effects on function and segregates with seizure expression in a polygenic rat model of absence epilepsy. J Neurosci. 2009;29(2):371-80.

468. Ohno Y, Shimizu S, Tatara A, Imaoku T, Ishii T, Sasa M, et al. Hcn1 is a tremorgenic genetic component in a rat model of essential tremor. PLoS One. 2015;10(5):e0123529.

469. Nishitani A, Kunisawa N, Sugimura T, Sato K, Yoshida Y, Suzuki T, et al. Loss of HCN1 subunits causes absence epilepsy in rats. Brain Res. 2019;1706:209-17.

470. Chen TD, Rotival M, Chiu LY, Bagnati M, Ko JH, Srivastava PK, et al. Identification of Ceruloplasmin as a gene that affects susceptibility to glomerulonephritis through macrophage function. Genetics. 2017;206(2): 1139-51.

471. Aitman TJ, Dong R, Vyse TJ, Norsworthy PJ, Johnson MD, Smith J, et al. Copy number polymorphism in Fcgr3 predisposes to glomerulonephritis in rats and humans. Nature. 2006:439(7078):851-5.

472. Page TH, D'Souza Z, Nakanishi S, Serikawa T, Pusey CD, Aitman TJ, et al. Role of novel rat-specific Fc receptor in macrophage activation associated with crescentic glomerulonephritis. J Biol Chem. 2012;287(8):5710-9.

473. Behmoaras J, Bhangal G, Smith J, McDonald K, Mutch B, Lai PC, et al. Jund is a determinant of macrophage activation and is associated with glomerulonephritis susceptibility. Nat Genet. 2008;40(5):553-9.

474. Kang H, Kerloc'h A, Rotival M, Xu X, Zhang Q, D'Souza Z, et al. Kcnn4 is a regulator of macrophage multinucleation in bone homeostasis and inflammatory disease. Cell Rep. 2014;8(4):1210-24.

475. Kosfeld A, Kreuzer M, Daniel C, Brand F, Schafer AK, Chadt A, et al. Wholeexome sequencing identifies mutations of TBC1D1 encoding a Rab-GTPaseactivating protein in patients with congenital anomalies of the kidneys and urinary tract (CAKUT). Hum Genet. 2016;135(1):69-87.

476. Paglialunga S, Simnett G, Robson $H$, Hoang M, Pillai R, Arkell AM, et al. The Rab-GTPase activating protein, TBC1D1, is critical for maintaining normal glucose homeostasis and beta-cell mass. Appl Physiol Nutr Metab. 2017; 42(6):647-55.

477. Whitfield J, Paglialunga S, Smith BK, Miotto PM, Simnett G, Robson HL, et al. Ablating the protein TBC1D1 impairs contraction-induced sarcolemmal glucose transporter 4 redistribution but not insulin-mediated responses in rats. J Biol Chem. 2017;292(40):16653-64.

478. Monti J, Fischer J, Paskas S, Heinig M, Schulz H, Gosele C, et al. Soluble epoxide hydrolase is a susceptibility factor for heart failure in a rat model of human disease. Nat Genet. 2008:40(5):529-37.

479. Abdelmagid N, Bereczky-Veress B, Guerreiro-Cacais AO, Bergman P, Luhr KM, Bergstrom $T$, et al. The calcitonin receptor gene is a candidate for regulation of susceptibility to herpes simplex type 1 neuronal infection leading to encephalitis in rat. PLoS Pathog. 2012;8(6):e1002753.

480. Bovet-Carmona M, Menigoz A, Pinto S, Tambuyzer T, Krautwald K, Voets T, et al. Disentangling the role of TRPM4 in hippocampus-dependent plasticity and learning: an electrophysiological, behavioral and FMRI approach. Brain Struct Funct. 2018;223(8):3557-76.

481. Bovet-Carmona M, Krautwald K, Menigoz A, Vennekens R, Balschun D, Angenstein F. Low frequency pulse stimulation of Schaffer collaterals in
Trpm4(-/-) knockout rats differently affects baseline BOLD signals in target regions of the right hippocampus but not BOLD responses at the site of stimulation. Neurolmage. 2019;188:347-56.

482. Heinig M, Petretto E, Wallace C, Bottolo L, Rotival M, Lu H, et al. A transacting locus regulates an anti-viral expression network and type 1 diabetes risk. Nature. 2010;467(7314):460-4.

483. Ferguson C, McKay M, Harris RA, Homanics GE. Toll-like receptor 4 (TIr4) knockout rats produced by transcriptional activator-like effector nuclease (TALEN)-mediated gene inactivation. Alcohol. 2013;47(8):595-9.

484. Behmoaras J, Diaz AG, Venda L, Ko JH, Srivastava P, Montoya A, et al. Macrophage epoxygenase determines a profibrotic transcriptome signature. J Immunol. 2015;194(10):4705-16.

485. Alfazema N, Barrier M, de Proce SM, Menzies Rl, Carter R, Stewart K, et al. Camk2n1 is a negative regulator of blood pressure, left ventricular mass, insulin sensitivity, and promotes adiposity. Hypertension. 2019;74(3):687-96.

486. Olona A, Terra X, Ko JH, Grau-Bove C, Pinent M, Ardevol A, et al. Epoxygenase inactivation exacerbates diet and aging-associated metabolic dysfunction resulting from impaired adipogenesis. Mol Metab. 2018;11:1832.

487. Silhavy J, Krijt J, Sokolova J, Zidek V, Mlejnek P, Simakova M, et al. Dissecting the role of Folr1 and Folh1 genes in the pathogenesis of metabolic syndrome in spontaneously hypertensive rats. Physiol Res. 2018;67(4):65762.

488. Pravenec M, Kozich V, Krijt J, Sokolova J, Zidek V, Landa V, et al. Genetic variation in renal expression of folate receptor 1 (Folr1) gene predisposes spontaneously hypertensive rats to metabolic syndrome. Hypertension. 2016:67(2):335-41.

489. Seda O, Krenova D, Oliyarnyk O, Sedova L, Krupkova M, Liska F, et al. Heterozygous connexin 50 mutation affects metabolic syndrome attributes in spontaneously hypertensive rat. Lipids Health Dis. 2016;15(1):199.

490. Houstek J, Hejzlarova K, Vrbacky M, Drahota Z, Landa V, Zidek V, et al. Nonsynonymous variants in $\mathrm{mt}-\mathrm{Nd} 2, \mathrm{mt}-\mathrm{Nd} 4$, and $\mathrm{mt}-\mathrm{Nd} 5$ are linked to effects on oxidative phosphorylation and insulin sensitivity in rat conplastic strains. Physiol Genomics. 2012;44(9):487-94.

491. Pravenec M, Zidek V, Landa V, Mlejnek P, Silhavy J, Simakova M, et al. Mutant Wars2 gene in spontaneously hypertensive rats impairs brown adipose tissue function and predisposes to visceral obesity. Physiol Res. 2017:66(6):917-24.

492. Wang J, Ma MC, Mennie AK, Pettus JM, Xu Y, Lin L, et al. Systems biology with high-throughput sequencing reveals genetic mechanisms underlying the metabolic syndrome in the Lyon hypertensive rat. Circ Cardiovasc Genet. 2015;8(2):316-26

493. Wang Z, Wang L, Zhang Z, Feng L, Song X, Wu J. Apolipoprotein A-IV involves in glucose and lipid metabolism of rat. Nutr Metab (Lond). 2019;16: 41.

494. Khristi V, Ratri A, Ghosh S, Borosha S, Dai E, Chakravarthi VP, et al. Liver transcriptome data of Esr1 knockout male rats reveals altered expression of genes involved in carbohydrate and lipid metabolism. Data Brief. 2019;22: 771-80.

495. Mul JD, Yi CX, van den Berg SA, Ruiter M, Toonen PW, van der Elst MC, et al Pmch expression during early development is critical for normal energy homeostasis. Am J Physiol Endocrinol Metab. 2010;298(3):E477-88.

496. Mul JD, O'Duibhir E, Shrestha YB, Koppen A, Vargovic P, Toonen PW, et al. Pmch-deficiency in rats is associated with normal adipocyte differentiation and lower sympathetic adipose drive. PLoS One. 2013;8(3):e60214.

497. Owen DR, Fan J, Campioli E, Venugopal S, Midzak A, Daly E, et al. TSPO mutations in rats and a human polymorphism impair the rate of steroid synthesis. Biochem J. 2017;474(23):3985-99.

498. Yao X, Verkman AS. Marked central nervous system pathology in CD59 knockout rats following passive transfer of Neuromyelitis optica immunoglobulin G. Acta Neuropathol Commun. 2017;5(1):15.

499. Yu Q, Tan RZ, Gan Q, Zhong X, Wang YQ, Zhou J, et al. A novel rat model of nonalcoholic fatty liver disease constructed through CRISPR/Cas-based hydrodynamic injection. Mol Biotechnol. 2017:59(9-10):365-73.

500. Hu Y, Liu S, Zhu BM. CRISPR/Cas9-induced loss of Keap1 enhances antioxidation in rat adipose-derived mesenchymal stem cells. Front Neurol. 2019;10:1311.

501. Grubinska B, Chen L, Alsaloum M, Rampal N, Matson DJ, Yang C, et al. Rat NaV1.7 loss-of-function genetic model: deficient nociceptive and neuropathic pain behavior with retained olfactory function and intraepidermal nerve fibers. Mol Pain. 2019;15:1744806919881846. 
502. Yee JR, Kenkel W, Caccaviello JC, Gamber K, Simmons P, Nedelman M, et al. Identifying the integrated neural networks involved in capsaicin-induced pain using fMRI in awake TRPV1 knockout and wild-type rats. Front Syst Neurosci. 2015;9:15.

503. Tucker AB, Stocker SD. Hypernatremia-induced vasopressin secretion is not altered in TRPV1-/- rats. Am J Physiol Regul Integr Comp Physiol. 2016; 311(3):R451-6.

504. Westlund KN, Zhang LP, Ma F, Nesemeier R, Ruiz JC, Ostertag EM, et al. A rat knockout model implicates TRPC4 in visceral pain sensation. Neuroscience. 2014;262:165-75

505. Huang F, Wang X, Ostertag EM, Nuwal T, Huang B, Jan YN, et al. TMEM16C facilitates $\mathrm{Na}(+)$-activated $\mathrm{K}+$ currents in rat sensory neurons and regulates pain processing. Nat Neurosci. 2013;16(9):1284-90.

506. Akiyama K, Morita H, Suetsugu S, Kuraba S, Numata Y, Yamamoto Y, et al. Actin -related protein 3 (Arp3) is mutated in proteinuric BUF/Mna rats. Mamm Genome. 2008;19(1):41-50.

507. Rangel-Filho A, Lazar J, Moreno C, Geurts A, Jacob HJ. Rab38 modulates proteinuria in model of hypertension-associated renal disease. J Am Soc Nephrol. 2013;24(2):283-92.

508. Fan F, Geurts AM, Pabbidi MR, Ge Y, Zhang C, Wang S, et al. A mutation in gamma-adducin impairs autoregulation of renal blood flow and promotes the development of kidney disease. J Am Soc Nephrol. 2020;31(4):687-700.

509. Fan F, Pabbidi MR, Ge Y, Li L, Wang S, Mims PN, et al. Knockdown of Add3 impairs the myogenic response of renal afferent arterioles and middle cerebral arteries. Am J Physiol Renal Physiol. 2017;312(6):F971-F81.

510. Yeo NC, O'Meara CC, Bonomo JA, Veth KN, Tomar R, Flister MJ, et al. Shroom3 contributes to the maintenance of the glomerular filtration barrier integrity. Genome Res. 2015;25(1):57-65.

511. Chen CC, Geurts AM, Jacob HJ, Fan F, Roman RJ. Heterozygous knockout of transforming growth factor-beta1 protects Dahl $\mathrm{S}$ rats against high saltinduced renal injury. Physiol Genomics. 2013;45(3):110-8.

512. Schulz A, Muller NV, van de Lest NA, Eisenreich A, Schmidbauer M, Barysenka A, et al. Analysis of the genomic architecture of a complex trait locus in hypertensive rat models links Tmem63c to kidney damage. Elife. 2019;8:e42068

513. Williams JM, Johnson AC, Stelloh C, Dreisbach AW, Franceschini N, Regner $K R$, et al. Genetic variants in Arhgef11 are associated with kidney injury in the Dahl salt-sensitive rat. Hypertension. 2012;60(5):1157-68.

514. Lazar J, O'Meara CC, Sarkis AB, Prisco SZ, Xu H, Fox CS, et al. SORCS1 contributes to the development of renal disease in rats and humans. Physiol Genomics. 2013;45(16):720-8.

515. Westbrook L, Johnson AC, Regner KR, Williams JM, Mattson DL, Kyle PB, et al. Genetic susceptibility and loss of Nr4a1 enhances macrophage-mediated renal injury in CKD. J Am Soc Nephrol. 2014;25(11):2499-510.

516. Wang F, Zhang G, Lu Z, Geurts AM, Usa K, Jacob HJ, et al. Antithrombin III/ SerpinC1 insufficiency exacerbates renal ischemia/reperfusion injury. Kidney Int. 2015;88(4):796-803.

517. Dhande IS, Zhu Y, Kneedler SC, Joshi AS, Hicks MJ, Wenderfer SE, et al. Stim1 polymorphism disrupts immune signaling and creates renal injury in hypertension. J Am Heart Assoc. 2020;9(5):e014142.

518. Rintisch C, Ameri J, Olofsson P, Luthman H, Holmdahl R. Positional cloning of the Igl genes controlling rheumatoid factor production and allergic bronchitis in rats. Proc Natl Acad Sci U S A. 2008;105(37):14005-10.

519. Dai MS, Hall SJ, Vantangoli Policelli MM, Boekelheide K, Spade DJ. Spontaneous testicular atrophy occurs despite normal spermatogonial proliferation in a Tp53 knockout rat. Andrology. 2017;5(6):1141-52.

520. Dhande IS, Kneedler SC, Joshi AS, Zhu Y, Hicks MJ, Wenderfer SE, et al. Germ-line genetic variation in the immunoglobulin heavy chain creates stroke susceptibility in the spontaneously hypertensive rat. Physiol Genomics. 2019;51(11):578-85.

521. Rubattu S, Lee-Kirsch MA, DePaolis P, Giliberti R, Gigante B, Lombardi A, et al. Altered structure, regulation, and function of the gene encoding the atrial natriuretic peptide in the stroke-prone spontaneously hypertensive rat. Circ Res. 1999;85(10):900-5.

522. Rubattu S, Ridker $P$, Stampfer MJ, Volpe M, Hennekens $\mathrm{CH}$, Lindpaintner $\mathrm{K}$. The gene encoding atrial natriuretic peptide and the risk of human stroke. Circulation. 1999;100(16):1722-6.

523. Dhande IS, Kneedler SC, Zhu Y, Joshi AS, Hicks MJ, Wenderfer SE, et al. Natural genetic variation in Stim1 creates stroke in the spontaneously hypertensive rat. Genes Immun. 2020;21(3):182-92.
524. Chang L, Zhang W, Shi S, Peng Y, Wang D, Zhang L, et al. microRNA-195 attenuates neuronal apoptosis in rats with ischemic stroke through inhibiting KLF5-mediated activation of the JNK signaling pathway. Mol Med. 2020;26(1):31.

525. Bai L, Shi G, Ma Y, Zhang L, Guan F, Zhang X, et al. Paraoxonase 1 knockout rats have impaired $T$ cell development at the CD4/CD8 double-negative to double-positive transition stage. Sci Rep. 2018;8(1):14457.

526. Tuncel J, Haag S, Yau AC, Norin U, Baud A, Lonnblom E, et al. Natural polymorphisms in Tap2 influence negative selection and CD4ratioCD8 lineage commitment in the rat. PLoS Genet. 2014;10(2):e1004151.

527. Harrill JA, Hukkanen RR, Lawson M, Martin G, Gilger B, Soldatow V, et al. Knockout of the aryl hydrocarbon receptor results in distinct hepatic and renal phenotypes in rats and mice. Toxicol Appl Pharmacol. 2013;272(2): 503-18.

528. Hunter SR, Vonk A, Mullen Grey AK, Riddick DS. Role of glucocorticoid receptor and Pregnane $\mathrm{X}$ receptor in dexamethasone induction of rat hepatic aryl hydrocarbon receptor nuclear translocator and NADPHcytochrome P450 oxidoreductase. Drug Metab Dispos. 2017;45(2):118-29.

529. Haines C, Chatham LR, Vardy A, Elcombe CR, Foster JR, Lake BG. Comparison of the hepatic and thyroid gland effects of sodium phenobarbital in wild type and constitutive androstane receptor (CAR) knockout rats and pregnenolone-16alpha-carbonitrile in wild type and pregnane X receptor (PXR) knockout rats. Toxicology. 2018;400-401:20-7.

530. Stepp DW, Osakwe CC, Belin de Chantemele EJ, Mintz JD. Vascular effects of deletion of melanocortin-4 receptors in rats. Physiol Rep. 2013;1(6):e00146.

531. Priestley JR, Kautenburg KE, Casati MC, Endres BT, Geurts AM, Lombard JH. The NRF2 knockout rat: a new animal model to study endothelial dysfunction, oxidant stress, and microvascular rarefaction. Am J Physiol Heart Circ Physiol. 2016;310(4):H478-87.

532. Beyer AM, Raffai G, Weinberg BD, Fredrich K, Rodgers MS, Geurts AM, et al. Amelioration of salt-induced vascular dysfunction in mesenteric arteries of dahl salt-sensitive rats by missense mutation of extracellular superoxide dismutase. Am J Physiol Heart Circ Physiol. 2014;306(3):H339-47.

533. Miller B, Palygin O, Rufanova VA, Chong A, Lazar J, Jacob HJ, et al. p66Shc regulates renal vascular tone in hypertension-induced nephropathy. J Clin Invest. 2016;126(7):2533-46.

534. Kaisaki PJ, Delepine M, Woon PY, Sebag-Montefiore L, Wilder SP, Menzel S, et al. Polymorphisms in type II SH2 domain-containing inositol 5phosphatase (INPPL1, SHIP2) are associated with physiological abnormalities of the metabolic syndrome. Diabetes. 2004;53(7):1900-4.

\section{Publisher's Note}

Springer Nature remains neutral with regard to jurisdictional claims in published maps and institutional affiliations.

Ready to submit your research? Choose BMC and benefit from:

- fast, convenient online submission

- thorough peer review by experienced researchers in your field

- rapid publication on acceptance

- support for research data, including large and complex data types

- gold Open Access which fosters wider collaboration and increased citations

- maximum visibility for your research: over $100 \mathrm{M}$ website views per year

At $\mathrm{BMC}$, research is always in progress.

Learn more biomedcentral.com/submission 